\title{
Deep Resistivity Structure of Rainier Mesa-Shoshone Mountain, Nevada Test Site, Nevada
}

By Theodore H. Asch, Brian D. Rodriguez, Jay A. Sampson, Jackie M. Williams, and Maryla Deszcz-Pan

Open-File Report 2006-1356 


\section{U.S. Department of the Interior DIRK KEMPTHORNE, Secretary}

\section{U.S. Geological Survey \\ Mark D. Myers, Director}

\section{U.S. Geological Survey, Reston, Virginia: 2006}

For product and ordering information:

World Wide Web: http://www.usgs.gov/pubprod

Telephone: 1-888-ASK-USGS

For more information on the USGS - the Federal source for science about the Earth,

its natural and living resources, natural hazards, and the environment:

World Wide Web: http://www.usgs.gov

Telephone: 1-888-ASK-USGS

Any use of trade, product, or firm names is for descriptive purposes only and does not imply endorsement by the U.S. Government.

Although this report is in the public domain, permission must be secured from the individual copyright owners to reproduce any copyrighted materials contained within this report.

Suggested citation:

Asch, T.H., Rodriguez, B.D., Sampson, J.A., Williams, J.M., and Deszcz-Pan, 2006, Deep resistivity structure of RainierMesa-Shoshone Mountain, Nevada Test Site, Nevada: USGS Open-File Report 2006-1356, 49 p. 


\section{Contents}

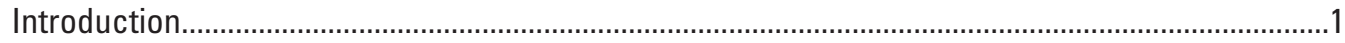

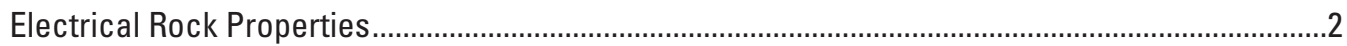

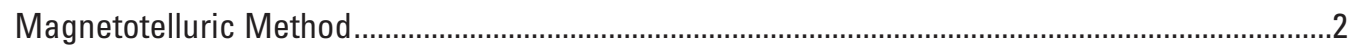

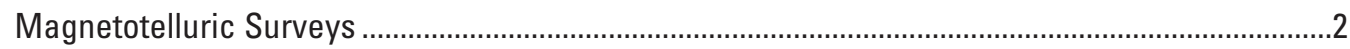

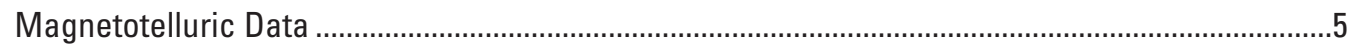

Two-Dimensional Resistivity Modeling ..............................................................................................

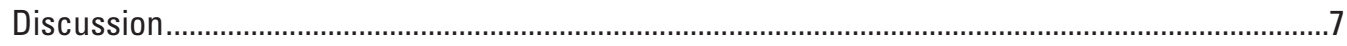

Profile RM1 (Stations RM5-8, YF21-28) ...........................................................................

Profile RM2b (Stations RM13-20, YF44, 46) .............................................................................

Profile RM2d (Stations RM13-20, YF37-42) ........................................................................... 12

Profile RM4 (Stations RM1-4, YF9-14) .................................................................................12

Profile RM6 (Stations RM21-26, YF45-49 .........................................................................13)

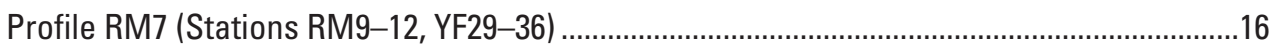

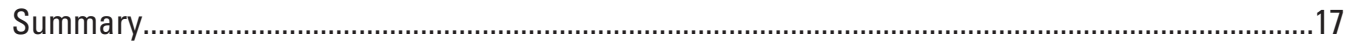

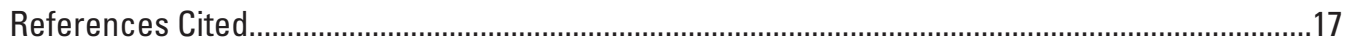

Appendix A

\section{Plates}

1. Schematic geologic image of a portion of the Nevada Test Site illustrating locations of magnetotelluric data acquired in 2005 and some of the 2003 stations used in the numerical analysis and interpretation.

\section{Figures}

1. Schematic image showing magnetotelluric (MT) stations acquired in 2005 in and near Rainier Mesa/Shoshone Mountain, Nevada Test Site, Nevada ..........................1

2. Schematic image showing magnetotelluric (MT) stations grouped into six profiles........5

3. Profile RM1, Model 28 with hydrogeologic interpretation.............................................10

4. Profile RM2b, Model 204 with hydrogeologic interpretation..............................................11

5. Profile RM2d, Model 43 with hydrogeologic interpretation...............................................13

6. Profile RM4, Model 28 with hydrogeologic interpretation .................................................14

7. Profile RM6, Model 57 with hydrogeologic interpretation.................................................15

8. Profile RM7, Model 44 with hydrogeologic interpretation .................................................16

A1. Schematic image showing magnetotelluric (MT) stations in and near Rainier Mesa....21

A2. Profile RM1, 2-D resistivity model 28 - depth section with model mesh. .........................22

A3a. Profile RM1, 2-D resistivity model 28 - observed ...........................................................23

A3b. Profile RM1, 2-D resistivity model 28 - observed ..............................................................24

A4a. Profile RM1, 2-D resistivity model 28 - observed ...............................................................25

A4b. Profile RM1, 2-D resistivity model 28 - observed .............................................................26

A5. Profile RM2b, 2-D resistivity model 204 - depth section with mesh................................27

A6. Profile RM2b, 2-D resistivity model 204 - observed.....................................................28 
A7. Profile RM2b, 2-D resistivity model 204 - observed ..........................................................2

A8. Profile RM2d, 2-D resistivity model 43 - depth section with model mesh ..........................30

A9a. Profile RM2d, 2-D resistivity model 43 - observed..............................................................31

A9b. Profile RM2d, 2-D resistivity model 43 - observed.............................................................32

A10a. Profile RM2d, 2-D resistivity model 43 - observed..........................................................33

A10b. Profile RM2d, 2-D resistivity model 43 - observed..............................................................34

A11. Profile RM4, 2-D resistivity model 28 - depth section with model mesh ...........................35

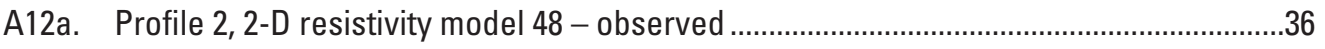

A12b. Profile 2, 2-D resistivity model 48 - observed .....................................................................37

A13a. Profile 2, 2-D resistivity model 48 - observed .................................................................38

A13b. Profile 2, 2-D resistivity model 48 - observed .................................................................39

A14. Profile RM6, 2-D resistivity model 57 - depth section with model mesh ..........................40

A15a. Profile RM6, 2-D resistivity model 57 - observed ............................................................. 41

A15b. Profile RM6, 2-D resistivity model 57 - observed ............................................................42

A16a. Profile RM6, 2-D resistivity model 57- observed ..................................................................

A16b. Profile RM6, 2-D resistivity model 57- observed .............................................................4

A17. Profile RM7, 2-D resistivity model 44 - depth section with model mesh. ..........................45

A18a. Profile RM7, 2-D resistivity model 44 - observed ...........................................................46

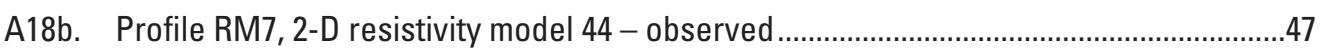

A19a. Profile RM7, 2-D resistivity model 44 - observed .............................................................48

A19b. Profile RM7, 2-D resistivity model 44 - observed.................................................................. 49

\section{Tables}

1a. RM/SM Magnetotelluric station locations. Latitudes and longitudes in WGS 84 (degrees, minutes, seconds) and UTM 11N in NAD83 meters .....

1b. Yucca Flat Magnetotelluric station locations. Latitudes and longitudes in WGS 84 (degrees, minutes, seconds) and UTM 11N in NAD83 meters. Elevations in NGVD29 (meters)

2. MT profile azimuths and angles of rotation applied during processing. $\mathrm{RM}-2005$ Rainier Mesa MT stations; YF - Yucca Flat 2003 MT stations .

3. 2-D inversion (RLM2DI) and forward (PW2D) numerical model meshes for each profile .7

4. Hydrogeologic groups and associated abbreviations .................................................. 


\section{Conversion Factors}

\begin{tabular}{lcl}
\hline Multiply & By & To obtain \\
\hline inch (in.) & 2.54 & centimeter $(\mathrm{cm})$ \\
inch (in.) & 25.4 & millimeter (mm) \\
foot (ft) & 0.3048 & meter (m) \\
mile (mi) & 1.609 & kilometer (km) \\
centimeter (cm) & 0.3937 & inch (in.) \\
millimeter (mm) & 0.03937 & inch (in.) \\
meter (m) & 3.281 & foot (ft) \\
kilometer (km) & 0.6214 & mile (mi) \\
\hline
\end{tabular}

Vertical coordinate information is referenced to the World Geodetic System of 1984 (WGS 84).

Horizontal coordinate information is referenced to the North American Datum of 1983 (NAD 83).

Altitude, as used in this report, refers to distance above the vertical datum. 


\title{
Deep Resistivity Structure of Rainier Mesa-Shoshone Mountain, Nevada Test Site, Nevada
}

\author{
By Theodore H. Asch, Brian D. Rodriguez, Jay A. Sampson, Jackie M. Williams, and Maryla Deszcz-Pan
}

\section{Introduction}

The U. S. Department of Energy (DOE) and the National Nuclear Security Administration (NNSA) at their Nevada Site Office (NSO) are addressing groundwater contamination resulting from historical underground nuclear testing through the Environmental Management (EM) program and, in particular, the Underground Test Area (UGTA) project.

From 1951 to 1992, 828 underground nuclear tests were conducted at the Nevada Test Site northwest of Las Vegas (DOE UGTA Fact Sheet, 2003). Most of these tests were conducted hundreds of feet above the groundwater table; however, more than 200 of the tests were in proximity of, or within, the water table. This underground testing was limited to specific areas of the Nevada Test Site including Pahute Mesa, Rainier Mesa/Shoshone Mountain (RM/SM), Frenchman Flat, and Yucca Flat.

One issue of concern is the nature of the somewhat poorly constrained pre-Tertiary geology and its effects on ground-water flow in the area subsequent to a nuclear test. Ground-water modelers would like to know more about the hydrostratigraphy and geologic structure to support a hydrostratigraphic framework model that is under development for the RM/SM Corrective Action Unit (CAU) (Bechtel Nevada, 2006).

During 2005, the U.S. Geological Survey (USGS), funded by the DOE and NNSA-NSO, collected and processed data from twenty-six Magnetotelluric (MT) and AudioMagnetotelluric (AMT) sites at the Nevada Test Site. Data stations were located in and near Rainier Mesa and Shoshone Mountain to assist in characterizing the pre-Tertiary geology in those areas. These new stations extend to the west the hydrogeologic study that was conducted in Yucca Flat. This work will help to refine the character, thickness, and lateral extent of pre-Tertiary confining units. In particular, a major goal has been to define the upper clastic confining unit (UCCU - late Devonian to Mississippian-age siliciclastic rocks assigned to the Eleana Formation and Chainman Shale(Bechtel Nevada, 2006)) in the Yucca Flat area and west towards Shoshone Mountain in the south, east of Buckboard Mesa, and onto Rainier Mesa in the north. The MT and AMT data have been released in a separate U. S. Geological Survey Open File Report (Williams and others, 2006).
The Nevada Test Site magnetotelluric data interpretation presented in this report includes the results of detailed two-dimensional (2-D) resistivity modeling for each profile (including alternative interpretations) and gross inferences on the three-dimensional (3-D) character of the geology within the region.

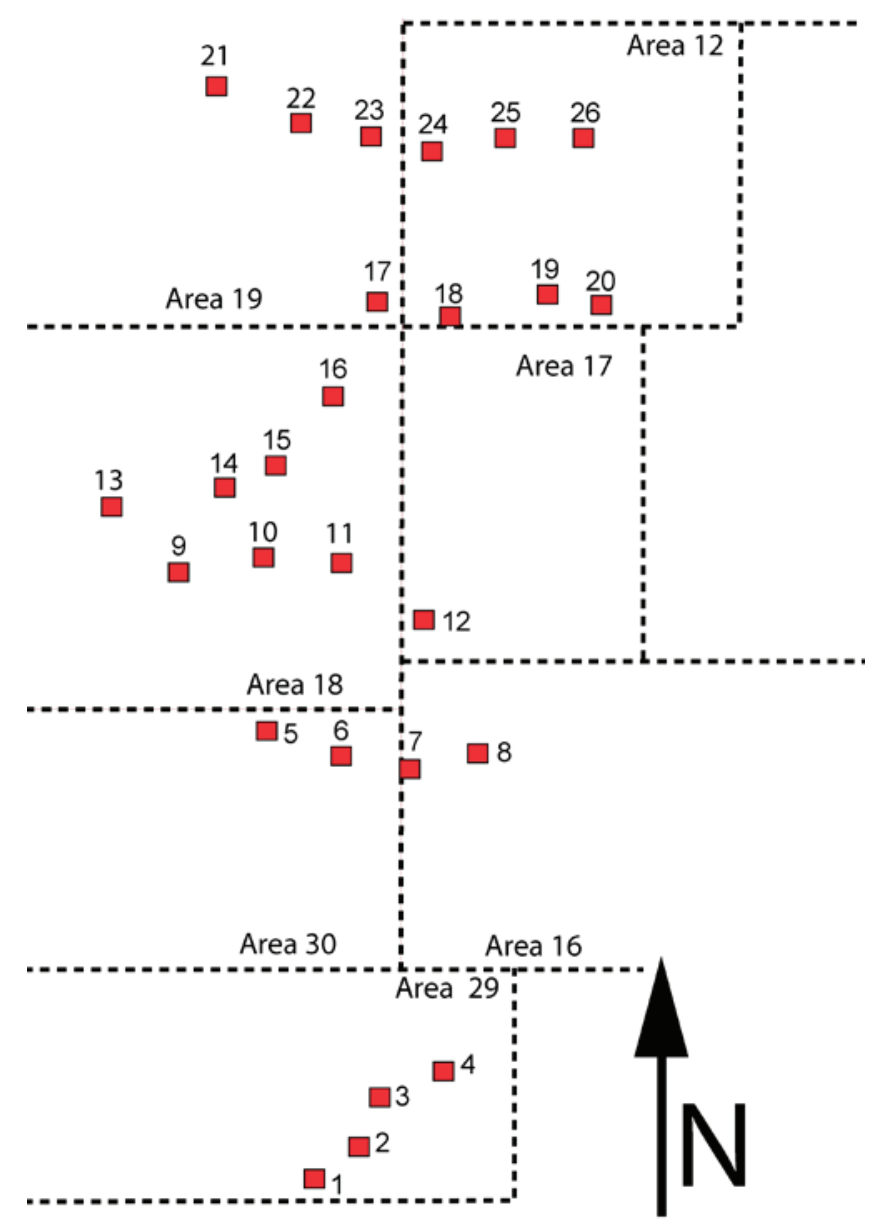

Figure 1. Schematic image showing magnetotelluric (MT) stations in and near Rainier Mesa/Shoshone Mountain, Nevada Test Site, Nevada. MT stations acquired in 2005 are numbered red squares 1-26. Dashed lines are boundaries of Nevada Test Site Areas 12, 16-19, 29, and 30. 


\section{Electrical Rock Properties}

Electromagnetic geophysical methods detect variations in the electrical properties of rocks - in particular, electrical resistivity, or its inverse, electrical conductivity. Electrical resistivity can be correlated with geologic units on the surface and at depth using lithologic logs to provide a three-dimensional picture of subsurface geology. In the upper crust, the resistivities of geologic units are largely dependent upon their fluid content, pore-volume porosity, interconnected fracture porosity, and conductive mineral content (Keller, 1987). While there is not a one-to-one relationship between lithology and resistivity, there are general correlations that can be made using typical values, even though values can be found at other localities that may fall outside of the ranges presented below (Palacky, 1987). Fluids within the pore spaces and fracture openings, especially if saline, can reduce resistivities in what would otherwise be a resistive rock matrix. Resistivity can also be lowered by the presence of electrically conductive clay minerals, graphitic carbon, and metallic mineralization. It is common, for example, for altered volcanic rocks to contain replacement minerals that have resistivities ten times lower than those of the surrounding rocks (Nelson and Anderson, 1992). Fine-grained sediments, such as clay-rich alluvium, marine shales, and other mudstones, are normally conductive, with resistivities ranging from a few ohm-m to a few tens of ohm-m (Keller, 1987; Palacky, 1987). Metamorphic rocks (non-graphitic) and unaltered, unfractured igneous rocks are normally moderately to highly resistive (a few hundreds to thousands of ohm-m). Carbonate rocks can have similarly high resistivities depending on their fluid content, porosity, and impurities (Keller, 1987; Palacky, 1987). Fault zones may be moderately conductive (tens of ohm-m) when comprised of rocks fractured enough to have hosted fluid transport and consequent mineralogical alteration (Eberhart-Phillips and others, 1995). At greater depths, higher subsurface temperatures cause higher ionic mobility that reduces rock resistivities (Keller, 1987; Palacky, 1987). Tables of electrical resistivity for a variety of rocks, minerals and geological environments may be found in Keller (1989) and Palacky (1987).

\section{Magnetotelluric Method}

The MT method is a passive surface geophysical technique that uses the Earth's natural electromagnetic fields to investigate the electrical resistivity structure of the subsurface from depths of tens of meters to tens of kilometers (Vozoff, 1991). Natural variations of the Earth's magnetic and electric field are measured and recorded at each MT station. Worldwide lightning activity at frequencies of 20,000 to 1 Hertz $(\mathrm{Hz})$ and geomagnetic micro-pulsations at frequencies of about 1 to $0.0001 \mathrm{~Hz}$ provide the majority of the signal sensed by the MT method. The natural electromagnetic waves propagate vertically in the Earth because the large resistivity contrast between the air and the Earth causes a vertical refraction of the electromagnetic wave transmitted into the Earth (Vozoff, 1972).

The natural electric and magnetic fields are recorded in two orthogonal, horizontal directions and the vertical magnetic field component is also recorded. The resulting time-series signals are used to derive tensor apparent resistivities and phases by first converting them to complex cross-spectra using Fourier Transform techniques. Then a least-squares, cross-spectral analysis (Bendat and Piersol, 1971) is used to solve for a transfer function that relates the observed electric fields to the observed magnetic fields. Prior to conversion to apparent resistivity and phase, the $2^{\text {nd }}$-rank tensor is normally rotated into directions that contain information on the dimensionality of the subsurface geologic strike. These are usually the principal directions that correspond to the direction of maximum and minimum apparent resistivity. Alternatively, the tensor rotation may be made perpendicular to the survey traverse. For a 2-D Earth, in which the Earth's resistivity structure varies with depth and in one lateral direction, the analysis is simplified. The MT fields can be decoupled into transverse electric (TE) and transverse-magnetic (TM) modes. Twodimensional resistivity modeling is generally computed to fit both modes. When the geology satisfies the 2-D assumption and the MT survey is perpendicular to the geologic strike, the MT data for the TE mode represents the electric field parallel to geologic strike while the data for the TM mode represents the electric field across strike. The MT method is well suited for studying complicated geological environments because the electric and magnetic field transfer functions are sensitive to vertical and horizontal variations in resistivity. The method is capable of establishing whether the electromagnetic fields are responding to subsurface rock bodies of effectively 1, 2, or 3 dimensions. An introduction to the MT method and references for a more advanced understanding are in Dobrin and Savit (1988) and Vozoff (1991).

\section{Magnetotelluric Survey}

Data were collected at 26 stations on and near Rainier Mesa and Shoshone Mountain in May of 2005. The station locations were chosen to help constrain the geologic/hydrostratigraphic interpretation and were selected based on proximity to roads and to avoid, where possible, electrical noise from power lines and vehicles. The low frequency data $(0.0002$ to $200 \mathrm{~Hz}$ ) were collected with an Electromagnetic Instruments, Inc., (EMI) MT24/LF 24-bit system (EMI, 2002), and the high-frequency data $(4 \mathrm{~Hz}$ to $23,000 \mathrm{~Hz}$ ) were collected with a portable EMI MT-1 system (EMI, 1996). For the low frequency data acquisition, horizontal electric fields were measured using three copper-copper sulfate porous-pot electrodes placed in an L-shaped array with dipole lengths of 30 meters (m). Titanium electrodes were used in a similar array for the high-frequency data acquisition. Orthogonal, horizontal magnetic fields collinear with the electric-field measurement array 
were sensed using EMI's high magnetic permeability, mumetal-cored BF-4 (low frequency) and BF-6 (high frequency) induction coils. For the low frequency data, two single-station recordings of the orthogonal, horizontal components of the electric and magnetic fields and the vertical magnetic field were acquired at synchronously Global Positioning System (GPS)-referenced times and were used as remote references for each other (Gamble and others, 1979). The high frequency data were recorded as non-remote referenced single stations.

Table 1 lists the locations of the $25 \mathrm{RM} / \mathrm{SM}$ MT stations (Table 1a) and the 34 Yucca Flat MT stations (Table 1b) used in the combined analysis and interpretation. A Garmin E-Trex GPS was used to record the locations during each site setup. Coordinates are referenced to the 1866 Clarke spheroid and North American 1983 Western United States datum. Longitude and latitude format is degrees, minutes, seconds. Universal Transverse Mercator (UTM) Zone 11 North units are in meters. Station elevation is given in meters (NGVD29). The displayed accuracy of the $x$ and $y$ is about $\pm 5 \mathrm{~m}$ and for the $z$ component is $\pm 10 \mathrm{~m}$. The column labeled "Rotation" refers to rotation of the impedance tensor to either parallel or perpendicular to the profile direction indicated in figure 2. The last column of Table 1 lists the remotely referenced MT site for each station.

Table 1a. RM/SM Magnetotelluric station locations. Latitudes and longitudes in WGS 84 (degrees, minutes, seconds) and UTM 11N in NAD83 meters. Elevations in NGVD29 (meters). Column labeled "Rotation" refers to rotation of the impedance tensor to either parallel or perpendicular to the profile direction. Last column lists the remote reference MT station.

\begin{tabular}{|c|c|c|c|c|c|c|c|}
\hline Stations & Latitude & Longitude & Elevation & UTM 11N North & UTM 11N East & Rotation & Remote \\
\hline 1 & $36^{\circ} 55^{\prime} 28.2^{\prime \prime}$ & $116^{\circ} 16^{\prime} 20.1^{\prime \prime}$ & 1603 & 4086744 & 564819 & Parallel & 5 \\
\hline 2 & $36^{\circ} 56^{\prime} 03.7^{\prime \prime}$ & $116^{\circ} 15^{\prime} 14.9^{\prime \prime}$ & 1729 & 4087851 & 566420 & Parallel & 6 \\
\hline 3 & $36^{\circ} 56^{\prime} 48.6^{\prime \prime}$ & $116^{\circ} 14^{\prime} 52.9^{\prime \prime}$ & 1929 & 4089239 & 566954 & Parallel & 7 \\
\hline 4 & $36^{\circ} 57^{\prime} 15.4^{\prime \prime}$ & $116^{\circ} 13^{\prime} 30.8^{\prime \prime}$ & 1648 & 4090080 & 568979 & Parallel & 8 \\
\hline 5 & $37^{\circ} 04^{\prime} 45.8^{\prime \prime}$ & $116^{\circ} 19^{\prime} 17.8^{\prime \prime}$ & 1454 & 4100906 & 562963 & Parallel & 1 \\
\hline 6 & $37^{\circ} 02^{\prime} 45.2^{\prime \prime}$ & $116^{\circ} 15^{\prime} 42.8^{\prime \prime}$ & 1537 & 4100216 & 565636 & Perpendicular & 2 \\
\hline 7 & $37^{\circ} 02^{\prime} 31.6^{\prime \prime}$ & $116^{\circ} 14^{\prime} 01.8^{\prime \prime}$ & 1665 & 4099819 & 568133 & Parallel & 3 \\
\hline 8 & $37^{\circ} 02^{\prime} 49.1$ "' & $116^{\circ} 12^{\prime} 36.8^{\prime \prime}$ & 1602 & 4100375 & 570229 & Parallel & 4 \\
\hline 9 & $37^{\circ} 05^{\prime} 53.5^{\prime \prime}$ & $116^{\circ} 19^{\prime} 15.2^{\prime \prime}$ & 1521 & 4105982 & 560348 & Perpendicular & 12 \\
\hline 10 & $37^{\circ} 06^{\prime} 05.6^{\prime \prime}$ & $116^{\circ} 17^{\prime} 42.4^{\prime \prime}$ & 1581 & 4106370 & 562632 & Perpendicular & 21 \\
\hline 11 & $37^{\circ} 06^{\prime} 06.1^{\prime \prime}$ & $116^{\circ} 15^{\prime} 48.0^{\prime \prime}$ & 1632 & 4106408 & 565460 & Perpendicular & 17 \\
\hline 12 & $37^{\circ} 05^{\prime} 02.6^{\prime \prime}$ & $116^{\circ} 13^{\prime} 42.5^{\prime \prime}$ & 1640 & 4104474 & 568573 & Perpendicular & 9 \\
\hline 13 & $37^{\circ} 07^{\prime} 04.2^{\prime \prime}$ & $116^{\circ} 20^{\prime} 38.3^{\prime \prime}$ & 1566 & 4108146 & 558283 & Parallel & 22 \\
\hline 14 & $37^{\circ} 07^{\prime} 21.3^{\prime \prime}$ & $116^{\circ} 18^{\prime} 28.3^{\prime \prime}$ & 1578 & 4108693 & 561479 & Parallel & 20 \\
\hline 15 & $37^{\circ} 07^{\prime} 42.9^{\prime \prime}$ & $116^{\circ} 16^{\prime} 33.1^{\prime \prime}$ & 1686 & 4109380 & 564321 & Parallel & 26 \\
\hline 17 & $37^{\circ} 10^{\prime} 33.3^{\prime \prime}$ & $116^{\circ} 14^{\prime} 48.5^{\prime \prime}$ & 1828 & 4114650 & 566860 & Parallel & 11 \\
\hline 18 & $37^{\circ} 09^{\prime} 57.1$ "' & $116^{\circ} 13^{\prime} 35.8^{\prime \prime}$ & 2096 & 4113551 & 568664 & Parallel & 24 \\
\hline 19 & $37^{\circ} 10^{\prime} 31.7^{\prime \prime}$ & $116^{\circ} 11^{\prime} 00.7^{\prime \prime}$ & 1772 & 4114652 & 572478 & Parallel & 23 \\
\hline 20 & $37^{\circ} 10^{\prime} 36.5^{\prime \prime}$ & $116^{\circ} 10^{\prime} 12.5^{\prime \prime}$ & 1867 & 4114810 & 573666 & Parallel & 14 \\
\hline 21 & $37^{\circ} 14^{\prime} 00.6^{\prime \prime}$ & $116^{\circ} 18^{\prime} 23.2^{\prime \prime}$ & 2127 & 4121001 & 561521 & Parallel & 10 \\
\hline 22 & $37^{\circ} 13^{\prime} 30.6^{\prime \prime}$ & $116^{\circ} 16^{\prime} 30.0^{\prime \prime}$ & 2063 & 4120102 & 564318 & Parallel & 13 \\
\hline 23 & $37^{\circ} 13^{\prime} 05.9^{\prime \prime}$ & $116^{\circ} 15^{\prime} 02.1^{\prime \prime}$ & 2097 & 4119357 & 566489 & Parallel & 19 \\
\hline 24 & $37^{\circ} 13^{\prime} 30.7^{\prime \prime}$ & $116^{\circ} 13^{\prime} 19.1^{\prime \prime}$ & 2107 & 4120130 & 569030 & Perpendicular & 18 \\
\hline 25 & $37^{\circ} 13^{\prime} 36.7^{\prime \prime}$ & $116^{\circ} 12^{\prime} 20.6^{\prime \prime}$ & 2059 & 4120333 & 570460 & Parallel & 16 \\
\hline 26 & $37^{\circ} 13^{\prime} 03.8^{\prime \prime}$ & $116^{\circ} 10^{\prime} 37.8^{\prime \prime}$ & 2062 & 4119342 & 573002 & Perpendicular & 15 \\
\hline
\end{tabular}


Table 1b. Yucca Flat Magnetotelluric station locations. Latitudes and longitudes in WGS 84 (degrees, minutes, seconds) and UTM $11 \mathrm{~N}$ in NAD83 meters. Elevations in NGVD29 (meters). Column labeled "Rotation" refers to rotation of the impedance tensor to either parallel or perpendicular to the profile direction. Last column lists the remote reference MT station.

\begin{tabular}{|c|c|c|c|c|c|c|c|}
\hline Stations & Latitude & Longitude & Elevation & UTM 11N North & UTM 11N East & Rotation & Remote \\
\hline 9 & $36^{\circ} 57^{\prime} 36.4^{\prime \prime}$ & $116^{\circ} 12^{\prime} 18.9^{\prime \prime}$ & 1536 & 4090540 & 570753 & Parallel & 46 \\
\hline 10 & $36^{\circ} 58^{\prime} 01.6^{\prime \prime}$ & $116^{\circ} 11^{\prime} 05.3^{\prime \prime}$ & 1437 & 4091331 & 572566 & Parallel & 47 \\
\hline 11 & $36^{\circ} 58^{\prime} 44.4^{\prime \prime}$ & $116^{\circ} 09^{\prime} 53.3^{\prime \prime}$ & 1445 & 4092663 & 574335 & Parallel & 50 \\
\hline 12 & $36^{\circ} 59^{\prime} 36.6^{\prime \prime}$ & $116^{\circ} 08^{\prime} 07.0^{\prime \prime}$ & 1463 & 4094297 & 576949 & Parallel & 49 \\
\hline 13 & $36^{\circ} 59^{\prime} 25.0^{\prime \prime}$ & $116^{\circ} 06^{\prime} 52.1^{\prime \prime}$ & 1335 & 4093950 & 578802 & Parallel & 48 \\
\hline 14 & $36^{\circ} 59^{\prime} 27.5^{\prime \prime}$ & $116^{\circ} 05^{\prime} 36.6^{\prime \prime}$ & 1243 & 4094053 & 580670 & Parallel & $48 \mathrm{a}$ \\
\hline 21 & $37^{\circ} 03^{\prime} 20.9^{\prime \prime}$ & $116^{\circ} 11^{\prime} 12.8^{\prime \prime}$ & 1490 & 4101166 & 572297 & Perpendicular & 44 \\
\hline 22 & $37^{\circ} 04^{\prime} 02.3^{\prime \prime}$ & $116^{\circ} 10^{\prime} 01.1$ " & 1438 & 4102458 & 574055 & Perpendicular & 43 \\
\hline 23 & $37^{\circ} 03^{\prime} 23.6^{\prime \prime}$ & $116^{\circ} 08^{\prime} 16.2^{\prime \prime}$ & 1347 & 4101290 & 576659 & Perpendicular & 37 \\
\hline 24 & $37^{\circ} 03^{\prime} 06.3^{\prime \prime}$ & $116^{\circ} 06^{\prime} 52.0^{\prime \prime}$ & 1306 & 4100781 & 578746 & Perpendicular & 38 \\
\hline 25 & $37^{\circ} 02^{\prime} 54.4^{\prime \prime}$ & $116^{\circ} 05^{\prime} 09.4^{\prime \prime}$ & 1261 & 4100434 & 581280 & Perpendicular & 39 \\
\hline 26 & $37^{\circ} 02^{\prime} 14.0^{\prime \prime}$ & $116^{\circ} 04^{\prime} 05.3^{\prime \prime}$ & 1240 & 4099202 & 582876 & Perpendicular & 40 \\
\hline 27 & $37^{\circ} 01^{\prime} 07.0^{\prime \prime}$ & $116^{\circ} 02^{\prime} 00.7^{\prime \prime}$ & 1209 & 4097167 & 585977 & Perpendicular & 41 \\
\hline 28 & $37^{\circ} 01^{\prime} 06.3^{\prime \prime}$ & $115^{\circ} 59^{\prime} 45.8^{\prime \prime}$ & 1210 & 4097185 & 589311 & Perpendicular & 42 \\
\hline 29 & $37^{\circ} 05^{\prime} 38.3^{\prime \prime}$ & $116^{\circ} 09^{\prime} 55.2^{\prime \prime}$ & 1501 & 4105419 & 574177 & Perpendicular & 17 \\
\hline 30 & $37^{\circ} 04^{\prime} 54.5^{\prime \prime}$ & $116^{\circ} 08^{\prime} 10.0^{\prime \prime}$ & 1367 & 4104092 & 576786 & Parallel & 7 \\
\hline 31 & $37^{\circ} 05^{\prime} 42.2^{\prime \prime}$ & $116^{\circ} 06^{\prime} 51.2^{\prime \prime}$ & 1334 & 4105583 & 578716 & Parallel & None \\
\hline 32 & $37^{\circ} 05^{\prime} 41.0^{\prime \prime}$ & $116^{\circ} 04^{\prime} 57.9^{\prime \prime}$ & 1270 & 4105571 & 581515 & Parallel & None \\
\hline 33 & $37^{\circ} 04^{\prime} 56.9^{\prime \prime}$ & $116^{\circ} 02^{\prime} 58.0^{\prime \prime}$ & 1240 & 4104238 & 584489 & Perpendicular & None \\
\hline 34 & $37^{\circ} 04^{\prime} 07.5^{\prime \prime}$ & $116^{\circ} 01^{\prime} 20.1^{\prime \prime}$ & 1241 & 4102745 & 586922 & Perpendicular & 1 \\
\hline 35 & $37^{\circ} 04^{\prime} 04.8^{\prime \prime}$ & $115^{\circ} 59^{\prime} 59.5^{\prime \prime}$ & 1265 & 4102681 & 588914 & Perpendicular & 19 \\
\hline 36 & $37^{\circ} 04^{\prime} 19.6^{\prime \prime}$ & $115^{\circ} 58^{\prime} 36.3^{\prime \prime}$ & 1327 & 4103157 & 590961 & Perpendicular & 6 \\
\hline 37 & $37^{\circ} 08^{\prime} 26.4^{\prime \prime}$ & $116^{\circ} 08^{\prime} 34.4^{\prime \prime}$ & 1489 & 4110620 & 576125 & Parallel & 23 \\
\hline 38 & $37^{\circ} 08^{\prime} 16.7^{\prime \prime}$ & $116^{\circ} 06^{\prime} 16.5^{\prime \prime}$ & 1331 & 4110353 & 579528 & Parallel & 24 \\
\hline 39 & $37^{\circ} 07^{\prime} 46.8^{\prime \prime}$ & $116^{\circ} 04^{\prime} 18.5^{\prime \prime}$ & 1292 & 4109457 & 582448 & Parallel & 25 \\
\hline 40 & $37^{\circ} 07^{\prime} 23.2^{\prime \prime}$ & $116^{\circ} 02^{\prime} 24.8^{\prime \prime}$ & 1275 & 4108755 & 585262 & Parallel & 26 \\
\hline 41 & $37^{\circ} 07^{\prime} 06.8^{\prime \prime}$ & $116^{\circ} 01^{\prime} 19.1$ " & 1317 & 4108275 & 586891 & Parallel & 27 \\
\hline 42 & $37^{\circ} 06^{\prime} 45.2^{\prime \prime}$ & $115^{\circ} 59^{\prime} 55.7^{\prime \prime}$ & 1373 & 4107623 & 588955 & Parallel & 28 \\
\hline 44 & $37^{\circ} 10^{\prime} 07.6^{\prime \prime}$ & $116^{\circ} 08^{\prime} 00.0^{\prime \prime}$ & 1486 & 4113742 & 576943 & Parallel & 21 \\
\hline 45 & $37^{\circ} 13^{\prime} 13.1^{\prime \prime}$ & $116^{\circ} 08^{\prime} 41.3^{\prime \prime}$ & 1612 & 4119451 & 575875 & Perpendicular & 20 \\
\hline 46 & $37^{\circ} 12^{\prime} 25.4^{\prime \prime}$ & $116^{\circ} 07^{\prime} 13.2^{\prime \prime}$ & 1564 & 4118000 & 578059 & Parallel & 9 \\
\hline 47 & $37^{\circ} 13^{\prime} 35.5^{\prime \prime}$ & $116^{\circ} 04^{\prime} 19.3^{\prime \prime}$ & 1575 & 4120201 & 582325 & Perpendicular & 10 \\
\hline 48 & $37^{\circ} 13^{\prime} 50.6^{\prime \prime}$ & $116^{\circ} 03^{\prime} 39.5^{\prime \prime}$ & 1560 & 4120677 & 583300 & Perpendicular & 13 \\
\hline 49 & $37^{\circ} 13^{\prime} 54.7^{\prime \prime}$ & $116^{\circ} 02^{\prime} 25.7^{\prime \prime}$ & 1486 & 4120819 & 585119 & Perpendicular & 12 \\
\hline
\end{tabular}


Magnetotelluric Data

The recorded time-series data were transformed to the frequency domain and processed to determine a 2-D impedance tensor at each site. Time-series data sets were selected for optimal signal-to-noise characteristics prior to the cross-power calculations. Cross-power files were created with Egbert's (1997) multiple-station, remote-reference magnetotelluric data-processing algorithms. The MT stations were grouped into six (6) sounding profiles (fig. 2) based on acquisition and processing preferences and were named following the 2003 MT profile data nomenclature (Asch and others, 2006). During the analysis and interpretation process, each station was rotated to a fixed angle determined by the given nominal profile orientation or the tipper strike direction depending on the local geologic structure. Rotation of the impedance tensor allows for decoupling into the TE and TM modes. Table 2 lists the nominal line azimuths and the fixed, orthogonal angles of rotation for each profile. Low frequency time-series data were edited with ACQ24, EMI's MT data analysis program to remove noisy data points.

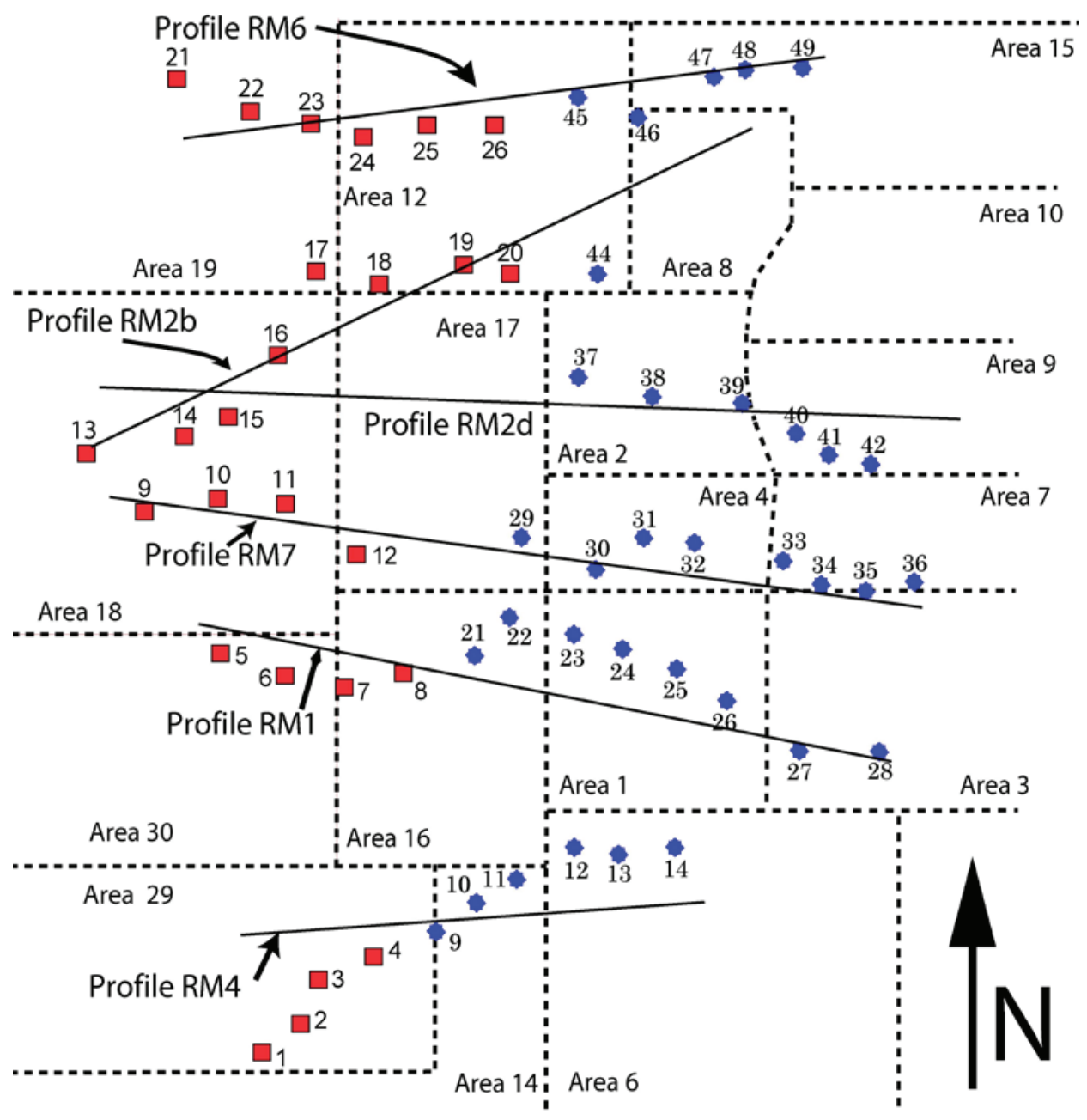

Figure 2. Schematic image showing magnetotelluric (MT) stations in and near Rainier Mesa south to Shoshone Mountain and east to Yucca Flat, Nevada Test Site, Nevada, grouped into six profiles. Approximate azimuth of each profile indicated by solid black lines. MT stations acquired in 2005 are numbered red squares (1-26); 2003 data stations are numbered 9-49 (blue stars). Dashed lines are boundaries of Nevada Test Site Areas 1-4, 6-10, 12-19, 29, and 30. 
Table 2. MT profile azimuths and angles of rotation applied during processing. RM - 2005 Rainier Mesa MT stations; YF - Yucca Flat 2003 MT stations.

\begin{tabular}{|c|c|c|c|}
\hline $\begin{array}{l}\text { Profile } \\
\text { Number }\end{array}$ & $\begin{array}{l}\text { MT Stations in } \\
\text { Profile }\end{array}$ & $\begin{array}{l}\text { Profile Azimuth } \\
\text { (Degrees) }\end{array}$ & $\begin{array}{c}\text { Fixed Angle } \\
\text { of Rotation } \\
\text { (Degrees) }\end{array}$ \\
\hline RM1 & RM 5-8, YF 21-28 & 106 & 16 \\
\hline $\mathrm{RM} 2 \mathrm{~b}$ & RM 13-20, YF 44, 46 & 59 & -31 \\
\hline $\mathrm{RM} 2 \mathrm{~d}$ & RM 13-20, YF 37-42 & 91 & 1 \\
\hline $\mathrm{RM} 4 \mathrm{~b}$ & RM 1-4, YF 9-14 & 87 & -3 \\
\hline RM6b & RM 21-26, YF 45-49 & 81 & -9 \\
\hline RM7b & RM 9-12, YF $29-36$ & 98 & 8 \\
\hline
\end{tabular}

The effects of near-surface resistivity anomalies can cause what are known as "static shifts" in the data (Sternberg and others, 1988). Cultural features also can affect the measured magnetotelluric responses. These include fences, pipelines, communication lines, railways, and other manmade conductors. There were significant static shifts at stations 2, 3, 15, 18, 20, 21 , and 26.

As mentioned above, the raw, field-processed MT data are presented in a separate U.S. Geological Survey Open File Report (Williams and others, 2006). This report included the following plots for each station: Apparent Resistivity, Impedance Phase, Rotation Angle, Impedance Skew, Multiple Coherency, Impedance Polar Plots, Tipper Magnitude, Tipper Strike, and HzHx and HzHy Coherency.

Apparent resistivity is the approximate ratio of the electric-field strength to the magnetic-field strength at a given frequency, which is thus a proxy for depth of exploration. The impedance phase is proportional to the slope of the apparent resistivity curve on a log-log plot, but from baselines at \pm 45 degrees (Vozoff, 1991). A measure of the dimensionality for MT data is provided by the impedance skew of the impedance tensor (Vozoff, 1972). If the effective measured resistivity response to the geology beneath a MT station truly is one or two dimensional, then the skew will be zero. Instrument and environmental sources of electrical noise can cause non-zero skew values. Skew values typically are small (about 0.1 ) for relatively low-noise recordings. Higher skews (above 0.2) are an indication of either the resistivity response to 3-D geology or higher levels of noise. Skew values also tend to increase at lower frequencies as the source magnetotelluric fields average over ever increasing earth volumes. Manmade electrical noise, such as power lines, power generators, and moving vehicles and trains, can have a negative effect on MT data quality. All of these local disturbances can produce incoherent noise that mainly affects frequencies above $1 \mathrm{~Hz}$. Other manmade electrical noise, such as direct current electric trains and active cathodic protection of pipelines, produces coherent electromagnetic signals that mainly affect frequencies below $1 \mathrm{~Hz}$.

In the survey area, noise from a number of small power lines and small moving vehicles was negligible at distances greater than $0.4 \mathrm{~km}$ from the noise source. Power-line signal levels were measured at each site and typically were less than 20 percent of the maximum recordable signals with the exception of station 19, located at the base of Rainier Mesa. Noise from larger power lines, power generators, pipelines, and trains was negligible at distances greater than $5 \mathrm{~km}$. Local lightning, wind, and rainstorms also can degrade data quality. Burying the magnetic induction coils and the electric dipole wires minimized wind noise.

Predicted values of the electric field can be computed from the measured values of the magnetic field (Vozoff, 1991). The coherence of the predicted electric field with the measured electric field is a measure of the signal-to-noise ratio provided in the multiple coherency plots. Values are normalized between 0 and 1 ; values at 0.5 signify signal levels equal to noise levels. For these MT data, coherencies generally were at an acceptable level, except at times in the frequency ranges of 0.01 to $5 \mathrm{~Hz}$ (often referred to as the "dead band").

The field-processed MT data include some scatter and poor signal-to-noise ratios. Spectral results were inspected visually for noisy data, and the best signal-to-noise field data were combined into spectral data sets.

The RM/SM magnetotelluric impedance polar plots (Williams and others, 2006) provide a measure of MT data dimensionality (Reddy and others, 1977). For 1-D resistivity structures, the principal impedance polar diagram is a circle. For 2-D or 3-D resistivity structures, the principal impedance polar diagram elongates either parallel or perpendicular to strike direction. Over resistors, the principal impedance polar diagram elongates perpendicular to strike direction, and over conductors, it elongates parallel to strike direction. For 2-D resistivity structures, the additional impedance polar diagram attains the shape of a symmetric cloverleaf. For 3-D resistivity structures, the impedance polar diagram elongates in one direction and its amplitude is comparable to that of the principal impedance polar diagram.

The magnetotelluric "tipper" is calculated from the vertical component of the magnetic field. The tipper magnitude is a measure of the "tipping" of the magnetic field out of the horizontal plane (Vozoff, 1991). It will be equal to zero for the 1-D case. Typically, the tipper value is between 0.1 to 0.5 and seldom approaches 1.0. The tipper responds primarily to vertical and sub-vertical structures. The tipper magnitude of the stations discussed in this report ranged from 0.1 to 0.6 over the lower frequencies. This indicates some lateral contacts or vertical structure at depth. The tipper strike is further used to help resolve the 90-degree ambiguity in the impedance rotation angle. The $\mathrm{HzHx}$ and $\mathrm{HzHy}$ coherency is 
a measure of the signal-to-noise ratio of the vertical magnetic field with respect to each of the orthogonal, horizontal magnetic field components. Values are normalized between 0 and 1 ; values at 0.5 signify signal levels equal to noise levels. These three-component magnetic-field coherencies provide a check on the signal-to-noise ratio of the measured values in the tipper magnitude and tipper strike.

\section{Two-Dimensional Resistivity Modeling}

A two-dimensional (2-D) modeling analysis of the Rainier Mesa/Shoshone Mountain MT data has been performed. Wannamaker (1983) found that while some MT responses in the Basin and Range region are fundamentally three-dimensional (3-D) in nature, for elongated structures such as are expected based on surface geology, 2-D modeling could be used to construct reasonable estimates of the resistivity cross-sections along each profile. Wannamaker and others (1984) demonstrated that approximating 3-D structure beneath a centrally located profile with 2-D modeling is best achieved when fitting the TM curve even at the expense of a poor fit of the TE curve. However, because TM data are relatively insensitive to the depth extent of a subsurface body (Eberhart-Phillips and others, 1995), the depths to the base of the bodies in the model are not well constrained. Hence, clarifying the model limits with 3 -D resistivity modeling may be necessary.

2-D resistivity models were constructed for each profile using data from both the 2005 Rainier Mesa/Shoshone Mountain MT data set and the 2003 Yucca Flat MT data set. The actual data stations used for each profile are indicated in figure 2. First, 2-D inversions of the TM data were conducted using the computer program, RLM2DI (Mackie and others [1997] and Rodi and Mackie [2001]). This was followed by the application of the 2-D forward modeling algorithm program, PW2D, developed by Wannamaker and others (1987). The results of the RLM2DI 2-D inversion were used as the initial input model for the forward modeling, PW2D, where a sensitivity analysis was performed on the conductive structures derived from the inversion results.

RLM2DI uses a finite-difference network analog to the Maxwell's equations governing magnetotellurics to calculate the forward solution. A non-linear conjugate gradient optimization approach is then applied directly to the minimization of the objective function for the inverse problem. PW2D is a stable finite-element algorithm that simulates transverse electric and magnetic fields using a linear basis across each finite element. The inversion algorithm, RLM2DI, was usually allowed to batch run 25 iterations in order to reduce the Root Mean Squared (RMS) error to a reasonable value between the field data and the numerical model. The number of trial and error forward modeling (PW2D) tests of model features generally depended on how complex the profile inversion results were from RLM2DI.
Table 3 lists the number of horizontal and vertical nodes that were used in the modeling for each profile. The variability in the number of nodes from profile to profile is due to the different number of MT stations along each profile and the length of the profile. In all cases the number of horizontal and vertical nodes necessary for the iterative forward modeling (PW2D) algorithm to accurately model the Rainier Mesa/Shoshone Mountain subsurface resistivity distribution is greater than the number of nodes required by the inversion algorithm (RLM2DI). This is a function of some fundamental differences between how finite-difference and finite-element algorithms handle the numerical boundary conditions and, subsequently, how the electric and magnetic fields are calculated across the mesh.

Table 3. Inversion (RLM2DI) and forward (PW2D) numerical model meshes for each profile. The number of horizontal ("Horiz") nodes and vertical ("Vert") nodes in each model mesh are listed. Nine (9) additional vertical nodes were used to model the overlying air layer.

\begin{tabular}{|c|c|c|c|c|}
\hline Profile & \multicolumn{2}{|c|}{ RLM2DI } & \multicolumn{2}{c|}{ PW2D } \\
\hline No. & Horiz & Vert & Horiz & Vert \\
\hline RM1 & 72 & 59 & 104 & 62 \\
\hline RM2b & 61 & 59 & 93 & 66 \\
\hline RM2d & 85 & 59 & 117 & 65 \\
\hline RM4b & 84 & 59 & 123 & 66 \\
\hline RM6b & 69 & 59 & 98 & 62 \\
\hline RM7b & 87 & 59 & 119 & 62 \\
\hline
\end{tabular}

The edges of the model were extended to over $800-\mathrm{km}$ horizontally and $450-\mathrm{km}$ vertically, so as to assure that the necessary boundary conditions are met. The resolution of the resistivity boundaries used for each model is somewhat subjective. If different resistivities were used, then boundary positions and layer depths would have to be adjusted to achieve similar fits to the observed data. The extreme case would be to use a model with a "continuous" resistivity gradient from low to high resistivities. The resolution of the resistivity boundaries is also, in part, a function of the model grid mesh design. We have attempted to keep each model simple. For each MT profile the model depth is relative to the Earth's surface.

\section{Discussion}

The 2005 NTS magnetotelluric study (pl. 1) was a western extension into volcanic terranes of the Yucca Flat investigation that was initiated in 2003 and so included an examination of the relationship between the younger, shallow volcanic units and the older, deeper carbonate units. The area from Rainier Mesa 
in the north down through Mid Valley to Shoshone Mountain in the south includes many Tertiary volcanic units that overlie and, in some cases, pinch out (or abut) against the Eleana fm. (late Devonian-Mississippian age) and Chainman Shale (Mississippian age) siliciclastic units. The 2005 MT profiles crossed the topographic margin of the Rainier Mesa caldera (RMCT, pl. 1) and the outermost caldera of the Timber Mountain Caldera Complex (Slate and others, 1999). The structural margins of both the Ammonia Tanks and Rainier Mesa Caldera, and the resurgent dome of Timber Mountain, lie to the west of the survey area. The buried Silent Canyon caldera Complex also lies to the west of the survey area.

Yucca Flat and Mid Valley are elongate alluvial basins that formed as a consequence of regional crustal extension that was oriented generally east-west (Cole and others, 1997b). The overall geometry of the Yucca Flat basin was largely controlled by down-to-the-east displacements on the general northerly striking Carpetbag fault system that resulted in down-dropping and westward tilting of Miocene strata. Mid Valley is controlled by the Mine Mountain fault. Numerous smaller faults in the two basins also have northerly trends. These structural trends are displayed on plate 1 , a schematic image of the geology underlying the 2003 and 2005 areas of investigation. The geology depicted on plate 1 is a section of a much larger geologic map developed by Slate and many others (1999). The 26 MT data stations acquired in 2005 are indicated on Plate 1 by black circles labeled with a station number and MT data from 2003 that were used in the current analysis and interpretation are indicated by labeled blue triangles.

The geology presented on plate 1 is known to be quite complicated in areas where there are drill holes and rock outcrops for ground truth and is, possibly, more complicated in areas without ground truth. The complex Cenozoic and pre-Cenozoic stratigraphy of the Nevada Test Site have typically been combined into hydrogeologic groupings of aquifers and confining units (Winograd and others, 1975; Belcher and others, 2004, and Bechtel Nevada, 2006).
In the MT interpretations presented below, hydrogeologic groupings are used to label the inferred geologic units. Table 4 lists the abbreviated label names and the corresponding hydrologic grouping. The names are derived from Table 4-4 of the Bechtel Nevada report on the hydrostratigraphic framework of the Yucca Flat area (Bechtel Nevada, 2006).

The 2-D magnetotelluric interpretations of the electrical resistivities and structures under Rainier Mesa, Shoshone Mountain, Mid Valley, and Yucca Flat are presented in this section (figures 3-8). The interpreted resistivity models for Rainier Mesa/Shoshone Mountain (RM/SM) profiles generally fit the TM data better than the TE data (see Appendix A), although fits to the TE data were satisfactory for stations where 2-D structure was indicated. However, because of the widespread 3-D character of the survey area and as indicated by the modeling results, only the gross structure determined by the models is discussed. Vertical field data (the tipper strike) were also used to determine which measured component represented the TM mode and which represented the TE mode.

The interpretations presented reflect the diffusive nature of the MT technique and the non-uniqueness of the inverse problem. Properties of thin, conductive geologic units at great depths will not be well determined. A magnetotelluric detectability rule of thumb is to use a 10:1 ratio of depth to thickness. For example, at $10 \mathrm{~km}$ depth, a conductive unit 1 $\mathrm{km}$ thick may be detected. If the unit is less than $1 \mathrm{~km}$ thick at $10 \mathrm{~km}$ depth, its ability to be detected is decreased. Thus, the models in this report are possible representations of the subsurface geology. While the MT data support these representations, detailed resolution of structures at depth is limited.

Appendix A contains, for each profile, the final 2-D models (same as figures 3-8 but with the forward modeling mesh displayed and without the interpretations) and plots of the observed and calculated apparent resistivity and phase curves for each station. The models are organized by profile number (1-7) and subdivided by the model number shown in the upper right corner of the 2-D model figure. The " 1 " in

Table 4. Hydrostratigraphic and hydrogeologic groups and associated abbreviations

\begin{tabular}{lc}
\hline \multicolumn{1}{c}{ Hydrogeologic grouping } & Abbreviation \\
\hline Alluvial deposits and aquifer & A \\
Volcanic aquifers (vitric tuff units and welded tuff aquifer) & VTA \\
Welded tuff aquifer (partially to densely welded ash flow tuff) & WTA \\
Volcanic tuff confining unit (zeolitized bedded tuffs) & TCU \\
Cretaceous granitic confining units (Gold Meadows and Climax plutons) & MGCU \\
Upper carbonate aquifer (Tippipah Limestone) & UCA \\
Upper clastic confining unit (Eleana Fm, Chainman Shale) & UCCU \\
Lower carbonate aquifer (many Paleozoic carbonate formations) & LCA \\
Lower clastic confining unit (Cambrian-Precambrian Wood Canyon Fm., Precambrian Stirling Quartzite) & LCCU (Zws) \\
\hline
\end{tabular}


front of the station identifiers in figure 4 was required by the inversion software and should be ignored. Each model in the appendix is presented in the following order: First is the 2-D model without the interpretations shown in figures 4-9. Then the models are followed by figures showing the observed and calculated apparent resistivity sounding curves and, finally, by figures showing the observed and calculated MT impedance phase curves.

All the MT profile interpretations presented here have general similarities regarding the electrical resistivities of the different hydrogeologic units. The correlation of the geologic units and resistivities is based on well logs and the locations of rock outcroppings. Generally, the volcanic vitric tuffs are resistive (200-500 ohm-m) while the volcanic tuff confining units are conductive (20-50 ohm-m). The continental shelf Chainman Shale member of the upper clastic confining unit (UCCU) is more electrically conductive (around 10-50 ohm-m) than the upper part of the lower clastic confining unit (LCCU, consisting of shaly middle Cambrian through Devonian units) that has electrical resistivities around $50 \mathrm{ohm}-\mathrm{m}$. The western submarine fan Eleana Formation (carbonate turbidite and chertlithic clastic) member of the UCCU is more electrically resistive (100-500 ohm-m) than the Chainman Shale member The lower part of the LCCU (Precambrian and non-shaly Cambrian units) has resistivities around 200-10,000 ohm-m. The lower carbonate aquifer (LCA, consisting of several Paleozoic units) and the upper carbonate aquifer (UCA, consisting of the Tippipah Limestone of Pennsylvanian and lower Permian age) are electrically resistive (around 200-2000 ohm-m). The volcanic aquifers and confining units (VTA and WTA) are moderately electrically conductive (20-50 ohm-m) while the alluvial deposits and aquifers (A) are moderately resistive (around 50-100 ohm-m). Marble and granite (MGCU consisting of Cretaceous quartz monzonite or granodiorite) units along profile RM6 near station RM25 (Gold Meadows stock) and at the northern end of the Yucca Flat basin (the Climax stock) vary from quite conductive to resistive (around 10-500 ohm-m).

\section{Profile RM1 (Stations RM5-8, YF21-28)}

Profile RM1 begins just east of Buckboard Mesa in the west, progresses east as it curves around Syncline Ridge, and then crosses the middle of the Yucca Flat basin (see fig. 2). Profile RM1 consists of projections of RM/SM MT stations 5-8 and Yucca Flat (YF) stations 21-28. The 2-D inversion and forward modeling refinement interpretation for Profile RM1 is presented in figure 3. Resistivity model 28, lithologically, shows electrically conductive volcanic rocks (10-50 ohm-m) of the WTA and TCU overlying, under RM/SM MT stations 5, 6 and 7, the more resistive (200-5,000 ohm-m) LCA. Under stations YF21-24 resistive carbonate rocks of the UCA (Tippipah Limestone) are interpreted to overlie the, generally, more conductive (10-50 ohm-m) UCCU in possibly a synclinal relationship (consistent with surface geological observations on plate 1). The UCCU, in turn, overlies the more resistive $(100-200 \mathrm{ohm}-\mathrm{m})$ LCA unit that extends below $10 \mathrm{~km}$ depth. Under stations YF27-28 moderately resistive (predominantly $100 \mathrm{ohm}-\mathrm{m}$ ) alluvial deposits (up to $400 \mathrm{~m}$ thick) are interpreted to overlie moderately conductive (predominantly $50 \mathrm{ohm}-\mathrm{m}$ ) volcanic rocks of the TCU (approximately $800 \mathrm{~m}$ thick) that, in turn, overlie resistive (200-2,000 ohm-m) carbonates of the LCA.

Structurally, there appear to be large faults crossing this profile (Cole and others, 1997a, 1997b, and Slate and others, 1999). Coming near the surface beneath station YF25 and extending to depth beneath stations YF26-28 it is inferred that the CP Thrust is controlling the distribution of the LCA hydrogeologic units. At depths to approximately $2 \mathrm{~km}$, it appears that the Yucca Fault is cutting off the volcanic and alluvial units between stations YF26-28.

The polar plots in Williams and others (2006) for stations RM5-8 and in Williams and others (2005a) for stations YF21-28 indicate both 2-D and three-dimensional (3-D) geologic structural character along Profile RM1 (fig. A3 and A4). The tipper strike indicates that the electrical resistivity structure is sub-parallel to the geologic structure near stations RM5-8, YF22-24, and YF27-28. The 3-D structure begins to affect station YF21 at about $2 \mathrm{~km}$ away (in distance or depth or both). At stations YF25-26 the structure is 3-D beyond or below $10 \mathrm{~km}$ depth. By definition, the TE mode is perpendicular to the profile direction and parallel to the electrical resistivity structure. For cases, such as at stations RM5-8, YF22-24, and YF27-28, the assumption of a TE mode was invalid and so only the TM mode was fit (fig. A3).

\section{Profile RM2b (Stations RM13-20, YF44, 46)}

Profile RM2b (fig. 2) begins, in the west, just east of Buckboard Mesa (RM13-16), skirts around and crosses over part of Rainier Mesa (RM17-19), progresses over the Eleana Range (RM20), crosses the northern end of the Yucca Flat basin (YF44), and ends near Quartzite Ridge in the hills just to the north of Yucca Flat (YF46). The 2-D inversion and forward modeling refinement interpretation for Profile RM2b (Model 204 ) is presented in figure 4 . The modeling program required adding a " 1 " to the station names. Station RM16 was not used in the inversion analysis. It was located at the junction of Pahute Mesa Road and Rainier Mesa Road and subsequently had too much cultural noise due to local power lines and passing trucks and cars. The inversion and forward modeling analysis indicates that stations RM13-18 are located on a thin section of the volcanic unit VTA that overlies a thicker section (up to $1 \mathrm{~km}$ thick) of the TCU and/or WTA. It is possible that either the UCCU or the upper shaly member of the LCCU underlie the TCU/WTA beneath stations RM13-15. Determination of which unit is underlying the TCU is discussed below. Stations RM17-18 are located on thinner sections (up to $500 \mathrm{~m}$ thick) of the TCU, which may also overlie a 500-m thick unit of UCCU. A resistive LCA unit, located between stations RM18 and RM19, overlies what is interpreted to be UCCU (possibly upper LCCU) material. This resistive member of the LCA was emplaced by an older thrust fault. Investigatory borehole 
2-D Model

rm1tmbf28
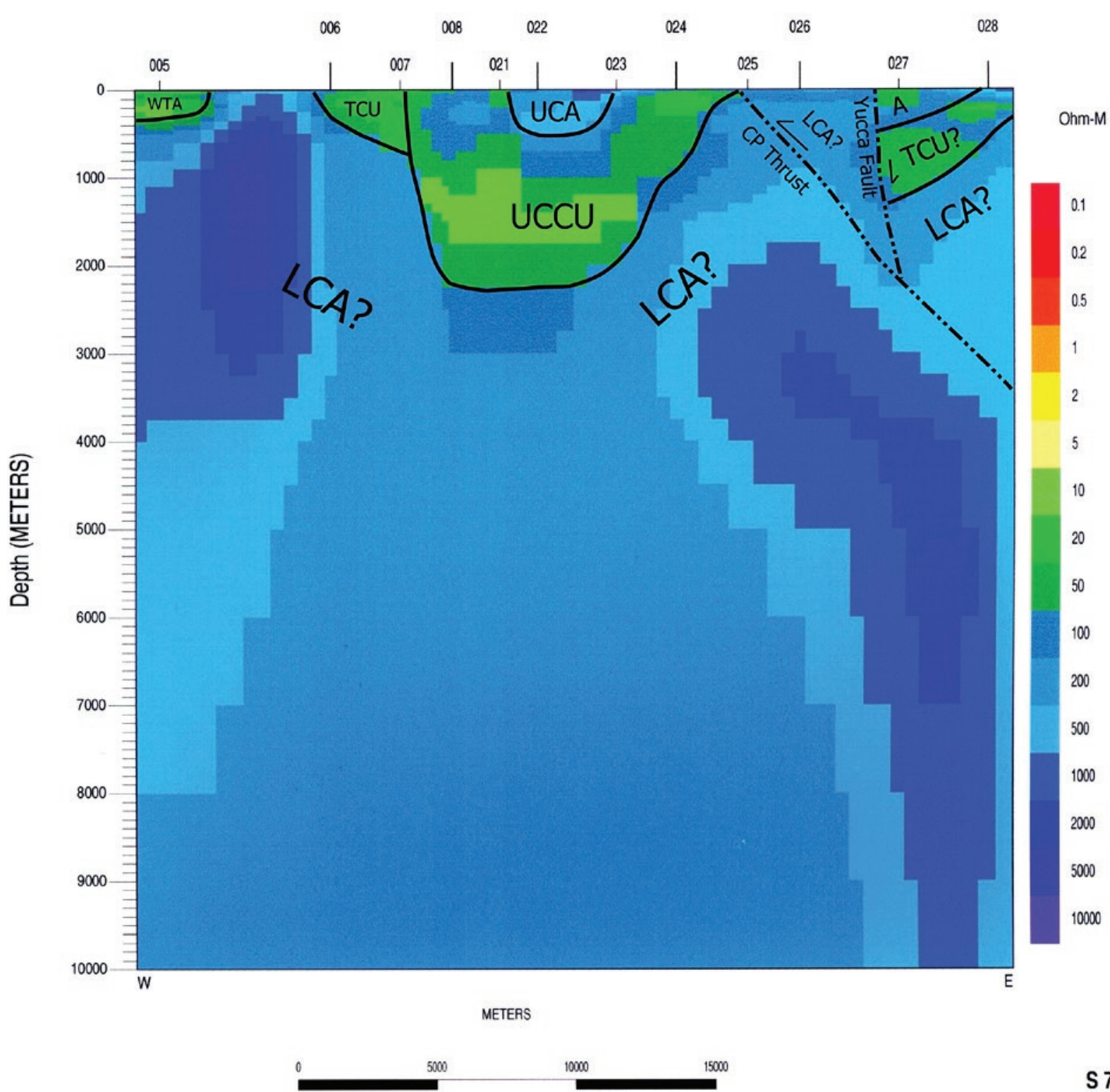

S $74 \mathrm{E}$

Figure 3. 2-D modeling results for Profile RM1. Model 28. Refer to Table 4 for key to hydrogeologic unit abbreviations.

ER12-1 (pl. 1) is projected onto the profile at station RM19. While the modeled section is generally consistent with the logged borehole lithology, the small tick mark on the well at a depth of $1 \mathrm{~km}$ indicates the depth at which dolomite material of the LCA was encountered in the well, about $250 \mathrm{~m}$ shallower than what is indicated by the resistivity model. Station RM20 is interpreted to be located on a thick section of UCCU. Station YF44 on the northern end of Yucca Flat basin is interpreted to be on a thick section of UCCU, which may be an upturned arm of a syncline. Station YF46 is interpreted to be located on an approximately $4 \mathrm{~km}$ thick section of the UCCU in which the upper $2 \mathrm{~km}$ is interpreted to be Eleana Formation material and the lower $2 \mathrm{~km}$ thick section is interpreted to be composed of Chainman Shale material. The LCA is interpreted to underlie UCCU beneath stations RM15-20, YF44, and YF46.

Structurally, several faults affect the rock units along this profile. The Belted Range Thrust fault is interpreted to underlie stations RM14-17 and cut off the LCCU/UCCU units therein. The Belted Range Thrust is mostly defined by intercepts of Precambrian Wood Canyon Fm. in deep holes beneath Rainier Mesa and in limited outcrops in Gold Meadows. It is a thrust fault with the west side up, bringing Precambrian units over the LCA. Additional thrust faults, with the west side up, underlie stations RM17-20. The conductive unit below the TCU/WTA 
Discussion

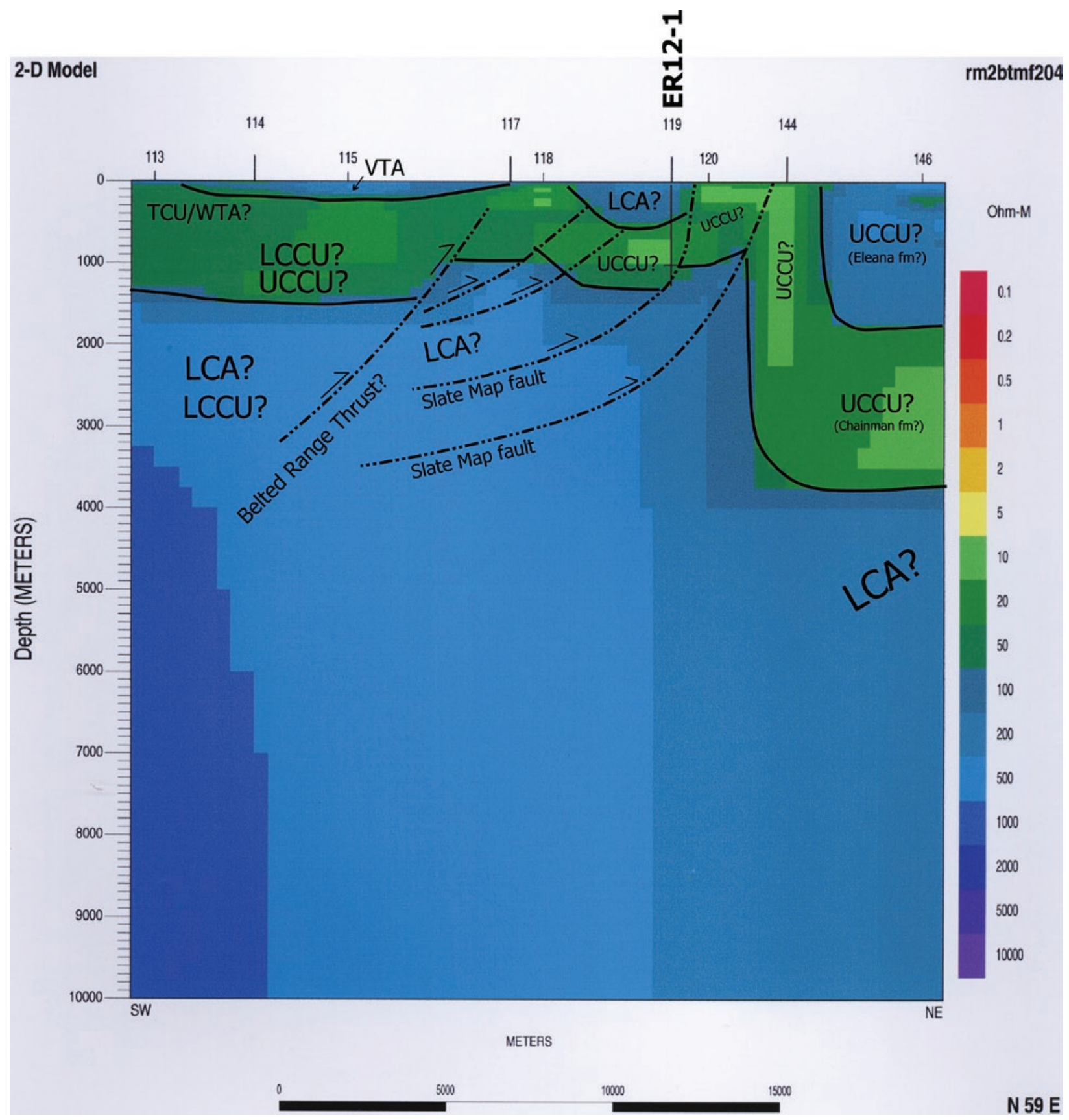

Figure 4. 2-D modeling results for Profile RM2b. Model 204. Refer to Table 4 for key to geologic unit abbreviations. ER12-1 is an investigatory borehole.

under stations RM13-15 is the upper shaly member of the LCCU. Note that it is possible that what is labeled as LCA underlying stations RM13-15 may actually be, in part, lowermember LCCU material.

Two other faults on pl. 1 are located just to the west and east of station RM20 on either edge of the Eleana Range. The fault west of RM20 may be another thrust fault within the Eleana fm. Finally, stations YF44 and YF46 are interpreted to be located on a synclinal structure.
A comparison of model 204 and polar plots in Williams and others (2006) and Williams and others (2005e) results in the dimensionality indicated on figures A6 and A7. The geology under stations RM13, RM17-18, and YF44 is interpreted from the tipper strike to be sub-parallel (2-D) to the geologic strike direction while the geology under stations RM14 and RM19-20 are interpreted to be 3$\mathrm{D}$ at depths below $14 \mathrm{~km}$. The geology under station YF46 is $3-\mathrm{D}$ in the near surface. 


\section{Profile RM2d (Stations RM13-20, YF37-42)}

Profile RM2d (fig. 2) begins, like Profile RM2b, just east of Buckboard Mesa (RM13-16), skirts around and crosses over part of Rainier Mesa (RM17-19), progresses over the Eleana Range (RM20), and then crosses the northern end of the Yucca Flat basin (YF37-42). Model 43, the 2-D inversion and forward modeling refinement interpretation for Profile RM2d, is presented in figure 5. As with Profile RM2b discussed above, Stations RM13-18 are located on a thin to moderately thick section of the volcanic unit VTA that overlies a thicker section (up to $1 \mathrm{~km}$ thick) of the TCU. It is possible that UCCU or upper LCCU underlie the TCU beneath stations RM13-15. Stations RM17-18 are located on a section (up to $500 \mathrm{~m}$ thick) of the TCU that may also overlie a 500-m thick unit of UCCU. A resistive LCA unit, located between stations RM18 and RM19, overlies what is interpreted to be UCCU (possibly upper LCCU) material. This resistive rock is a member of the LCA that was emplaced by an older thrust fault. The thickness of the LCA is consistent with that observed in investigatory borehole ER12-1 (pl. 1). Station RM20 is interpreted to be located on a thin section of TCU overlying UCCU material. Station YF37 is interpreted as being located on approximately $400-500 \mathrm{~m}$ of TCU that is overlying a $1 \mathrm{~km}$ thick section of UCCU based on nearby drill holes U2ca\#1, U2ce, and UE2ce, which are east of station 37. Station YF38 is situated on a $1.5 \mathrm{~km}$ thick section of LCA that has been thrust onto a $1 \mathrm{~km}$ thick section of UCCU. Stations YF39-41 are on alluvium deposits that are overlying volcanic TCU materials. The volcanic units can be represented by a $50-\mathrm{ohm}-\mathrm{m}$ resistivity distribution whose boundaries approximate those derived from nearby shallow wells U2r1, U2z-1, U9d, U9co, U9aw, U9bi-1, U9bi-2, UE9cp, U9cm, and UE9cn (see pl. 1 of Cole and others (1997) for well locations). As with Profile RM2b, units of the LCA are possibly underlying the UCCU and TCU units along this profile.

Structurally, several faults affect the rock units along this profile. The Belted Range Thrust fault is interpreted to underlie stations RM14-17 and cut off the LCCU/UCCU units therein. As discussed previously, the Belted Range Thrust is mostly defined by intercepts of Precambrian Wood Canyon Fm. in deep holes beneath Rainier Mesa and in limited outcrops in Gold Meadows. It is a thrust fault with the west side up, bringing Precambrian units over the LCA. The conductive unit below the TCU is the upper LCCU. Note that it is possible that what is labeled as LCA underlying stations RM13-15 may actually be, in part, lower LCCU material. Two other faults on pl. 1 are located just to the west and east of station RM20 on either edge of the Eleana Range and within the Eleana fm.

Structurally, the CP Thrust fault appears to approach the surface just east of station YF37. Note that the UCCU material below stations YF37 and YF38 is interpreted as being tilted due to motion upwards on the west on the unnamed fault in pl. 1. The geologic image on pl. 1 also suggests that a fault may be present just east of station YF38. The Carpetbag fault, which, in pl. 1, is part of a complicated fault zone, is suggested to be located just west of station YF39. The modeling results also suggest a fault just west of station YF40. The geologic image in pl. 1 suggests that this fault is likely the northerly-trending Yucca Fault.

A comparison of model 43 and the polar plots in Williams and others (2006) and in Williams and others (2005b) indicates that the geology along the profile is generally 2-D in nature with some more complicated 3-D zones near Rainier Mesa and near complex faulting in the Yucca Flat basin. The tipper strike inferences are drawn on the measured and calculated apparent resistivities and impedance phases in figures A9 and A10. The tipper strike indicates that the geologic structure under stations RM13, 15, 17 and 18 is sub-parallel to the profile and/or geologic strike. However, the geologic structure under station RM14 east of Buckboard Mesa and under stations RM19 and RM20, next to Rainier Mesa and on the Eleana Range, respectively, are more 3-D in nature. The Tipper strike indicates that the resistivity structure is sub-parallel to the profile beyond or below $17 \mathrm{~km}$ at station YF37 based on skin depth calculations. Elsewhere under the stations along the profile the geology is approximately 2-D except where it is indicated to be 3-D in nature under station YF39 in the shallow alluvium and beyond or below $14 \mathrm{~km}$ depth or both at stations YF41 and YF42.

\section{Profile RM4 (Stations RM1-4, YF9-14)}

Profile RM4 begins west of Shoshone Mountain (station RM1) and progresses eastwards across Shoshone Mountain (RM2-4), across northern Mid-Valley (YF9-11), over Mine Mountain (YF12-13), and down into Yucca Basin at station YF14. Model 28 (fig. 6) is the 2-D inversion and forward modeling refinement interpretation of the geology and structure along Profile RM4. Stations RM1-3 are located on an inferred $1-1.5 \mathrm{~km}$ thick section of UCCU material that is overlying units of the LCA. Electrically resistive volcanic welded rhyolite tuff material of the VTA and welded tuff aquifer (WTA) units (Timber Mountain group and Paintbrush Group (Slate and others, 1999), about 400-500 m thick, is situated between stations RM3 and RM4. While boundaries are suspected between the resistive VTA and the underlying resistive material of possibly the Eleana Formation and the LCA, they could not be resolved. Station RM4 is on VTA material that is underlain by about $1.5 \mathrm{~km}$ of conductive UCCU (20-50 ohm-m). In the northern Mid Valley basin stations YF9-10 are situated on some thin alluvium material that is overlying resistive LCA $(200-500 \mathrm{ohm}-\mathrm{m})$ that has been thrust onto younger electrically conductive UCCU (20-50 ohm-m). This conductive material could be the Chainman Shale.

Between stations YF11 and YF12 UCCU material (possibly the Eleana $\mathrm{fm}$.), of about $400 \mathrm{~m}$ thickness, is overlying LCA units. Rock units of the LCA are also the underlying material beneath stations YF13 and YF14.

The geology traversed by Profile RM4 is structurally complex. Faulting and folding are dominant throughout the section. Low angle thrust faults, west side up, are located between stations RM3 and RM4. Another low angle thrust 


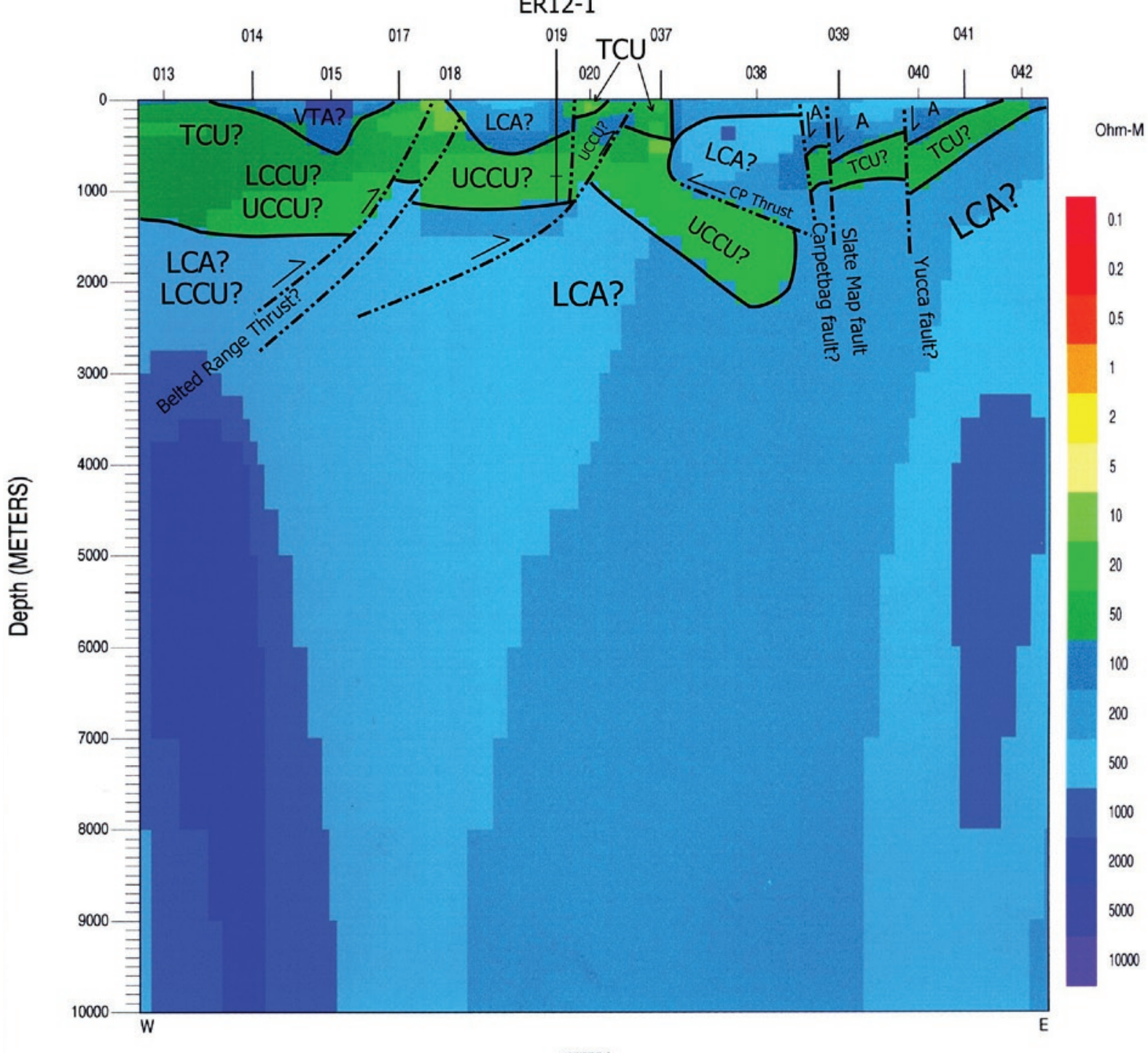

METERS

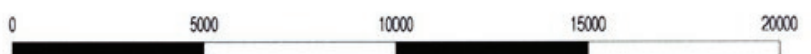

S $89 \mathrm{E}$

Figure 5. 2-D modeling results for Profile RM2d. Model 43. Refer to Table 4 for key to geologic unit abbreviations. ER12-1 is an investigatory borehole projected onto the profile.

fault that is located, at depth, between stations RM4 and YF9. While the geologic structure around station YF12, located on the east side of Mine Mountain, is quite complex, only a thrust fault that is possibly the $\mathrm{CP}$ thrust is depicted in the figure.

Examination of the polar plots in Williams and others (2006) for stations RM1-4 and for stations YF9-14 in Williams and others (2005d) indicates that the geology at most stations along Profile RM4 is generally 3-D in character. The interpreted dimensionality is indicated on figures A12 (measured and calculated apparent resistivity) and A13 (measured and calculated impedance phase). Only station RM2 exhibits a 2-d structural character. Stations RM1, 3 and 4 exhibit 3-D character about 1-2 $\mathrm{km}$ or more away in depth or distance or both. Station YF9 appears to be 3-D from the near-surface to at least $10 \mathrm{~km}$ away in depth or distance or both. Stations YF10-14 exhibit 3-D character at great distances (over $20 \mathrm{~km}$ in distance or depth or both).

\section{Profile RM6 (Stations RM21-26, YF45-49)}

Profile RM6 starts on Pahute Mesa in the west (station RM21), crosses Rainier Mesa (RM22-26), and continues across Quartzite Ridge (YF45-46) and the Climax Stock (YF47-49). Model 57 (fig. 7) is the 2-D inversion and forward 
2-D Model

rm4tmbf28
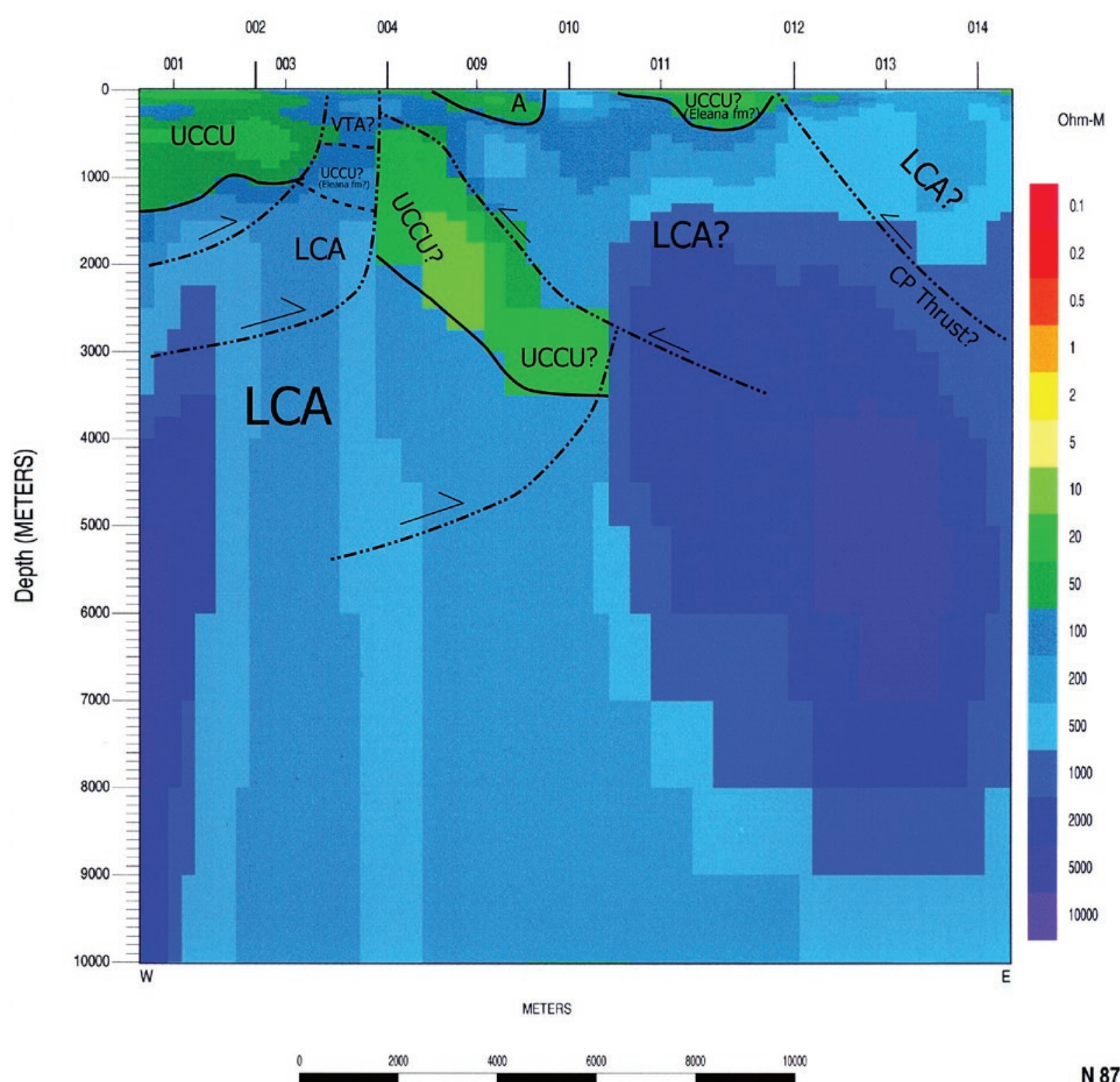

Figure 6. 2-D modeling results for Profile RM4. Model 28. Refer to Table 4 for key to geologic unit abbreviations.

modeling refinement interpretation of Profile RM6. While station RM21 is located on a thin $(150 \mathrm{~m})$ layer of resistive VTA (200-500 ohm-m) that is overlying a $250 \mathrm{~m}$ thick zone of conductive (20-50 ohm-m) TCU material, station RM22 is located on a down-dropped block of similar, but thicker material (VTA approximately $600 \mathrm{~m}$ thick, TCU approximately 400 $\mathrm{m}$ thick). The geology under station RM23 is similar in character to station RM21 - a thin 300 m zone of VTA overlying a $150 \mathrm{~m}$ thick zone of TCU material. The underlying material beneath the volcanics under stations RM21-23 is resistive and is interpreted to consist of lower member Cambrian-Precambrian rock of the LCCU. Underlying this LCCU material is electrically resistive LCA material. Under stations RM24-25, these rocks abut against conductive (5-50 ohm-m) Mesozoic granitic material (MGCU) that has probably undergone some mineral alteration. Above the deeper granitic material under station RM25 is a wedge-like zone of resistive (1000 ohm-m) LCCU overlying resistive LCA material. Nearer to the surface is a $300-400 \mathrm{~m}$ thick section of volcanic VTA material. TCU material, 200 to $400 \mathrm{~m}$ thick, is interpreted to be present beneath stations RM26 on Rainier Mesa and station YF45. Station YF46, which is located on Quartzite Ridge, is on a very thin layer of volcanics overlying resistive (250-500 ohm-m) UCCU material (Eleana fm.) that is $2-3 \mathrm{~km}$ thick and which is in turn overlying conductive (50 ohm-m) UCCU material which is likely Chainman Shale material. Units of 
the LCA underlie station YF47 while station YF 48 is located near the boundary of LCA material and the granitic intrusive Climax Stock (labeled MGCU in fig. 7). Station YF49 is on a shallow section of alluvial material that overlies a very thin $(150 \mathrm{~m})$ section of volcanics, which is overlying a thick section of LCCU material.

The geologic structures encountered along Profile RM6 are quite complex due to folding, faulting, and intrusion by the Mesozoic granitic masses. Several small faults are controlling the distribution of volcanic material under stations RM21-23. The Belted Range thrust fault affected the placement of units just east of the Gold Meadows granitic stock and another thrust fault has juxtaposed what is interpreted to be LCA units on UCCU material between stations RM26 and YF45. The Tippinip fault (Cole and others, 1997), a strike-slip fault, is exposed near station YF47. A fault is also indicated just west of the Climax Stock near station YF48. On the east side of the Climax Stock, near station YF49, a fault that correlates with the Area 13 fault or the Yucca fault is indicated.

An examination of the polar plots in Williams and others (2006) for stations RM21-26 and for stations YF45-49 in Williams and others (2005e) indicates that the geology along this profile is generally 3-D in nature. The interpretations are presented on figures A15 and A16, the measured and calculated apparent resistivity and impedance phase plots. Station RM21 is 3-D in nature within about $1 \mathrm{~km}$ in distance away or

\section{2-D Model}

rm6btmf57

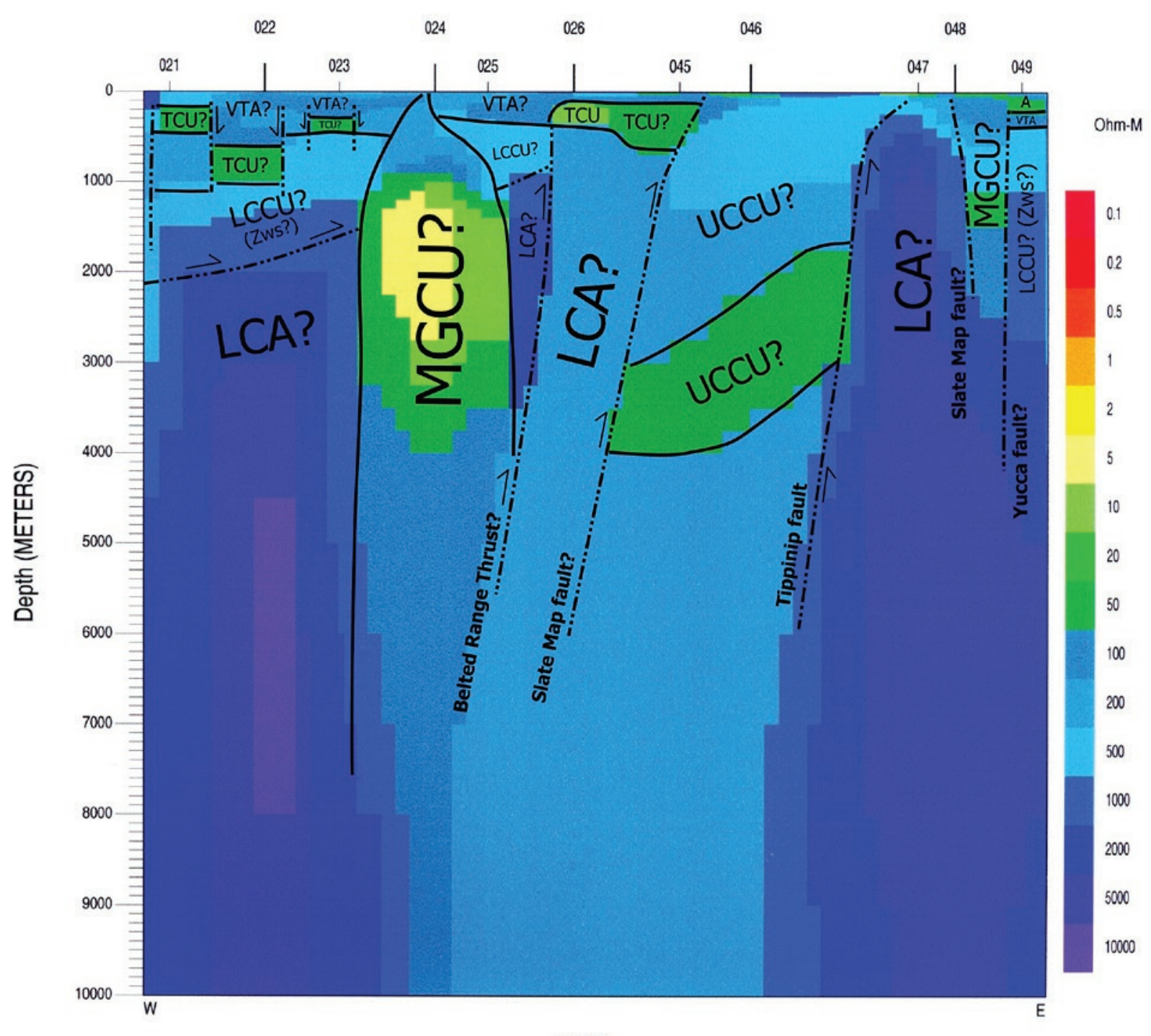

METERS

Figure 7. 2-D modeling results for Profile RM6. Model 57. Refer to Table 4 for key to geologic unit abbreviations. 
depth below while the geology at station RM22 is sub-parallel or 2-D in character at depth. Stations RM23 and RM24 are

$3-\mathrm{D}$ at a distance or depth of 1-2 km. Station RM25 has a

$2-\mathrm{D}$ character in the near surface $(<500 \mathrm{~m})$. The structural character could not be determined from the polar plots at station RM26. At station YF45 the structural character is 3-D at a depth of about $20 \mathrm{~km}$ or at a distance away of about $20 \mathrm{~km}$ or both. Station YF46 is 3-D from the near-surface to about $1 \mathrm{~km}$ in depth or distance or both. The MT data near Station YF47 indicates that the geology is 3-D within about $500 \mathrm{~m}$ in depth or distance or both while station YF49 is 3-D at several kilometers distance or depth. The structure near station YF48, on the edge of the Climax Stock, is 2-D in character and subparallel to the profile beginning near the surface and continuing to great depths $(20 \mathrm{~km})$.

\section{Profile RM7 (Stations RM9-12, YF29-36)}

Profile RM7 (fig. 2) begins in the west just east of Buckboard Mesa (RM9-11), crosses over the Eleana Range (RM12, YF29), and continues across the Yucca Flat basin (YF30-36). The 2-D inversion and forward modeling refinement interpretation for Profile RM7 is presented in Model 44 (fig. 8). Under stations RM9-11 volcanic units of the conductive (20-50

\section{2-D Model}

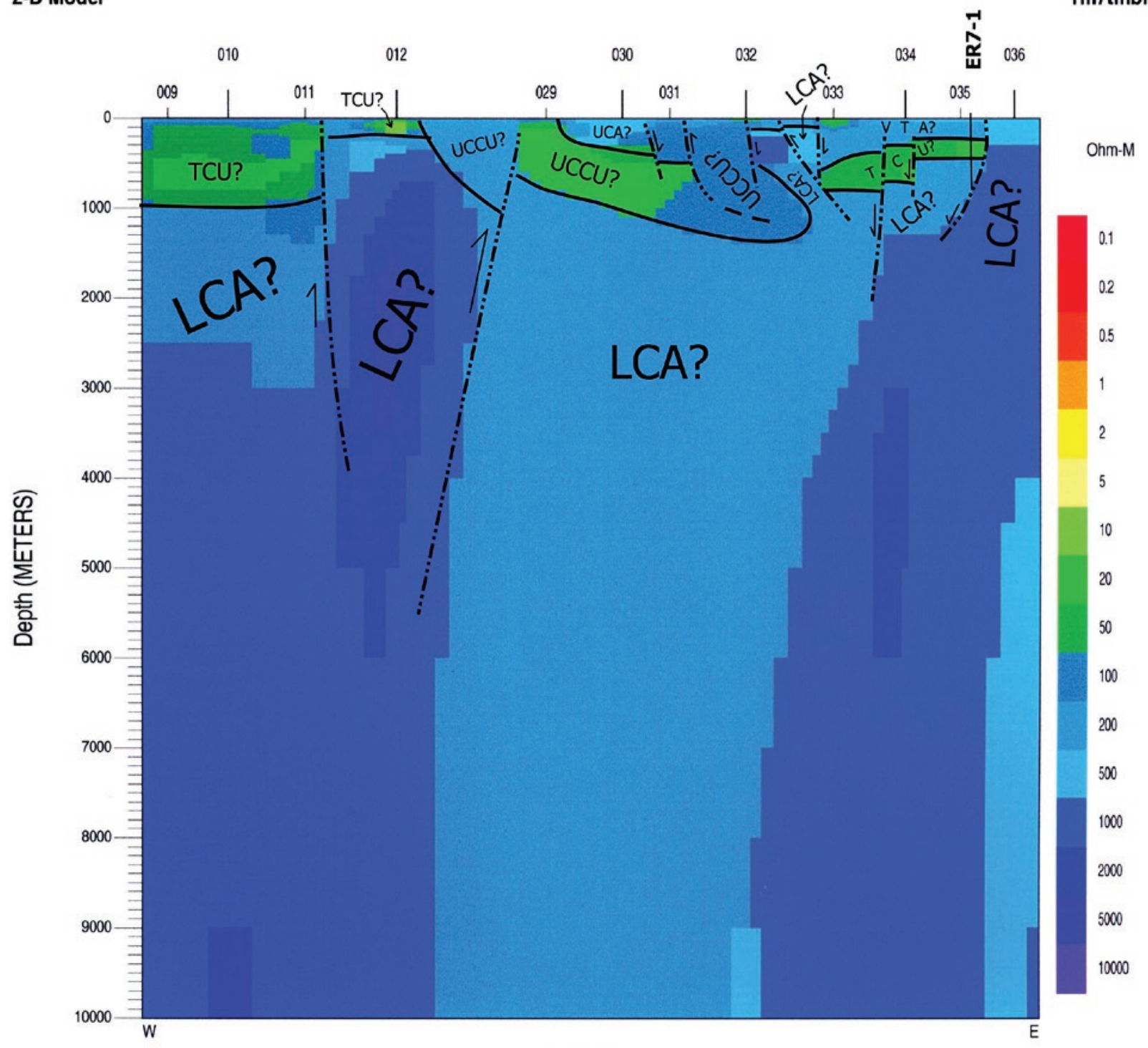

METERS

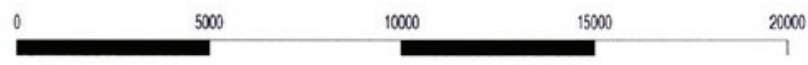

Figure 8. 2-D modeling results for Profile RM7. Model 44. Refer to Table 4 for key to geologic unit abbreviations. 
ohm-m) TCU, about $1 \mathrm{~km}$ in thickness, overlie what is interpreted to be units of the resistive (250-1000 ohm-m) LCA. The interpreted topographic margin (Slate and others, 1999) of the Rainier Mesa caldera is located just east of station RM11. Beneath a thin layer of conductive TCU material (approximately 150 m thick), units of the LCA underlie station RM12. The Eleana Range is indicated by the resistive (200-500 ohm-m) UCCU material between stations RM12 and YF29. The interpreted section in figure 8 between stations RM9-12 is similar to the gravity model and geologic interpretation presented in figures 3 and 4 of Phelps and others (1999). Probably Chainman Shale (about $800 \mathrm{~m}$ thick) underlies station YF29 while under station YF30 are units of the UCA (about $300 \mathrm{~m}$ thick), which is overlying UCCU Chainman Shale (about 800 $\mathrm{m}$ thick). It is interpreted from nearby borehole data that an overturned fold of UCCU that has later been faulted is present between stations YF30 and YF33. Under station YF32, in particular, an overturned fold of UCCU Eleana fm and LCA material has been interpreted (Jim Cole, personal comm.). The CP Thrust may also have positioned the LCA over the UCCU between stations YF32-33. In the Yucca Flat basin, resistive (200-500 ohm-m) VTA material (about $300 \mathrm{~m}$ thick) is overlying more conductive (20-50 ohm-m) TCU material (about 200-400 m thick) between stations YF33 and YF36. These volcanic units are underlain by members of the LCA group.

It is interpreted that a thrust fault is located in the Eleana Range west of station YF29. Thrust and normal faults are present between stations YF29 to YF31 as is folding that may be a northern extension of Syncline Ridge. The eastern end of the profile is dominated by normal faults. The eastward-dipping Carpetbag and a component of the CP Thrust faults are interpreted to cross between stations YF32 and YF33. Alluvial and volcanic units appear to be affected by the eastward-dipping Yucca Fault that is interpreted to cross between stations YF33 and YF34 and unnamed westward-dipping faults that are located between stations YF35 and YF36.

A comparison of model 44 with polar plots in Williams and others (2006) for stations RM9-12 and for stations YF2936 in Williams and others (2005f), presented in figures A18 and A19, indicates that the geology at stations RM9, YF29-36 is 3-D at about 10-20 km in depth or in distance away or both. The geology beneath stations RM10 and RM12 is 2-D at about $5 \mathrm{~km}$ in depth or in distance away or both while under station RM11 the geology is 2-D from about $150 \mathrm{~m}$ depth or distance or both and on out to greater depths.

\section{Summary}

The MT data stations collected by the U.S. Geological Survey in 2003 and in 2005 have helped to characterize the deep resistivity structure in the pre-Tertiary geology beneath Rainier Mesa, northern Mid Valley, Shoshone Mountain, the Eleana Range, and the Yucca Flat areas of the Nevada Test Site. The character, thickness, and lateral extent of the Chainman Shale and Eleana Formation that comprise the Upper
Clastic Confining Unit (UCCU) are generally characterized in the upper 5-km. The interpretation is not well determined where conductive TCU overlies conductive Chainman Shale, where resistive Eleana Formation overlies resistive LCA units, or where resistive VTA rock overlies units of the Eleana Formation. The nature of the volcanic units in the west has been refined as are large and small fault structures such as the CP Thrust Fault, the Carpetbag Fault, and the Yucca Fault that cross Yucca Flat. The subsurface electrical resistivity distribution and inferred geologic structures determined by this investigation should help constrain the hydrostratigraphic framework model that is under development for the Rainier Mesa/Shoshone Mountain Corrective Action Unit and areas to the west and in understanding the effects on ground-water flow in the area.

\section{References Cited}

Asch, T.H., Rodriguez, B.D., Sampson, J.A., Wallin, E.L., and Williams, J.M., 2006, Deep Resistivity Structure of Yucca Flat, Nevada Test Site, Nevada: U. S. Geological Survey Open-File Report OFR 06-1261, U. S. Geological Survey, Denver, Colorado, 86pp.

Bechtel Nevada, 2006, A hydrostratigraphic model and alternatives for the groundwater flow and contaminant transport model of Corrective Action Unit 97: Yucca Flat-Climax Mine, Lincoln and Nye counties, Nevada: DOE/NV/117181119. Las Vegas, NV.

Belcher, W.R., editor, 2004, Death Valley regional groundwater flow system, Nevada and California-Hydrogeologic framework and transient ground-water flow model: U.S. Geological Survey Scientific Investigations Report 20045205, 408 p.

Bendat, J.S., and Piersol, A.G., 1971, Random data-analysis and measurement procedures: New York, Wiley Interscience, $407 \mathrm{p}$.

Cole, J. C., Harris, A. G., and Wahl, R. R., 1997a, Subcrop geologic map of pre-Tertiary rocks in the Yucca Flat and northern Frenchman Flat areas, Nevada Test Site, southern Nevada: U.S. Geological Survey Open-File Report 97-678, scale 1:48,000, $24 \mathrm{p}$.

Cole, J.C. and Cashman, P.H., 1997b, Geologic map of the Mine Mountain area, Nevada Test Site, southern Nevada: U.S. Geological Survey Open-File Report 1997-697, 13 p.

Dobrin, M.D., and Savit, C.H., 1988, Introduction to geophysical prospecting (4th ed.): New York, McGraw-Hill, 867 p.

Eberhart-Phillips, Donna, Stanley, W.D., Rodriguez, B.D., and Lutter, W.J., 1995, Surface seismic and electrical methods to detect fluids related to faulting: Journal of Geophysical Research, v. 100, no. B7, p. 12919-12936. 
Egbert, G.D., 1997, Robust multiple station magnetotelluric data processing: Geophysics Journal International, 130, p. 475-496.

EMI, 1996, MT-1 magnetotelluric system operation manual, version 3.2: Richmond, Calif., ElectroMagnetic Instruments, Inc., 220 p.

EMI, 2002, MT24/LF System Operation and Maintenance Manual, version 1.0: Richmond, Calif., ElectroMagnetic Instruments, Inc., $72 \mathrm{p}$.

Gamble, T.D., Goubau, W.M., and Clarke, J., 1979, Error analysis for remote reference magnetotellurics: Geophysics, V. 44, no. 5, p. 959-968.

Keller, G.V., 1987, Rock and mineral properties, in Nabighian, M.N., ed., Electromagnetic methods in applied geophysics theory: Tulsa, Okla., Society of Exploration Geophysicists, v. 1, p. $13-51$.

Keller, G.V., 1989, Electrical properties, in Carmichael, R.S., ed., Practical handbook of physical properties of rocks and minerals: Boca Raton, Fla., CRC Press, p. 359-427.

Mackie, Randall, Rieven, Shirley, and Rodi, William, 1997, Users manual and software documentation for two-dimensional inversion of magnetotelluric data: GEOTOOLS User's Guide RLM2DI Supplement, 10 p.

Nelson, P.H., and Anderson, L.A., 1992, Physical properties of ash flow tuff from Yucca Mountain, Nevada: Journal of Geophysical Research, v. 97, no. B5, p. 823-6841.

Palacky, G.J., 1987, Resistivity characteristics of geologic targets, in Nabighian, M.N., ed., Electromagnetic methods in applied geophysics theory: Tulsa, Okla., Society of Exploration Geophysicists, v. 1, p. 53-129.

Phelps, G.A., McKee, E.H., Sweetkind, D.S, and Langenheim, V.E., 1999, Preliminary model of the pre-Tertiary basement rocks beneath Yucca Flat, Nevada Test Site, Nevada, based on analysis of gravity and magnetic data: U.S. Geological Survey Open-File Report 2000-134, 11 p.

Reddy, I.K., Rankin, David, and Phillips, R.J., 1977, Three-dimensional modelling in magnetotelluric and magnetic variational sounding: Geophysics Journal of the Royal Astronomical Society, v. 51, p. 313-325.

Rodi, William, and Mackie, R.L., 2001, Nonlinear conjugate gradients algorithm for 2-D magnetotelluric inversion: Geophysics, v. 66, no. 1, p 174-187.

Slate, J.L., Berry, M.E., Rowley, P.D., Fridrich, C.J., Morgan, K.S., Workman, J.B., Young, O.D., Dixon, G.L., Williams, V.S., McKee, E.H., Ponce, D.A., Hildenbrand, T.G., Swadley, W.C., Lundstrom, S.C., Ekren, E.B., Warren, R.G., Cole, J.C., Fleck, R.J., Lanphere, M.A., Sawyer, D.A., Minor, S.A., Grunwald, D.J., Laczniak, R.J., Menges, C.M.,
Yount, J.C., and Jayko, A.S., 199912, Digital Geologic Map of the Nevada Test Site and Vicinity, Nye, Lincoln, and Clark Counties, Nevada, and Inyo County, California: U. S. Geological Survey Open-File Report OFR 99-554-A, U. S. Geological Survey, Denver, Colorado.

Sternberg, B.K., Washburne, J.C., and Pellerin, Louise, 1988, Correction for the static shift in magnetotellurics using transient electromagnetic soundings: Geophysics, v. 53, p.1459-1468.

DOE UGTA Fact Sheet, 2003, Underground Test Area Fact Sheet: DOE/NV-915, August 2003, 2pp.

Vozoff, Keeva, 1972, The magnetotelluric method in the exploration of sedimentary basins: Geophysics, v. 37, p.980-141.

Vozoff, Keeva, 1991, The magnetotelluric method, in Nabighian, M.N., Electromagnetic methods in applied geophysics: Tulsa, Okla., Society of Exploration Geophysicists, v. 2, pt. B, p.641-711.

Wannamaker, P. E., 1983, Resistivity structure of the northern Basin and Range: Geothermal Resources Council, Special Report No. 13, p. 345 - 361.

Wannamaker, P. E., Hohmann, G. W., and Ward, S. H., 1984, Magnetotelluric responses of three-dimensional bodies in layered earths: Geophysics, vol. 49, no. 9, p. 1517 - 1533.

Wannamaker, P. E., Stodt, J. A., and Rijo, L., 1987, PW2D: finite element program for solution of magnetotelluric responses of two-dimensional earth resistivity structure, (User documentation): Earth Science Laboratory, University of Utah Research Institute, Salt Lake City, Utah, 40p.

Williams, J. M., Rodriguez, B. D., and Asch, T. H., 2005a, Magnetotelluric data, central Yucca Flat, Nevada Test Site, Nevada: U.S. Geological Survey Open-File Report 2005$1238,174 \mathrm{p}$.

Williams, J.M., Rodriguez, B.D., and Asch, T.H., 2005b, Magnetotelluric data, northern Yucca Flat, Nevada Test Site, Nevada: U.S. Geological Survey Open-File Report 2005$1239,120 \mathrm{p}$.

Williams, J.M., Rodriguez, B.D., and Asch, T.H., 2005d, Magnetotelluric data, southern Yucca Flat, Nevada Test Site, Nevada: U.S. Geological Survey Open-File Report 2005$1241,210 \mathrm{p}$.

Williams, J.M., Rodriguez, B.D., and Asch, T.H., 2005e, Magnetotelluric data across Quartzite Ridge, Nevada Test Site, Nevada: U.S. Geological Survey Open-File Report 2005-1242, 174 p.

Williams, J.M., Rodriguez, B.D., and Asch, T.H., 2005f, Magnetotelluric data, north central Yucca Flat, Nevada Test Site, Nevada: U.S. Geological Survey Open-File Report 2005-1243, $156 \mathrm{p}$. 
Williams, J.M., Sampson, J.A., Rodriguez, B.D., and Asch, T.H., 2006, Magnetotelluric Data, Rainier Mesa-Shoshone Mountain, Nevada Test Site, Nevada: U.S. Geological Survey Open-File Report 2006-1215, 256 p

Winograd, I.J. and Thordarson, W., 1975, Hydrogeologic and Hydrochemical Framework, South-Central Great Basin, Nevada-California, with Special Reference to the Nevada Test Site: U.S. Geological Survey Professional Paper 712-C, Washington, D.C., TIC: 206787. 


\section{Appendix A: 2-D Resistivity Models, Apparent Resistivities, and Phase Data}

Appendix A contains, for each profile, the 2-D resistivity models with the forward modeling mesh displayed and the observed and calculated apparent resistivity and phase curves for each station. The models are organized by profile number (1, 2 , 4, 6, and 7) and subdivided by the model number shown in the upper right corner of the 2-D model figure.

Each model is presented in the following order:

a) The 2-D resistivity model (without the mesh and interpretations in figures 3-8);

b) The observed and calculated apparent resistivity sounding curves;

c) The observed and calculated impedance phase curves. 


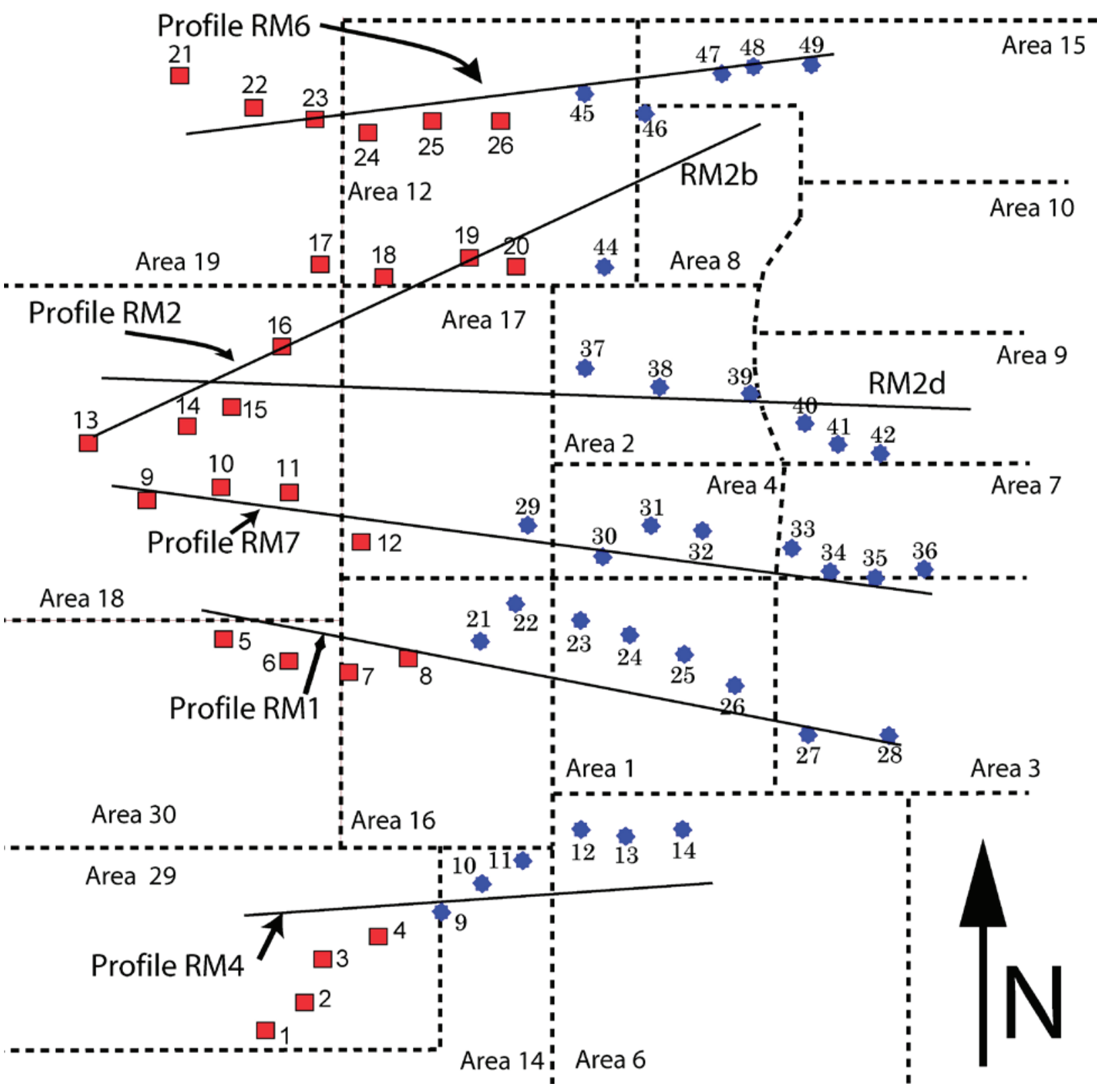

Figure A1. Schematic image showing magnetotelluric (MT) stations in and near Rainier Mesa south to Shoshone Mountain and east to Yucca Flat, Nevada Test Site, Nevada, grouped into six profiles. Approximate azimuth of each profile indicated by solid black lines. MT stations acquired in 2005 are numbered red squares (1-26); 2003 data stations are numbered 9-49 (blue stars). Dashed lines are boundaries of Nevada Test Site Areas 1-4, 6-10, 12-19, 29 , and 30. 


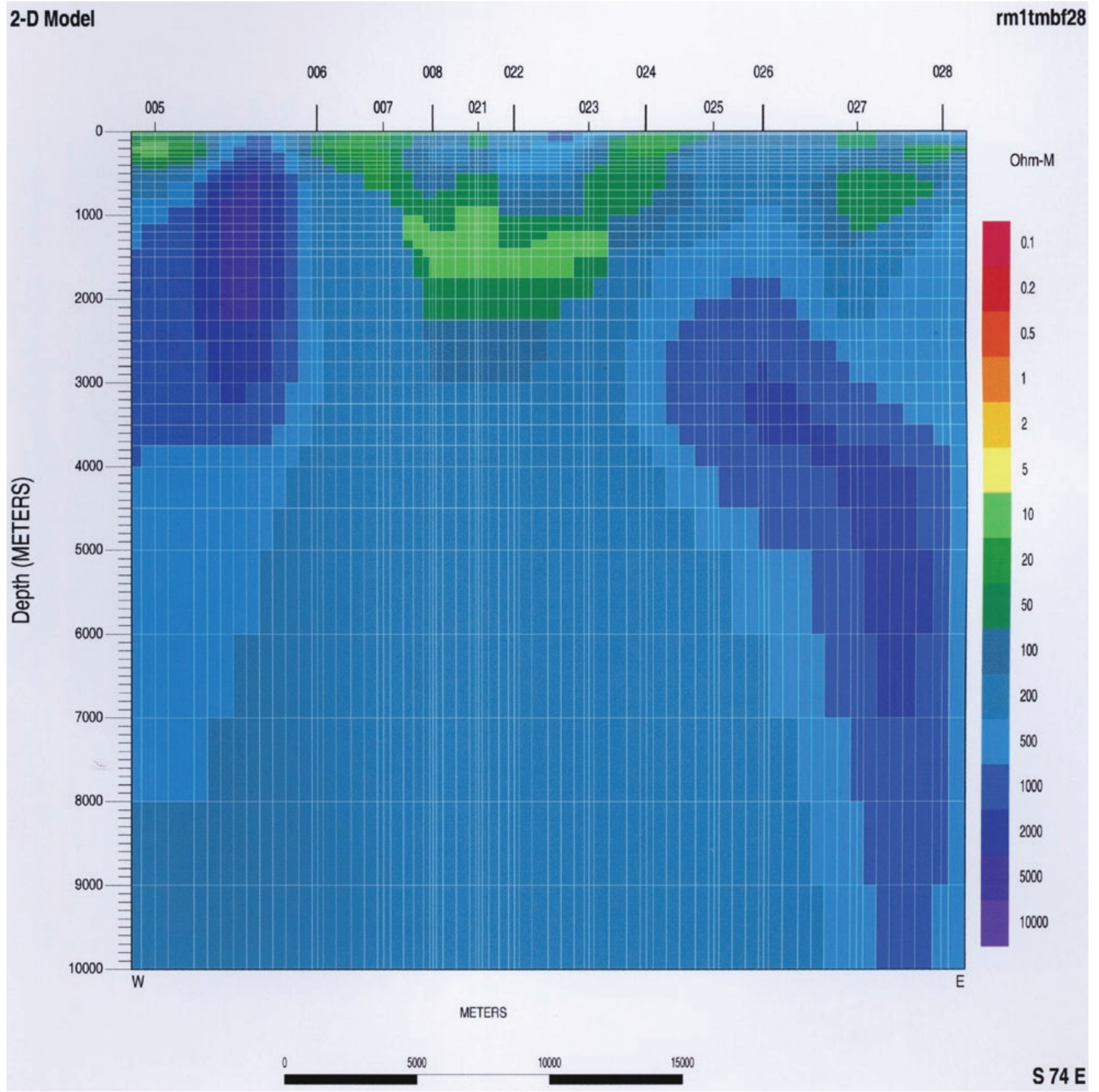

Figure A2. Profile RM1, 2-D resistivity model 28 - depth section with model mesh. 

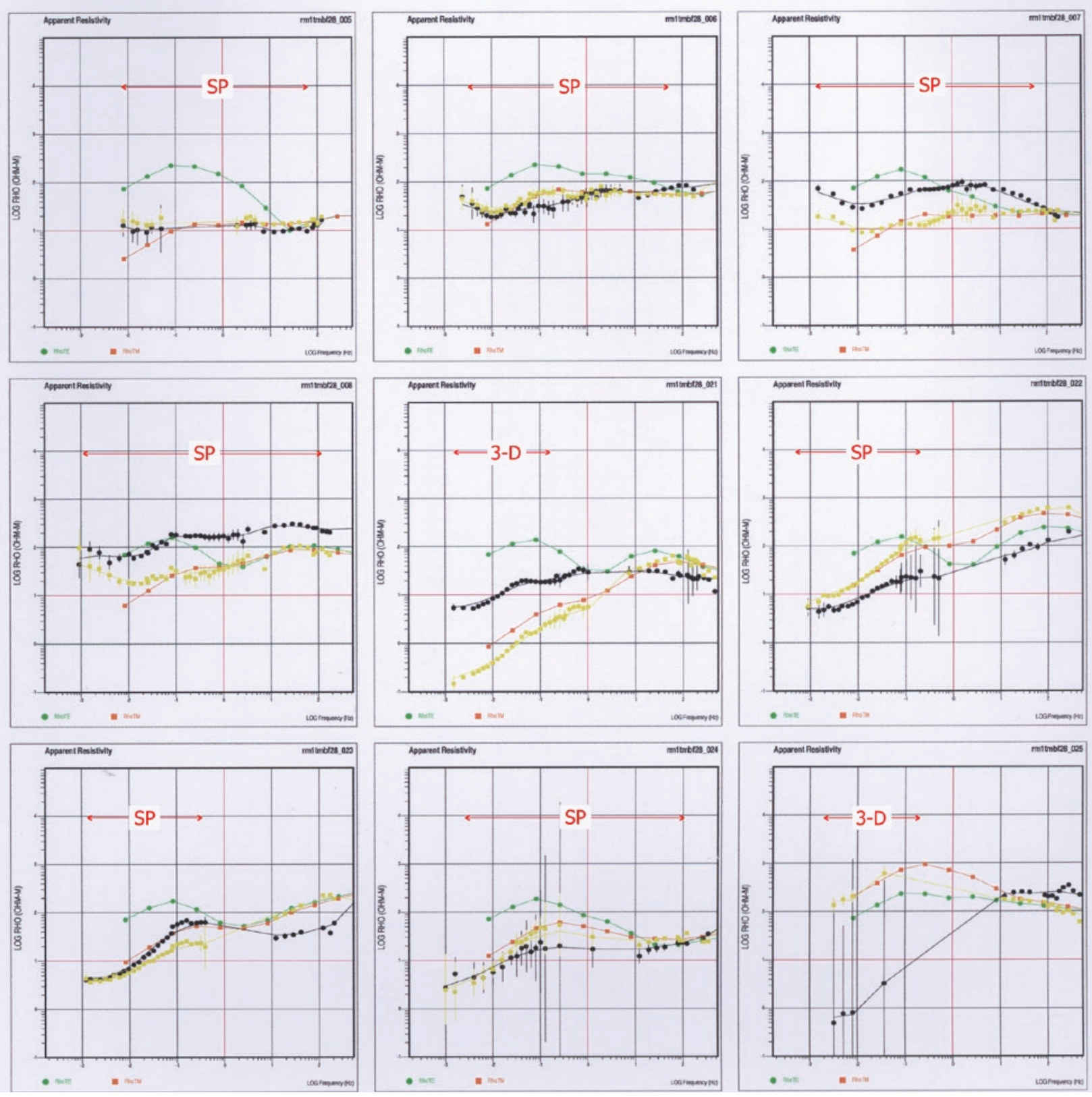

Figure A3a. Profile RM1, 2-D resistivity model 28 - observed (TE-black, TM-yellow) and calculated (TE-green, TM-orange) MT apparent resistivity sounding curves. 3-D label indicates three-dimensional character of electromagnetic response. SP label indicates electrical resistivity structure is sub-parallel to the profile direction. 

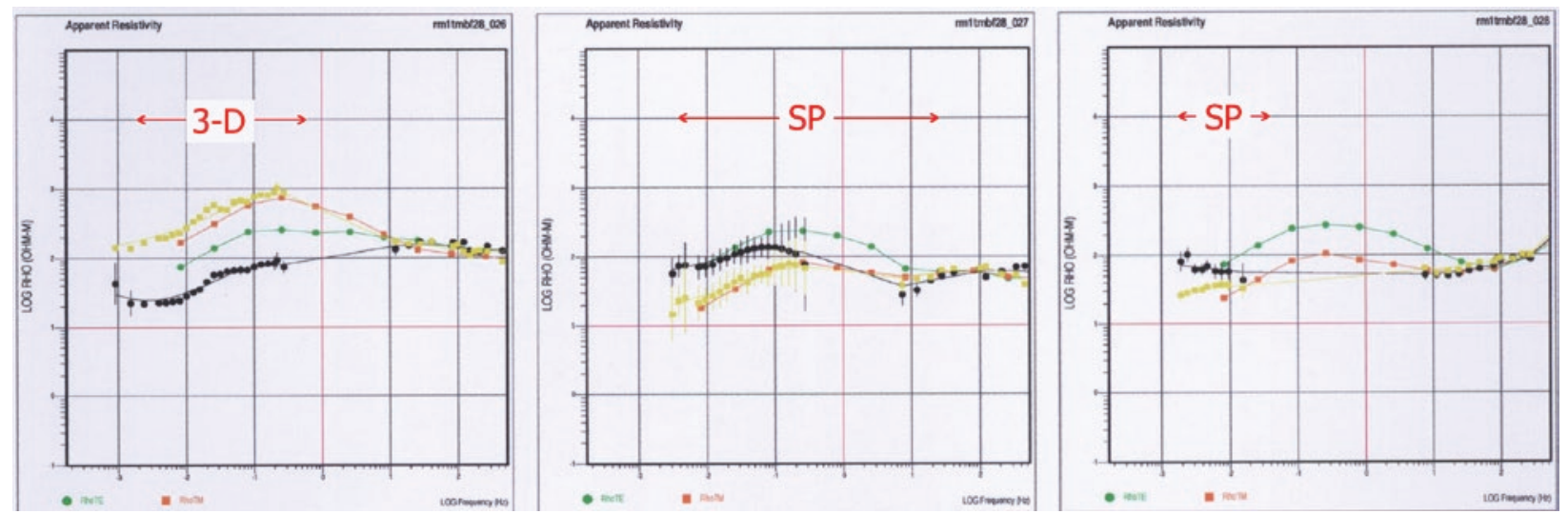

Figure A3b. Profile RM1, 2-D resistivity model 28 - observed (TE-black, TM-yellow) and calculated (TE-green, TM-orange) MT apparent resistivity sounding curves. 3-D label indicates three-dimensional character of electromagnetic response. SP label indicates electrical resistivity structure is sub-parallel to the profile direction. 

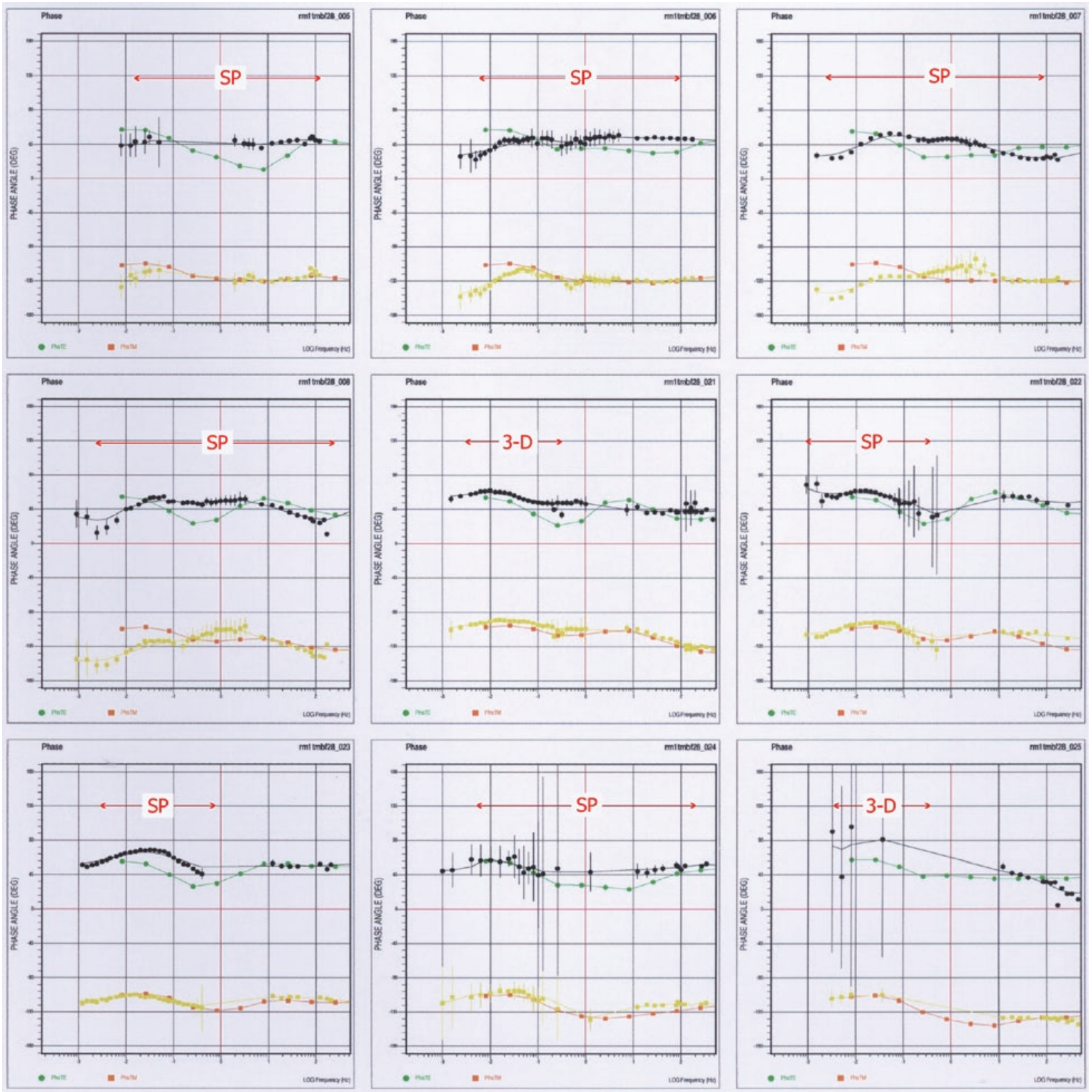

Figure A4a. Profile RM1, 2-D resistivity model 28 - observed (TE-black, TM-yellow) and calculated (TE-green, TM-orange) MT impedance phase curves. 3-D label indicates three-dimensional character of electromagnetic response. SP label indicates electrical resistivity structure is sub-parallel to the profile direction. 

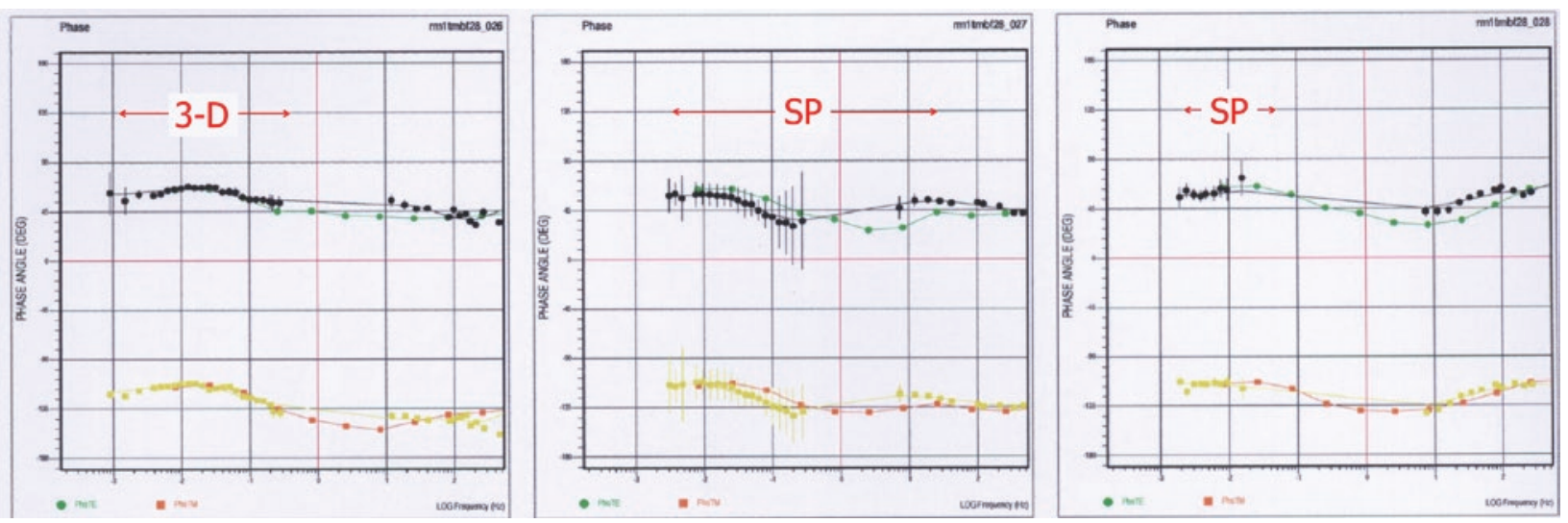

Figure A4b. Profile RM1, 2-D resistivity model 28 - observed (TE-black, TM-yellow) and calculated (TE-green, TM-orange) MT impedance phase curves. 3-D label indicates three-dimensional character of electromagnetic response. SP label indicates electrical resistivity structure is sub-parallel to the profile direction. 


\section{2-D Model}

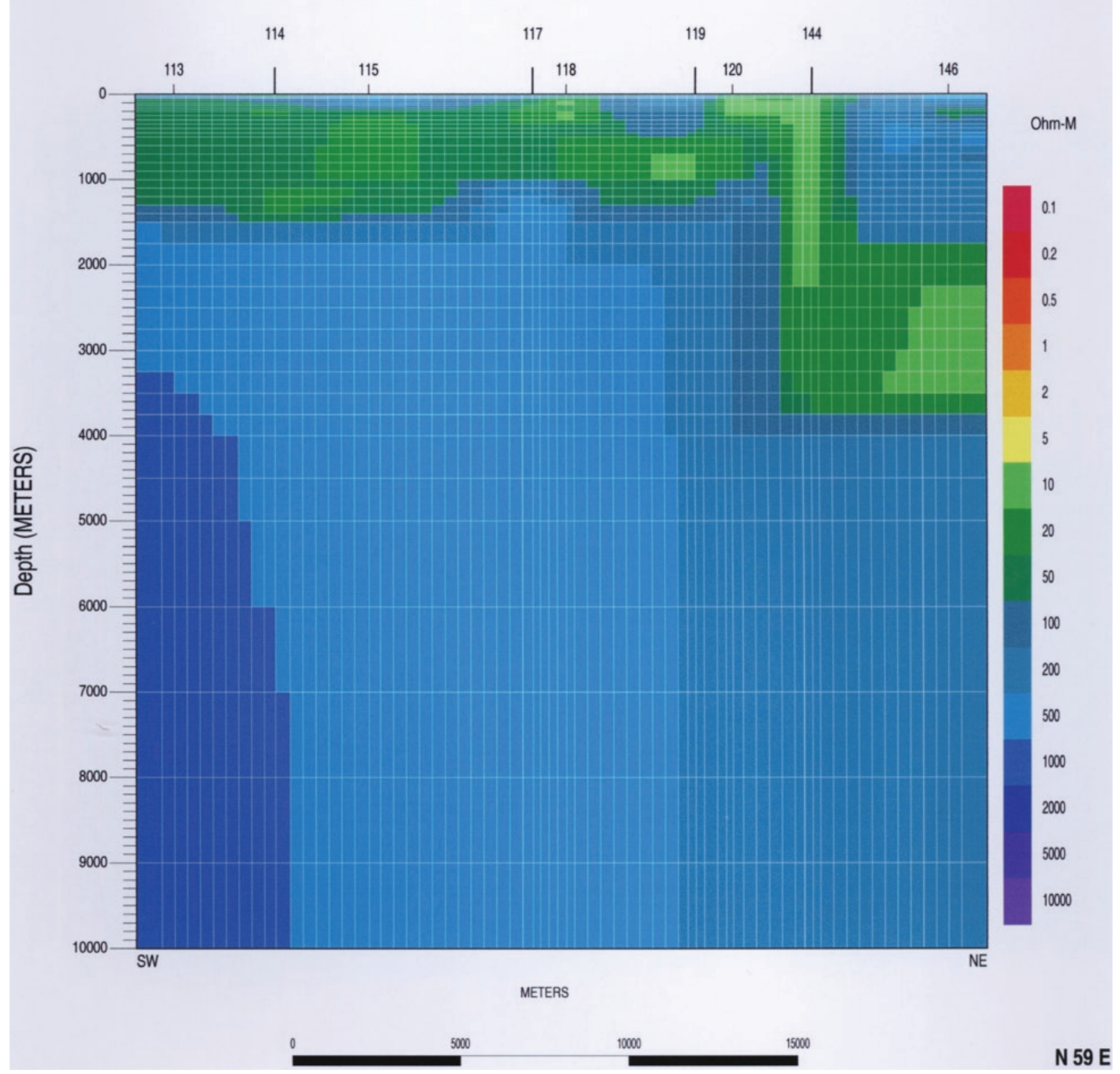

Figure A5. Profile RM2b, 2-D resistivity model 204 - depth section with mesh. 

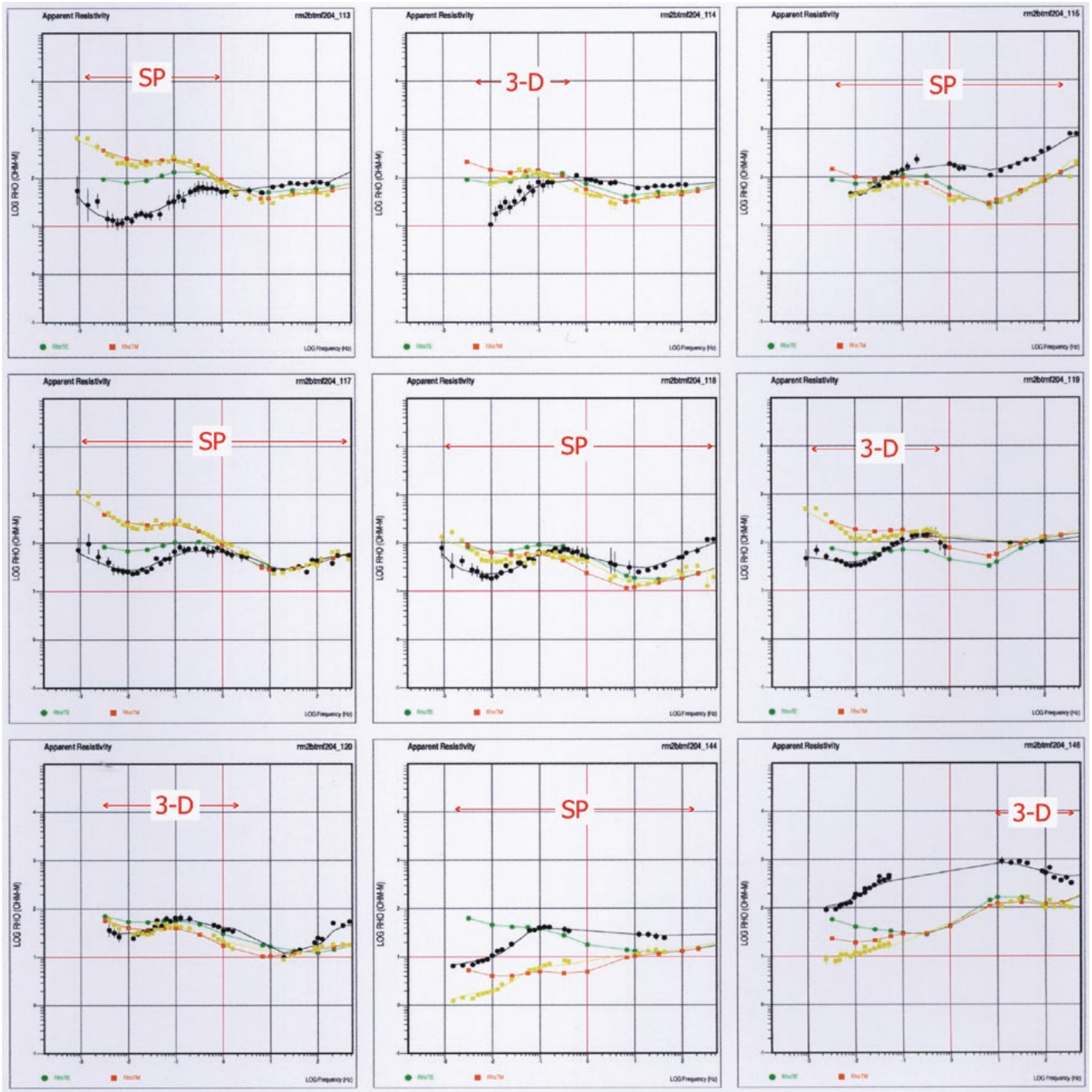

Figure A6. Profile RM2b, 2-D resistivity model 204 - observed (TE-black, TM-yellow) and calculated (TE-green, TM-orange) MT apparent resistivity sounding curves. 3-D label indicates three-dimensional character of electromagnetic response. SP label indicates electrical resistivity structure is sub-parallel to the profile direction. 

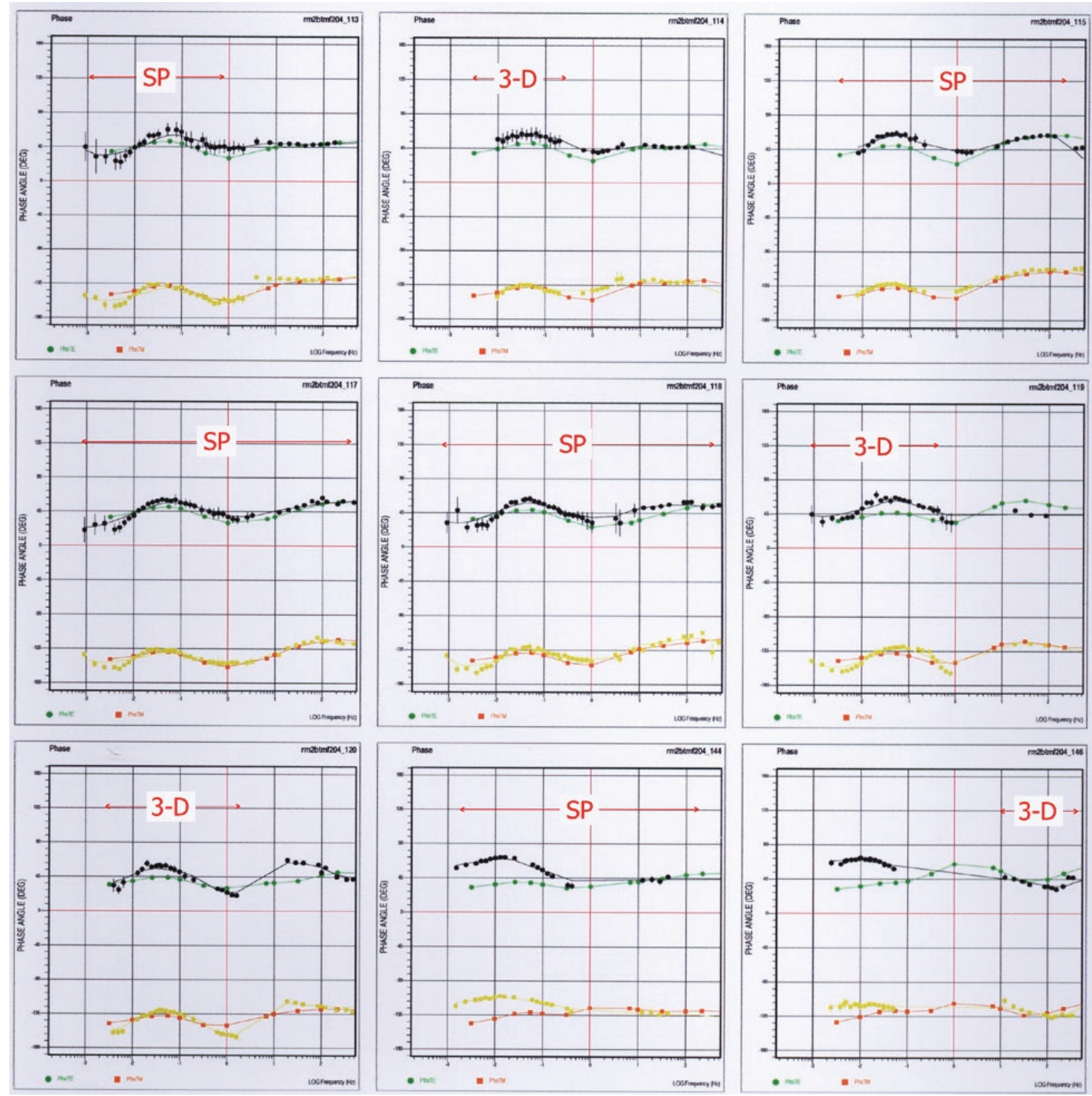

Figure A7. Profile RM2b, 2-D resistivity model 204 - observed (TE-black, TM-yellow) and calculated (TE-green, TM-orange) MT impedance phase curves. 3-D label indicates three-dimensional character of electromagnetic response. SP label indicates electrical resistivity structure is sub-parallel to the profile direction. 
2-D Model

rm2dtmf43
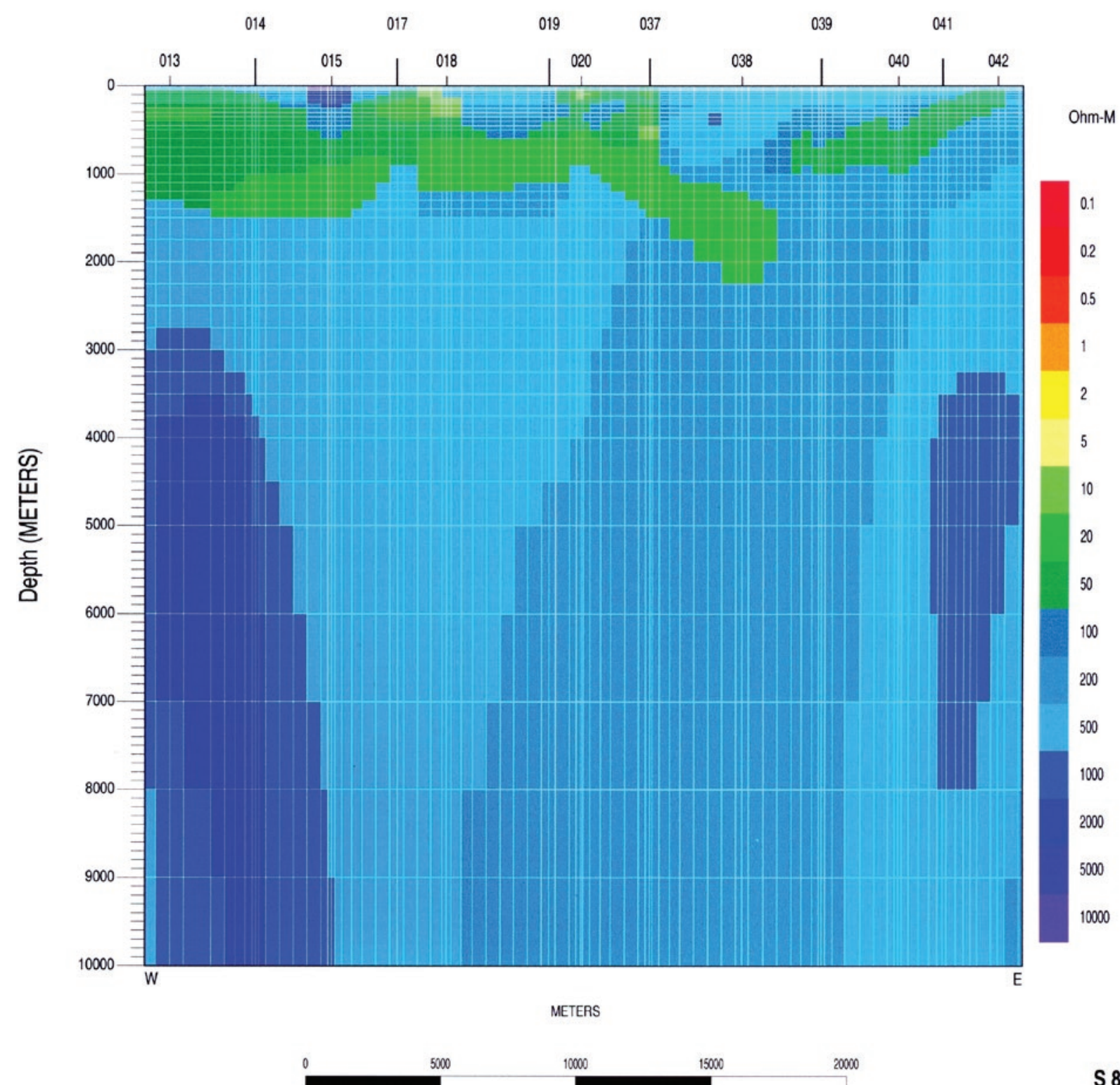

Figure A8. Profile RM2d, 2-D resistivity model 43 - depth section with model mesh. 

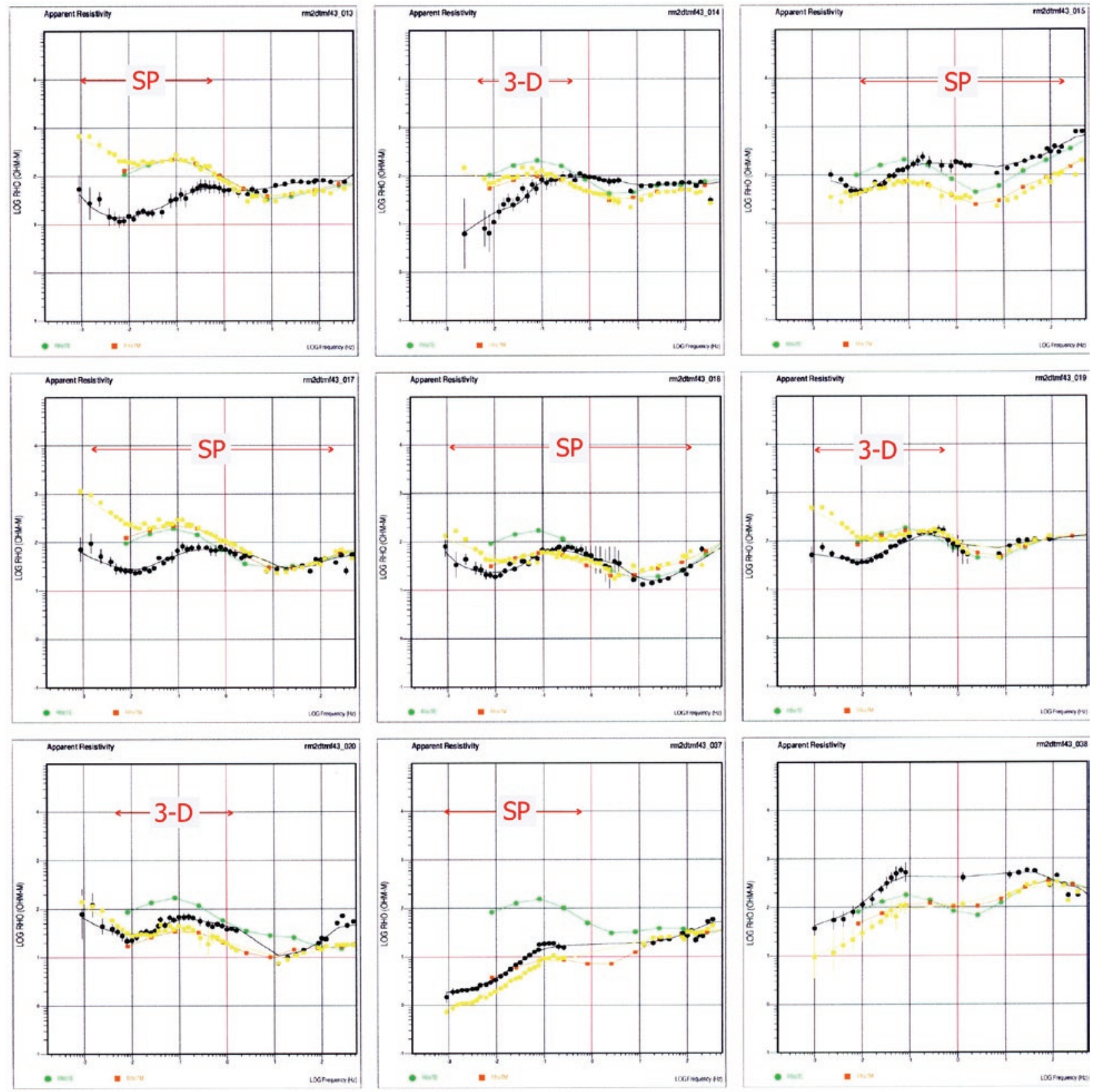

Figure A9a. Profile RM2d, 2-D resistivity model 43 - observed (TE-black, TM-yellow) and calculated (TE-green, TM-orange) MT apparent resistivity sounding curves. 3-D label indicates three-dimensional character of electromagnetic response. SP label indicates electrical resistivity structure is sub-parallel to the profile direction. 

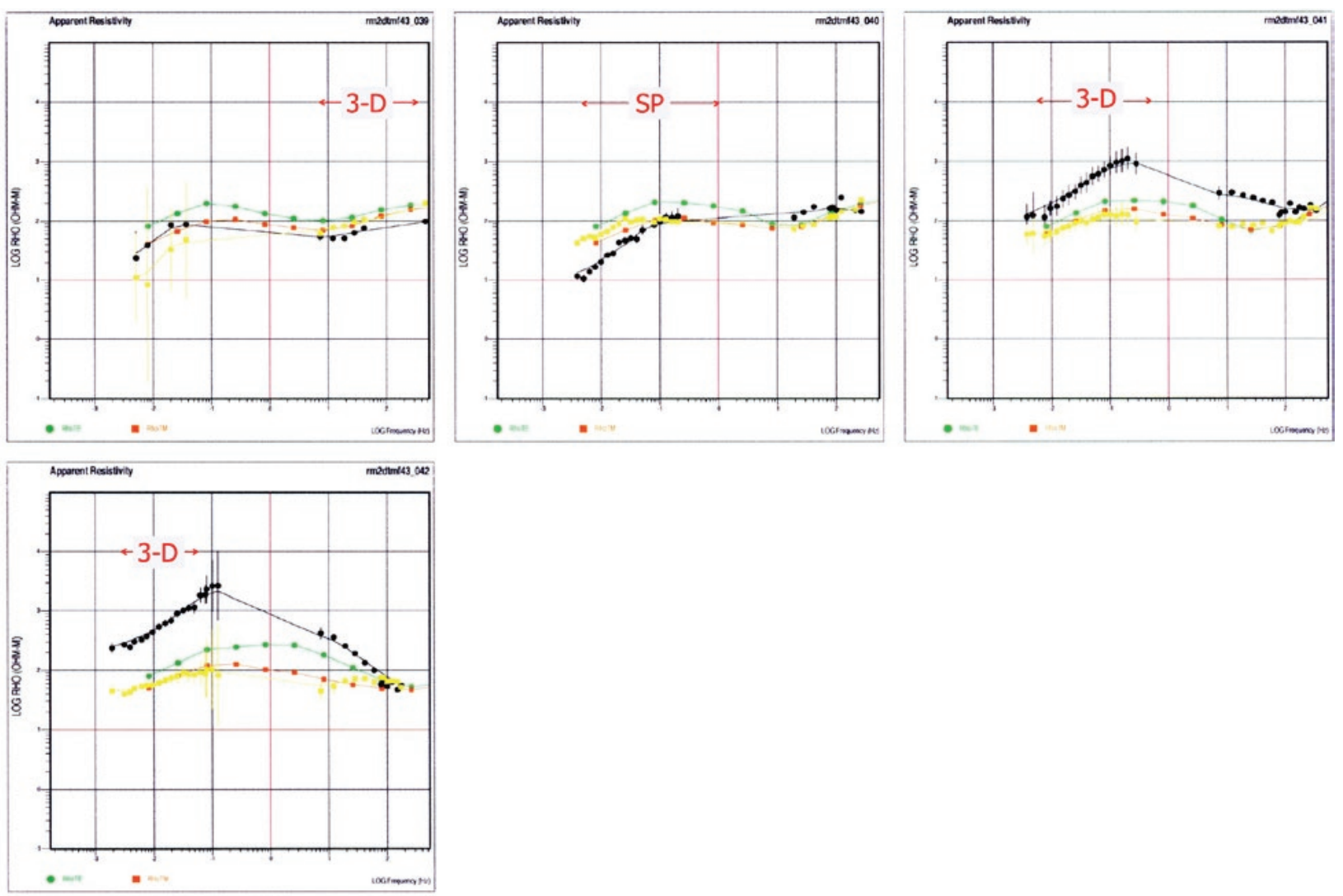

Figure A9b. Profile RM2d, 2-D resistivity model 43 - observed (TE-black, TM-yellow) and calculated (TE-green, TM-orange) MT apparent resistivity sounding curves. 3-D label indicates three-dimensional character of electromagnetic response. SP label indicates electrical resistivity structure is sub-parallel to the profile direction. 

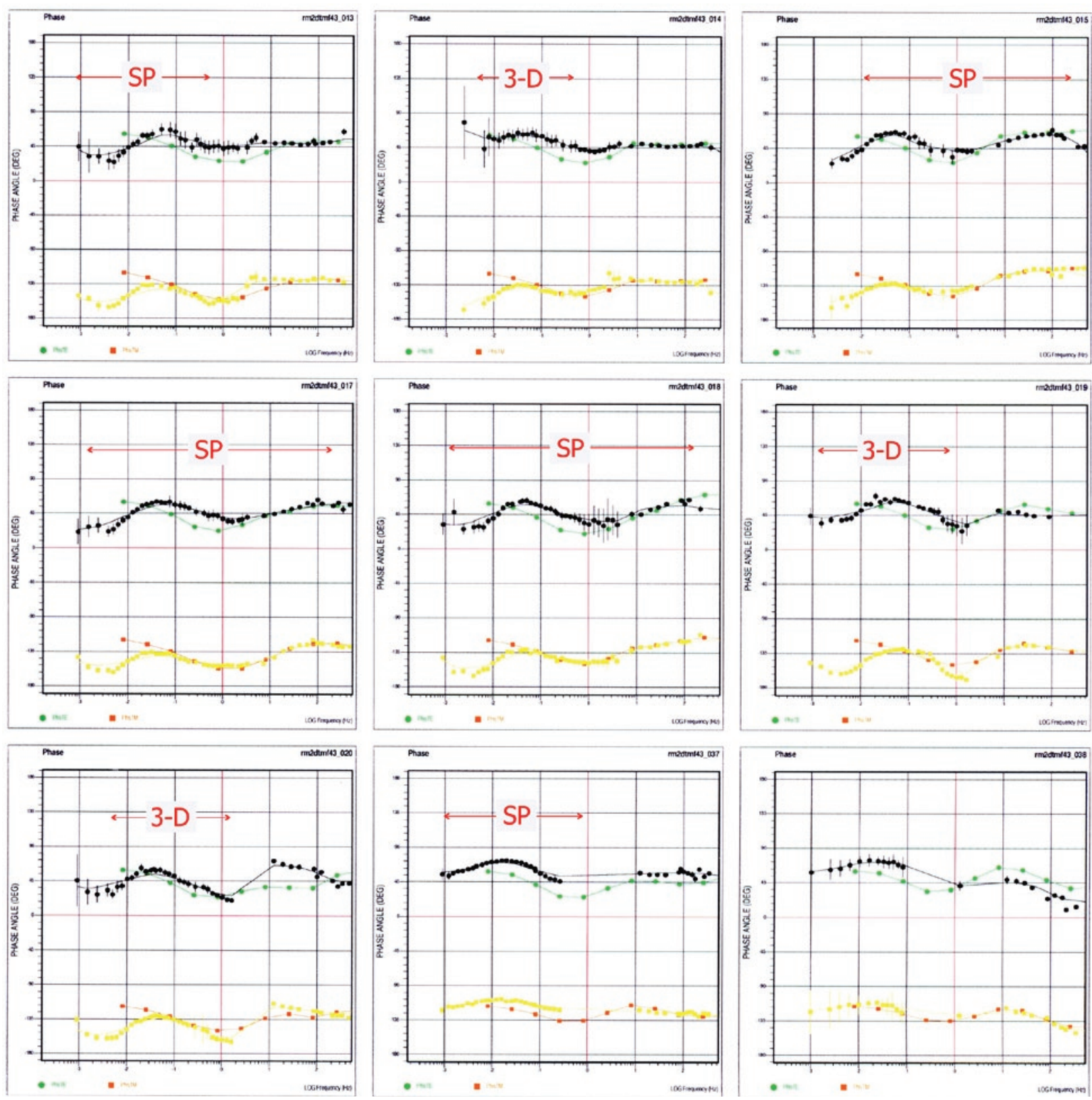

Figure A10a. Profile RM2d, 2-D resistivity model 43 - observed (TE-black, TM-yellow) and calculated (TE-green, TM-orange) MT impedance phase curves. 3-D label indicates three-dimensional character of electromagnetic response. $\mathrm{SP}$ label indicates electrical resistivity structure is sub-parallel to the profile direction. 

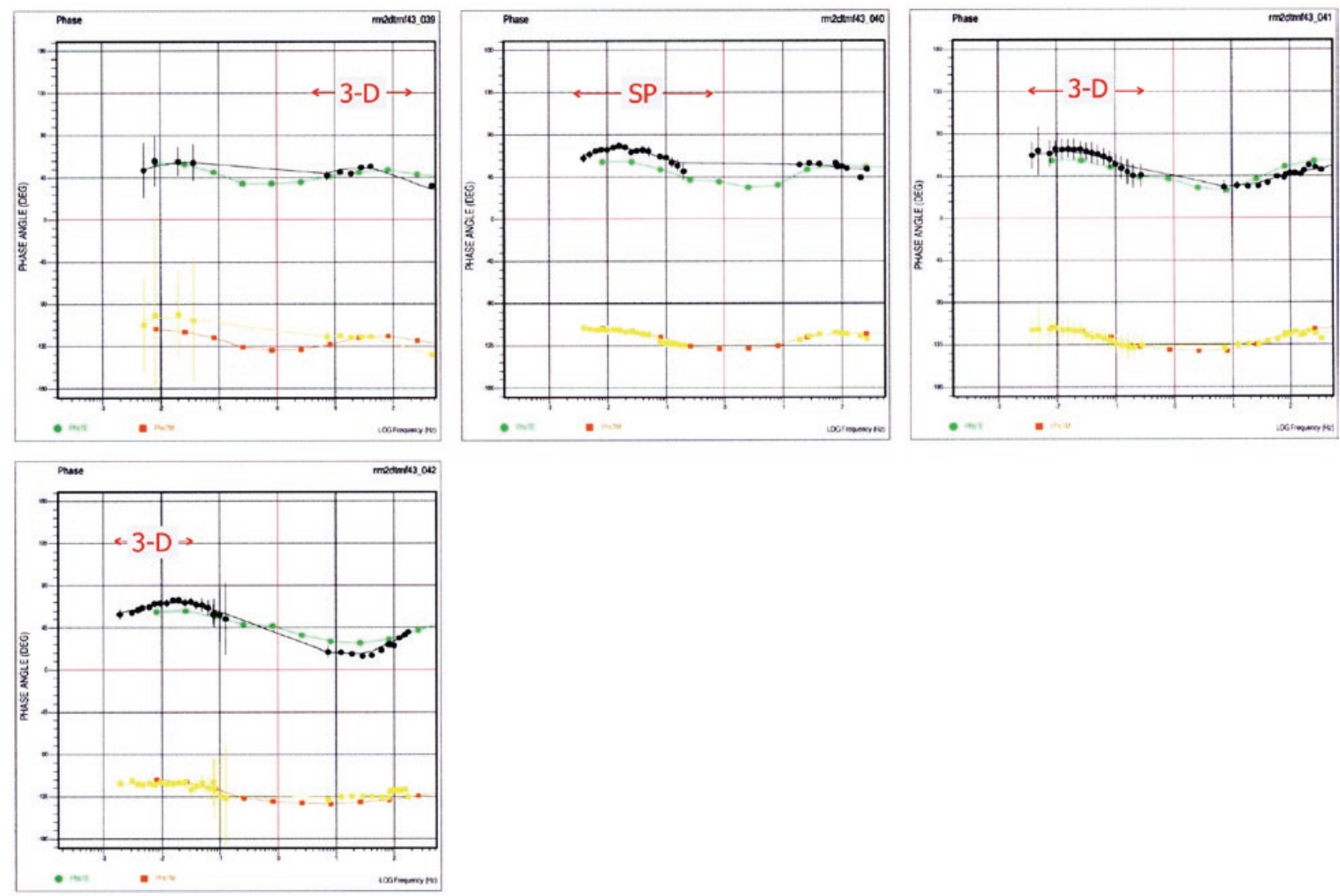

Figure A10b. Profile RM2d, 2-D resistivity model 43 - observed (TE-black, TM-yellow) and calculated (TE-green, TM-orange) MT impedance phase curves. 3-D label indicates three-dimensional character of electromagnetic response. SP label indicates electrical resistivity structure is sub-parallel to the profile direction. 


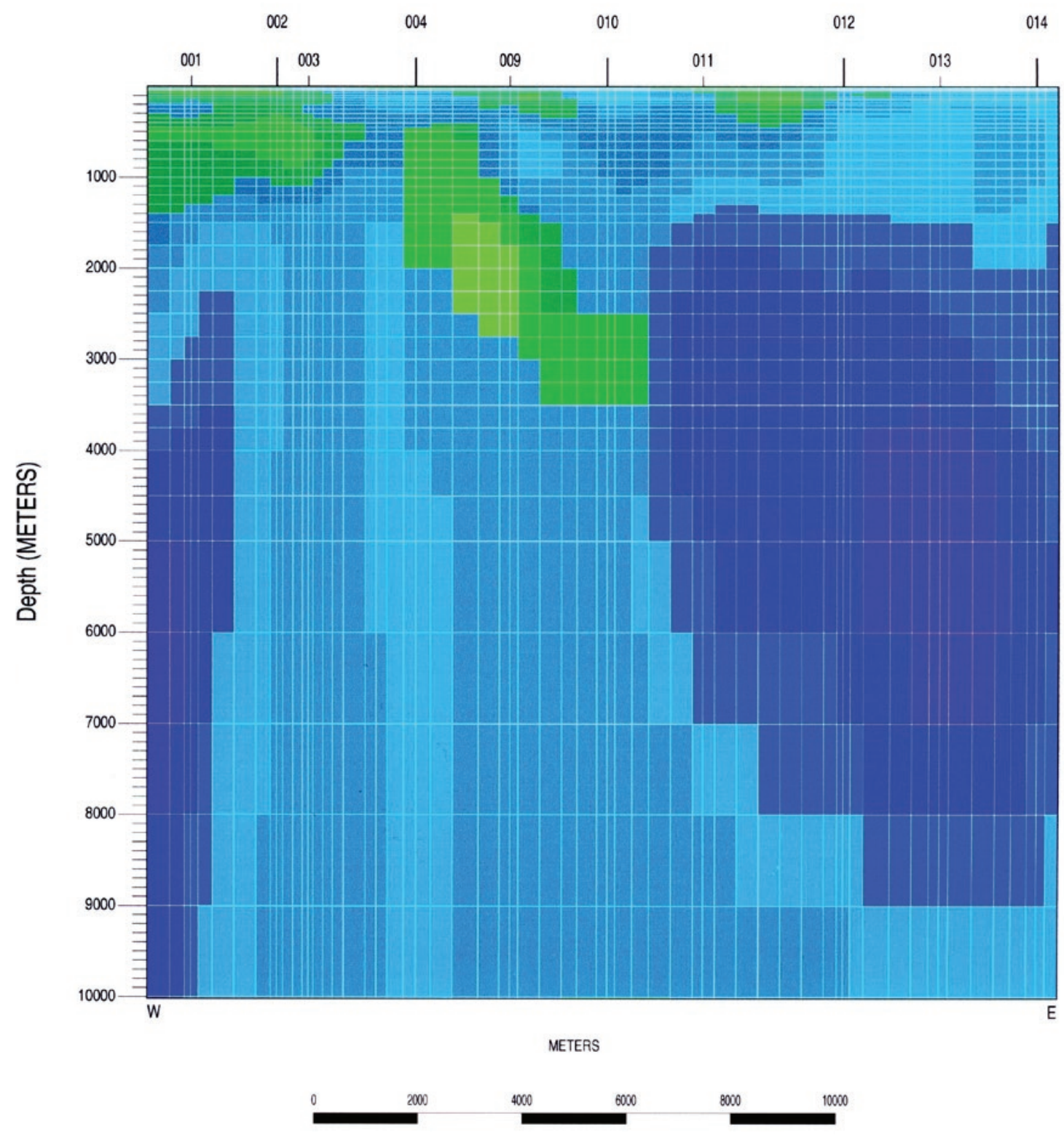

Ohm-M

0.1

02

0.5

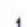

2

5

10

20

50

100

200

Figure A11. Profile RM4, 2-D resistivity model 28 - depth section with model mesh. 

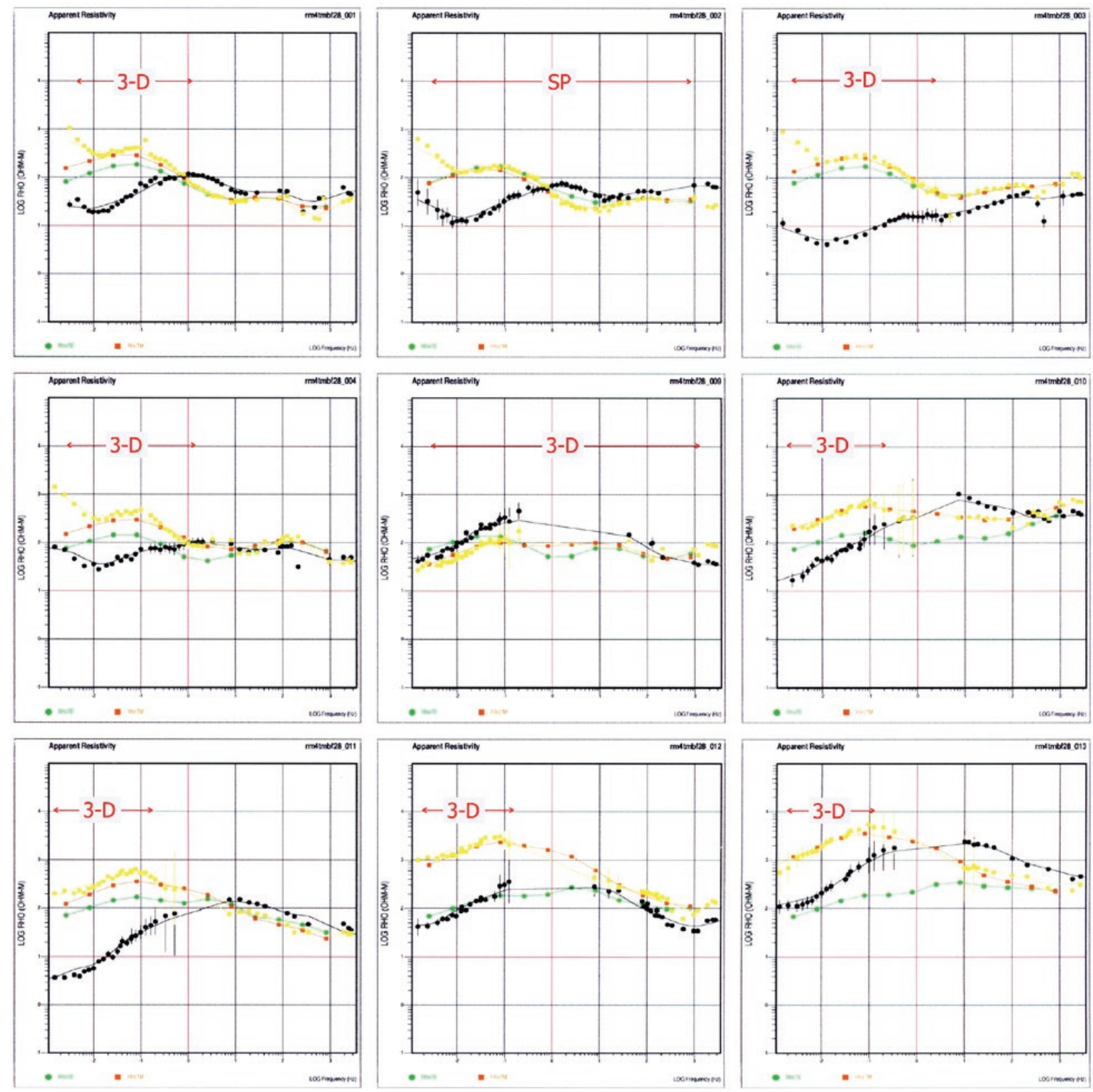

Figure A12a. Profile 2, 2-D resistivity model 48 - observed (TE-black, TM-yellow) and calculated (TE-green, TM-orange) MT apparent resistivity sounding curves. 3-D label indicates three-dimensional character of electromagnetic response. SP label indicates electrical resistivity structure is sub-parallel to the profile direction. 


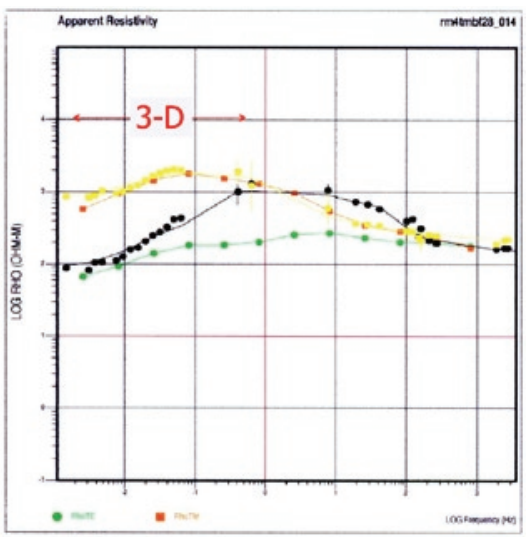

Figure A12b. Profile 2, 2-D resistivity model 48 - observed (TE-black, TM-yellow) and calculated (TE-green, TM-orange) MT apparent resistivity sounding curves. 3-D label indicates three-dimensional character of electromagnetic response. SP label indicates electrical resistivity structure is sub-parallel to the profile direction. 

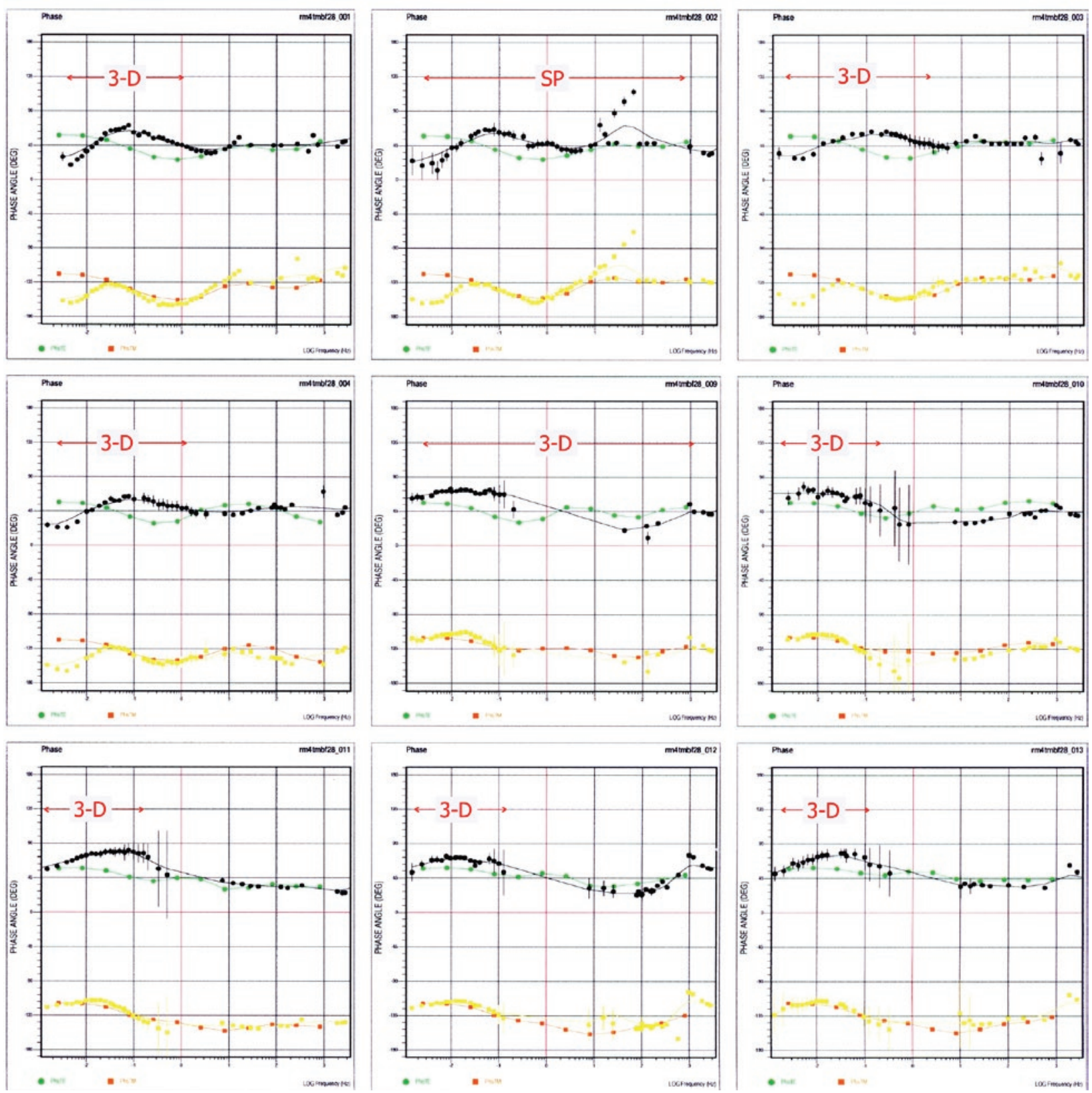

Figure A13a. Profile 2, 2-D resistivity model 48 - observed (TE-black, TM-yellow) and calculated (TE-green, TM-orange) MT impedance phase curves. 3-D label indicates three-dimensional character of electromagnetic response. SP label indicates electrical resistivity structure is sub-parallel to the profile direction. 


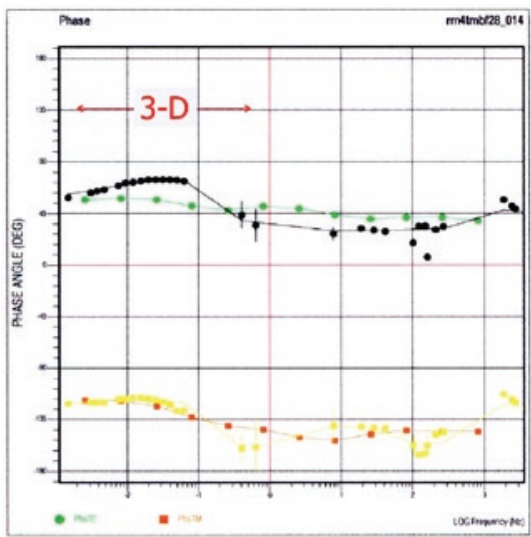

Figure A13b. Profile 2, 2-D resistivity model 48 - observed (TE-black, TM-yellow) and calculated (TE-green, TM-orange) MT impedance phase curves. 3-D label indicates three-dimensional character of electromagnetic response. SP label indicates electrical resistivity structure is sub-parallel to the profile direction. 
2-D Model

rm6btmf57
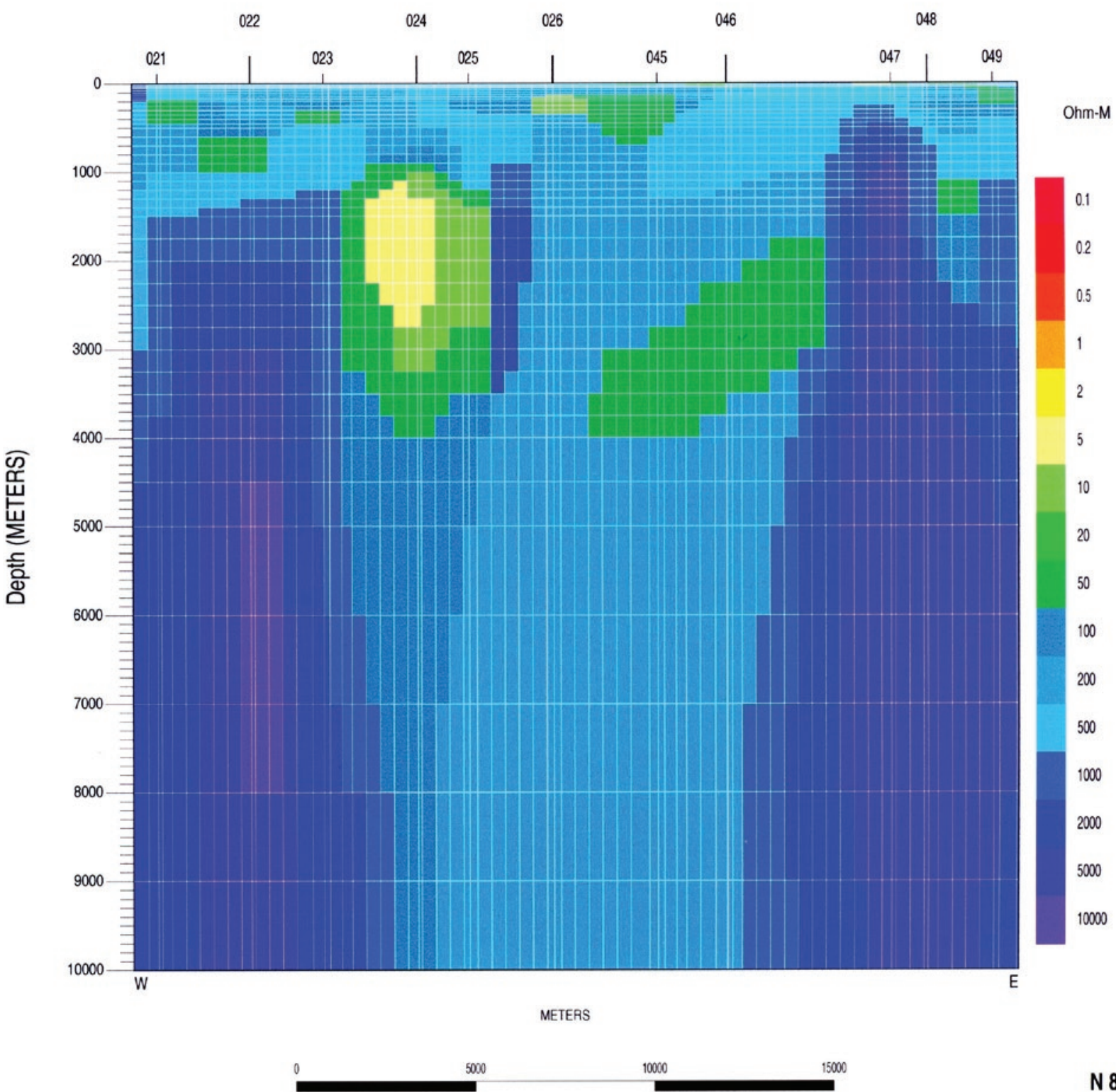

N 81 E

Figure A14. Profile RM6, 2-D resistivity model 57 - depth section with model mesh. 

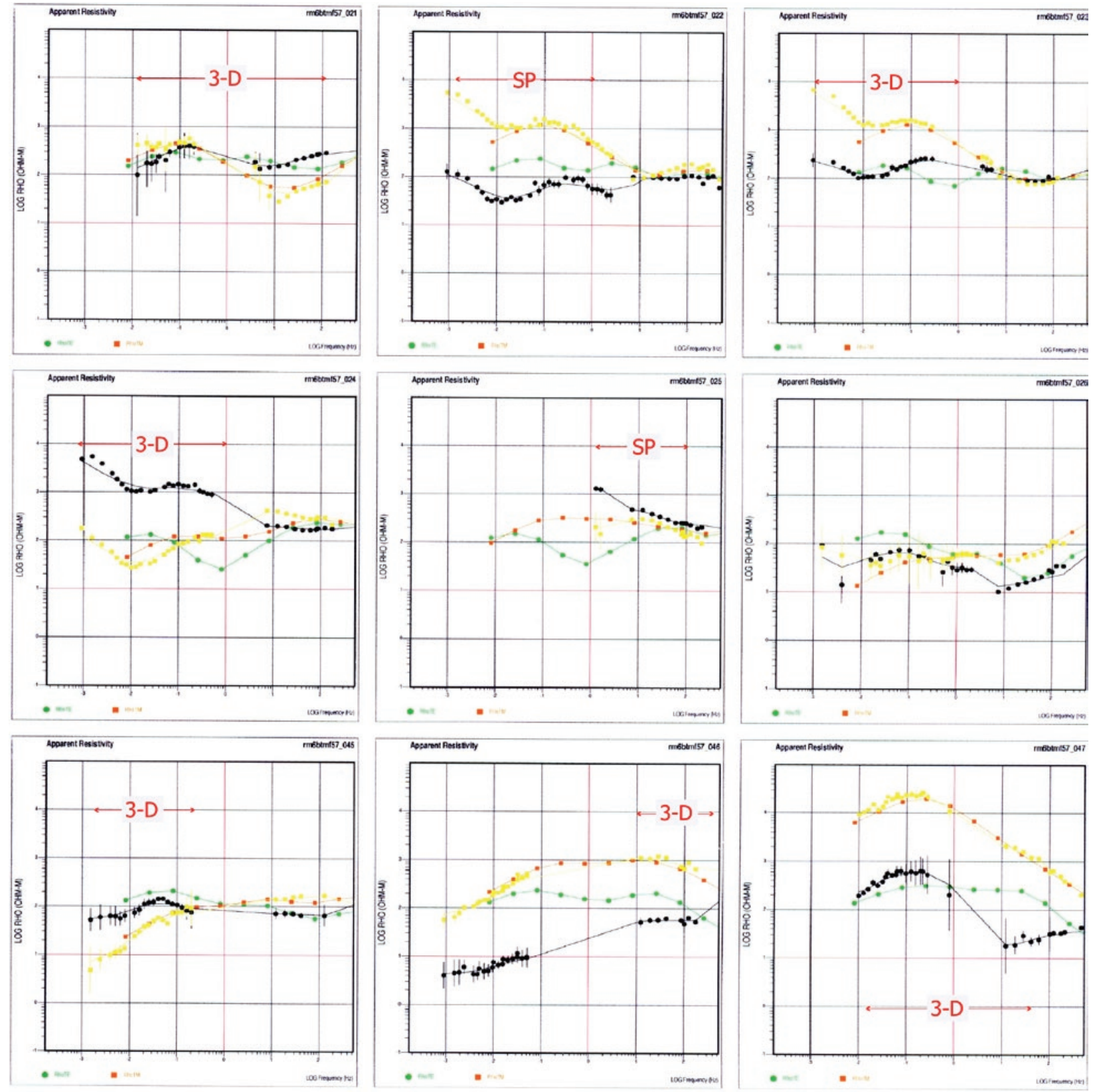

Figure A15a. Profile RM6, 2-D resistivity model 57 - observed (TE-black, TM-yellow) and calculated (TE-green, TM-orange) MT apparent resistivity sounding curves. 3-D label indicates three-dimensional character of electromagnetic response. SP label indicates electrical resistivity structure is sub-parallel to the profile direction. 

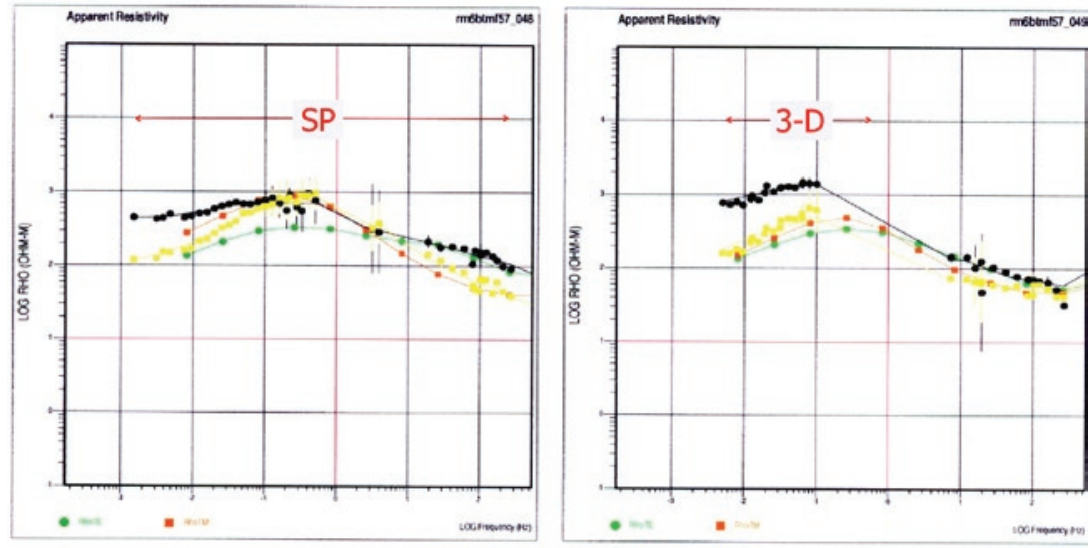

Figure A15b. Profile RM6, 2-D resistivity model 57 - observed (TE-black, TM-yellow) and calculated (TE-green, TM-orange) MT apparent resistivity sounding curves. 3-D label indicates three-dimensional character of electromagnetic response. SP label indicates electrical resistivity structure is sub-parallel to the profile direction. 

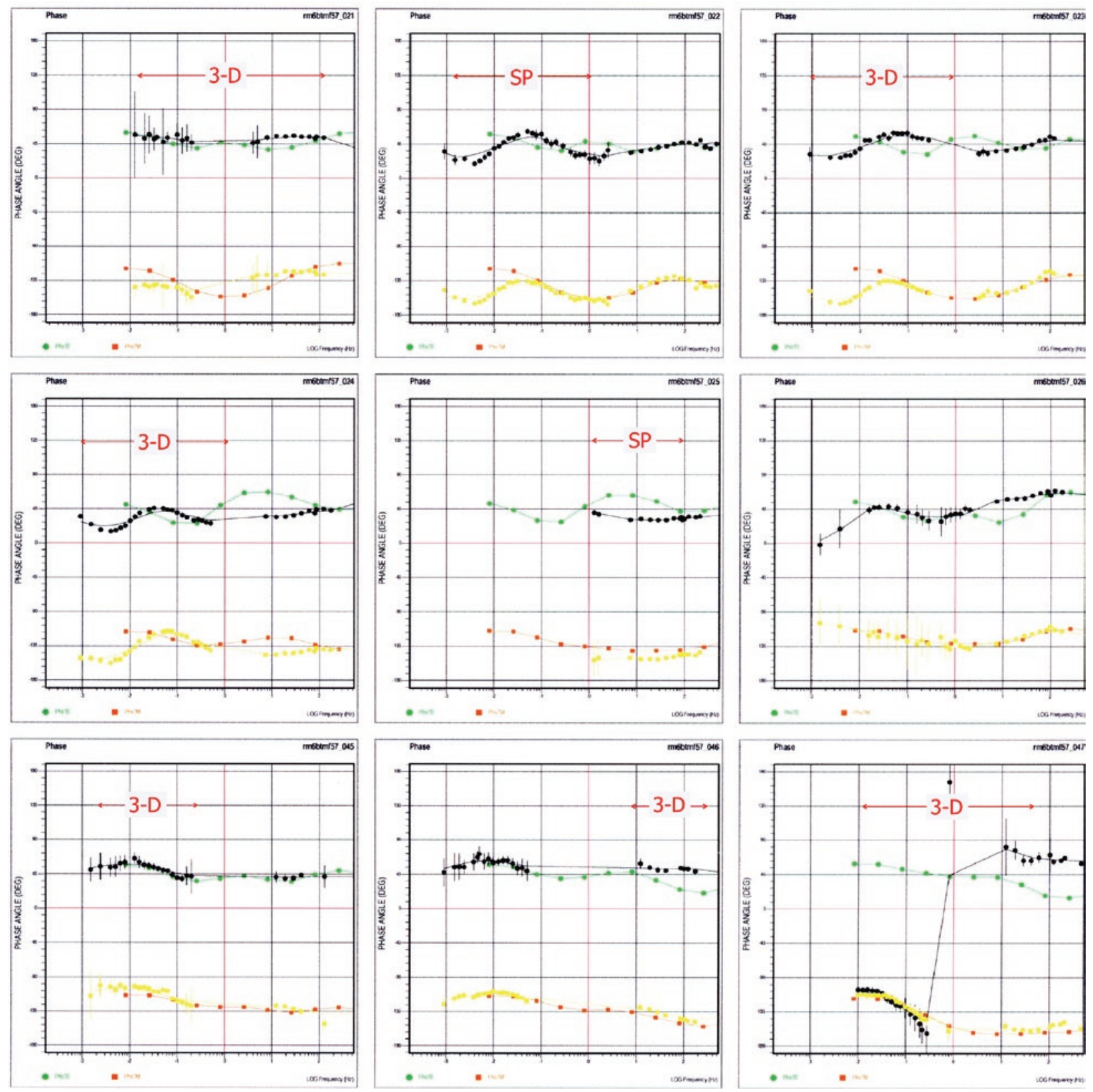

Figure A16a. Profile RM6, 2-D resistivity model 57- observed (TE-black, TM-yellow) and calculated (TE-green, TM-orange) MT impedance phase curves. 3-D label indicates three-dimensional character of electromagnetic response. SP label indicates electrical resistivity structure is sub-parallel to the profile direction. 

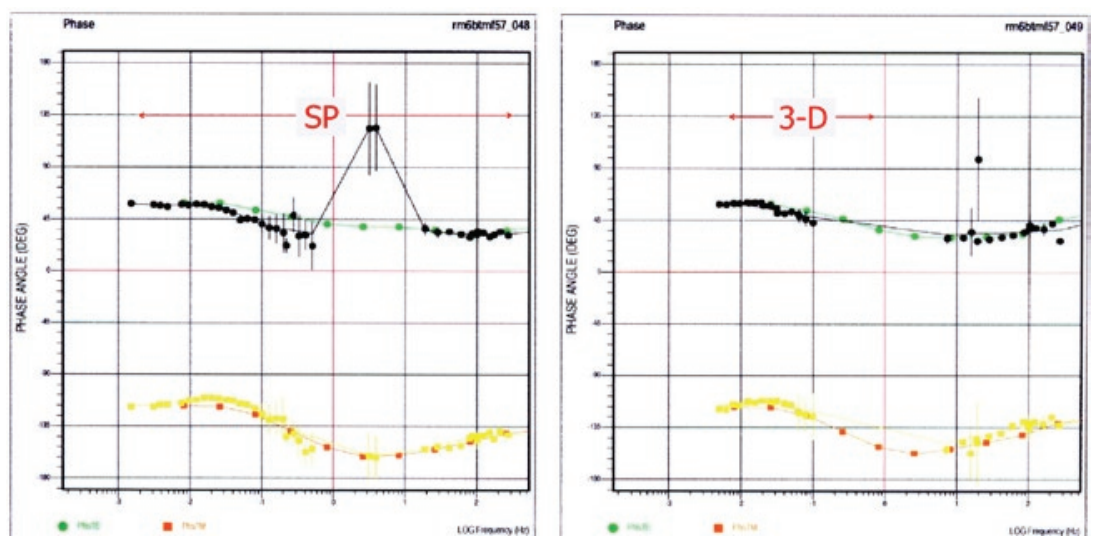

Figure A16b. Profile RM6, 2-D resistivity model 57- observed (TE-black, TM-yellow) and calculated (TE-green, TM-orange) MT impedance phase curves. 3-D label indicates three-dimensional character of electromagnetic response. SP label indicates electrical resistivity structure is sub-parallel to the profile direction. 
2-D Model

rm7tmbf44
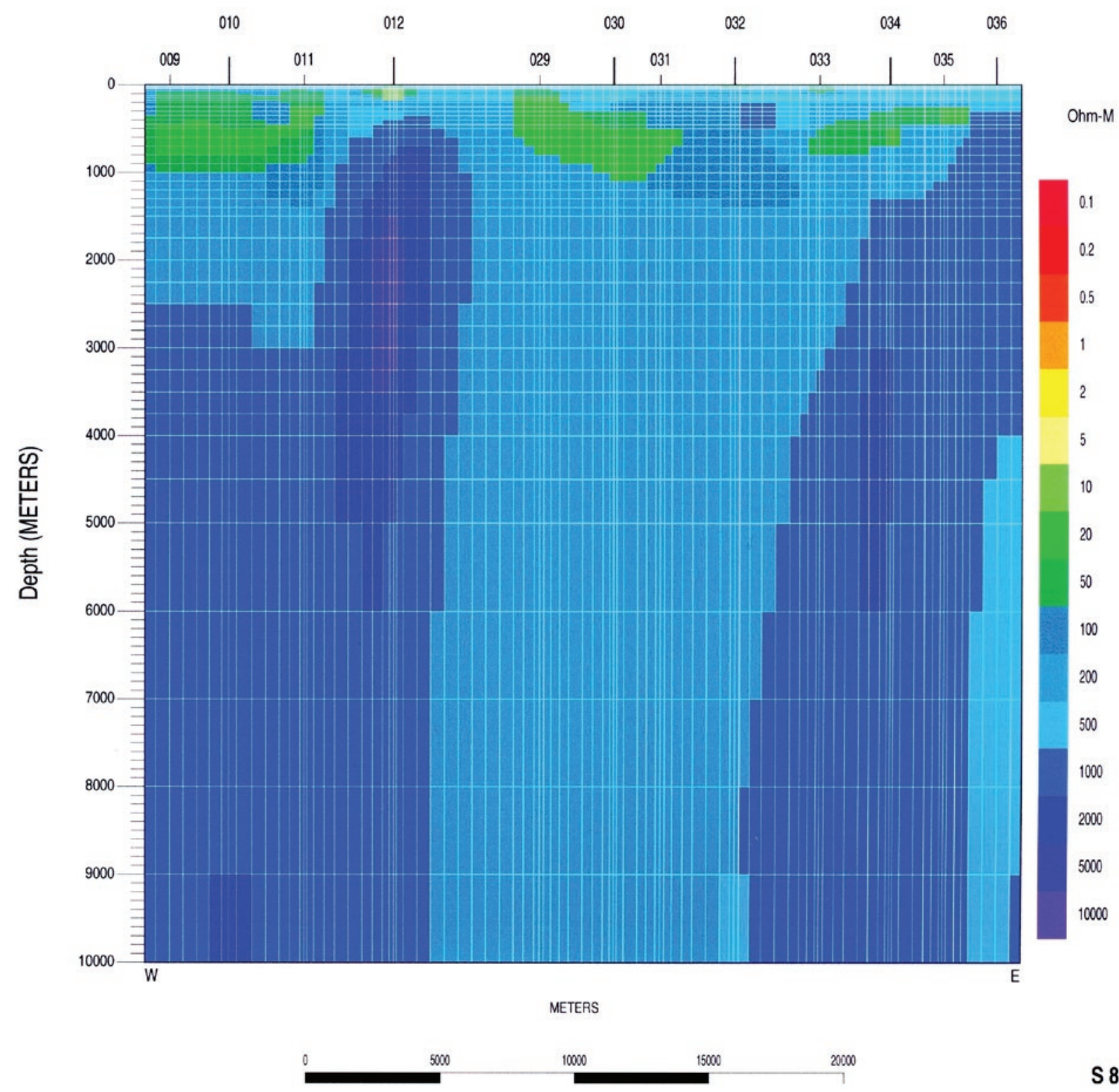

Figure A17. Profile RM7, 2-D resistivity model 44 - depth section with model mesh. 

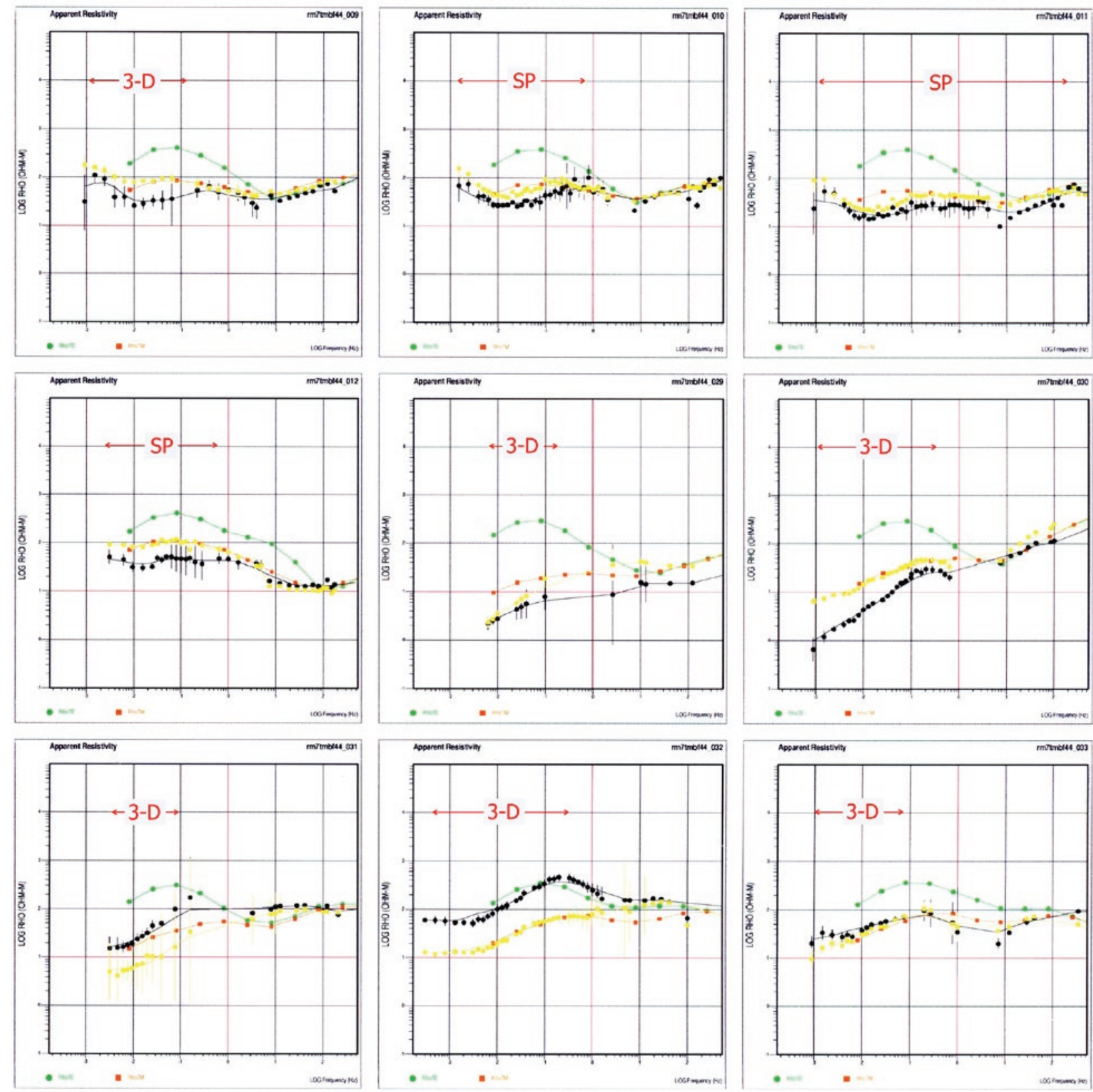

Figure A18a. Profile RM7, 2-D resistivity model 44 - observed (TE-black, TM-yellow) and calculated (TE-green, TM-orange) MT apparent resistivity sounding curves. 3-D label indicates three-dimensional character of electromagnetic response. SP label indicates electrical resistivity structure is sub-parallel to the profile direction. 

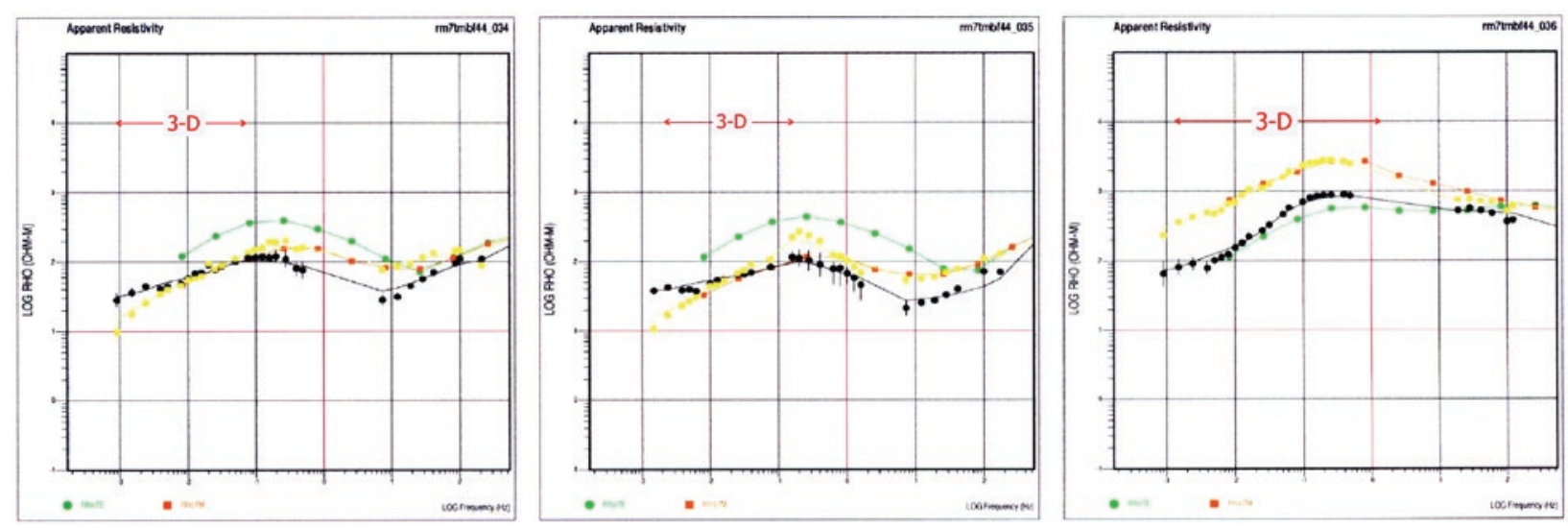

Figure A18b. Profile RM7, 2-D resistivity model 44 - observed (TE-black, TM-yellow) and calculated (TE-green, TM-orange) MT apparent resistivity sounding curves. 3-D label indicates three-dimensional character of electromagnetic response. SP label indicates electrical resistivity structure is sub-parallel to the profile direction. 

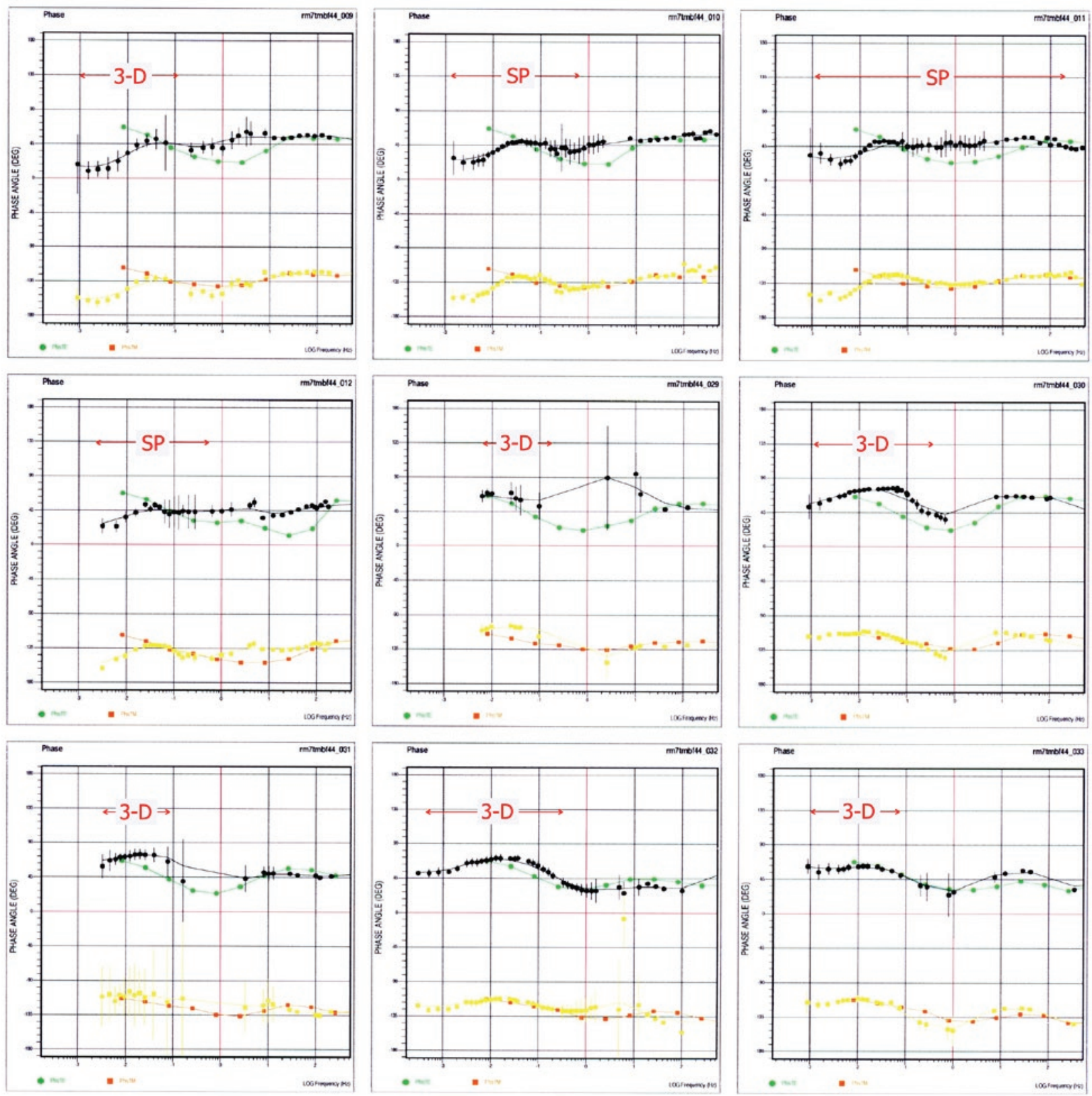

Figure A19a. Profile RM7, 2-D resistivity model 44 - observed (TE-black, TM-yellow) and calculated (TE-green, TM-orange) MT impedance phase curves. 3-D label indicates three-dimensional character of electromagnetic response. SP label indicates electrical resistivity structure is sub-parallel to the profile direction. 

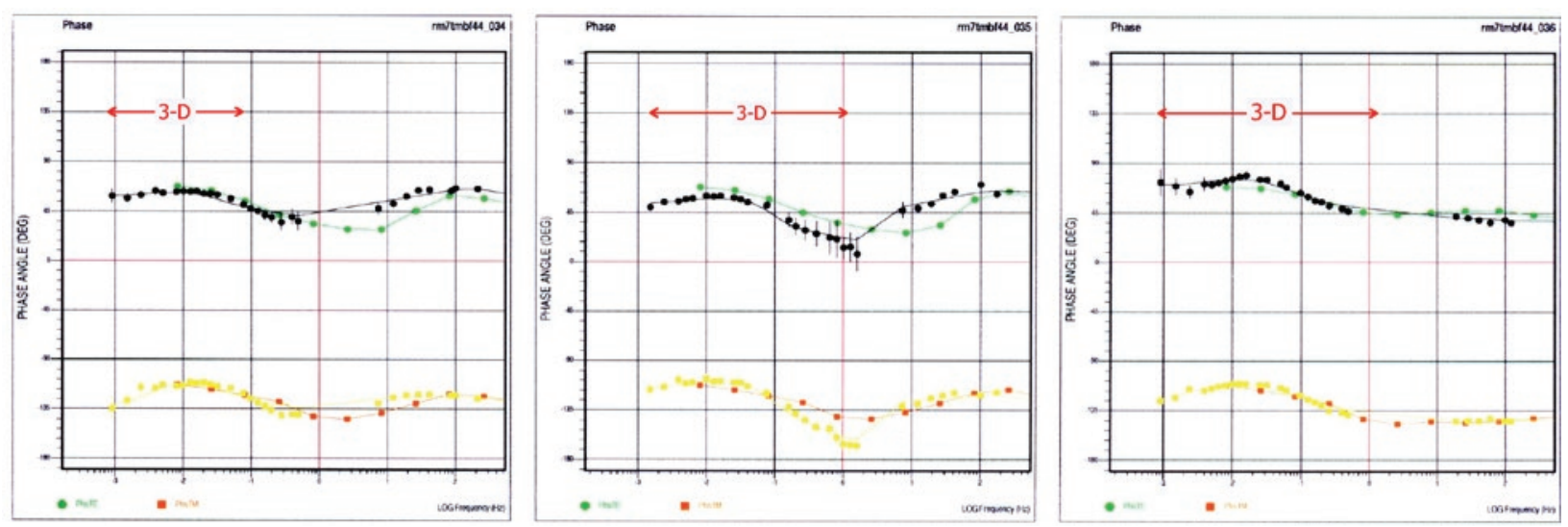

Figure A19b. Profile RM7, 2-D resistivity model 44 - observed (TE-black, TM-yellow) and calculated (TE-green, TM-orange) MT impedance phase curves. 3-D label indicates three-dimensional character of electromagnetic response. SP label indicates electrical resistivity structure is sub-parallel to the profile direction 